\title{
Metabolism and biomarkers of heterocyclic aromatic amines in humans
}

\author{
Medjda Bellamri ${ }^{1,2}$, Scott J. Walmsley ${ }^{1,3}$ and Robert J. Turesky ${ }^{1,2^{*}}$ (D)
}

\begin{abstract}
Heterocyclic aromatic amines (HAAs) form during the high-temperature cooking of meats, poultry, and fish. Some HAAs also arise during the combustion of tobacco. HAAs are multisite carcinogens in rodents, inducing cancer of the liver, gastrointestinal tract, pancreas, mammary, and prostate glands. HAAs undergo metabolic activation by Nhydroxylation of the exocyclic amine groups to produce the proposed reactive intermediate, the heteroaryl nitrenium ion, which is the critical metabolite implicated in DNA damage and genotoxicity. Humans efficiently convert HAAs to these reactive intermediates, resulting in HAA protein and DNA adduct formation. Some epidemiologic studies have reported an association between frequent consumption of well-done cooked meats and elevated cancer risk of the colorectum, pancreas, and prostate. However, other studies have reported no associations between cooked meat and these cancer sites. A significant limitation in epidemiology studies assessing the role of HAAs and cooked meat in cancer risk is their reliance on food frequency questionnaires (FFQ) to gauge HAA exposure. FFQs are problematic because of limitations in self-reported dietary history accuracy, and estimating HAA intake formed in cooked meats at the parts-per-billion level is challenging. There is a critical need to establish long-lived biomarkers of HAAs for implementation in molecular epidemiology studies designed to assess the role of HAAs in health risk. This review article highlights the mechanisms of HAA formation, mutagenesis and carcinogenesis, the metabolism of several prominent HAAs, and the impact of critical xenobiotic-metabolizing enzymes on biological effects. The analytical approaches that have successfully biomonitored HAAs and their biomarkers for molecular epidemiology studies are presented.
\end{abstract}

Keywords: Heterocyclic aromatic amines, Mutagens, Cancer, Cooked meat, Metabolism, Biomarkers

\section{Introduction}

Professor Takashi Sugimura serendipitously discovered mutagens/carcinogens produced in cooked meat and fish over 40 years ago. His wife was broiling fish in the kitchen, and the smoke caught Professor Sugimura's attention. He reasoned that if cigarette smoke contains many mutagens, why not smoke produced by broiling fish $[1,2]$ ? His observation stimulated research worldwide

\footnotetext{
* Correspondence: Rturesky@umn.edu

${ }^{1}$ Masonic Cancer Center and Department of Medicinal Chemistry, Cancer and Cardiovascular Research Building, University of Minnesota, 2231 6th Street, Minneapolis, MN 55455, USA

${ }^{2}$ Department of Medicinal Chemistry, College of Pharmacy, University of Minnesota, Minneapolis, MN 55455, USA

Full list of author information is available at the end of the article
}

on cooked food mutagens which led to the identification of more than 20 genotoxic HAAs formed in cooked meat, poultry, and fish [3-8]. Subsequent studies showed that rodents fed HAAs as part of the diet developed cancers in many organs, including the liver, colon, pancreas, breast, and prostate [9-13]. These are common cancer sites in Western countries and are increasing in Japan and other Asian countries adapting Western dietary habits [2]. The subject of dietary mutagens has been an active area of research since Professor Sugimura discovered HAAs and highlighted in his salient review articles over the past five decades [1, 2, 11, 14-17].

C C The Author(s). 2021 Open Access This article is licensed under a Creative Commons Attribution 4.0 International License, which permits use, sharing, adaptation, distribution and reproduction in any medium or format, as long as you give appropriate credit to the original author(s) and the source, provide a link to the Creative Commons licence, and indicate if changes were made. The images or other third party material in this article are included in the article's Creative Commons licence, unless indicated otherwise in a credit line to the material. If material is not included in the article's Creative Commons licence and your intended use is not permitted by statutory regulation or exceeds the permitted use, you will need to obtain permission directly from the copyright holder. To view a copy of this licence, visit http://creativecommons.org/licenses/by/4.0/ The Creative Commons Public Domain Dedication waiver (http://creativecommons.org/publicdomain/zero/1.0/) applies to the data made available in this article, unless otherwise stated in a credit line to the data. 


\section{HAA discovery}

Professor Sugimura and his colleague Dr. Minako Nago showed that smoke generated by broiled fish was strongly mutagenic in the Ames Salmonella test [18]. Many HAAs are potent bacterial mutagens in the frameshift tester strain Salmonella typhimurium TA98 [1]. The Ames test proved to be an invaluable guide to isolate these novel mutagens from complex cooked food matrices [19]. During the following four decades, many HAAs were identified in cooked foods. The structures of prevalent HAAs are shown in Fig. 1.

\section{HAA formation}

Several HAAs arise during high-temperature pyrolysis of tryptophan, glutamic acid, or proteins to form 3amino-1,4-dimethyl-5 $H$-pyrido[4,3-b]indole (Trp-P-1), 3-amino-1-methyl-5H-pyrido[4,3- $b$ ]indole (Trp-P-2), 2amino-6-methyldiprido[1,2- $a: 3^{\prime}, 2^{\prime}$ - $\left.d\right]$ imidazole (Glu-P-1), 2aminodiprido[1,2-a:3',2'-d] imidazole (Glu-P-2), 2-amino$9 H$-pyrido[2,3-b]indole $(\mathrm{A} \alpha \mathrm{C})$, and 2-amino-3-methyl-9Hpyrido[2,3-b]indole $(\mathrm{MeA} \alpha \mathrm{C})$ [1, 20, 21]. Several pyrolysis HAAs were identified in charred meats and combusted tobacco [3, 22-26]. After these early studies, Kasai and coworkers showed that the highly mutagenic chemicals formed in broiled fish and beef were distinct from the amino acid pyrolysates, which led to the discovery of the second class of HAAs, the aminoimidazoarenes (AIAs), including 2-amino-3-methylimidazo[4,5-f] quinoline (IQ), 2amino-3,4-dimethylimidazo[4,5-f quinoline (MeIQ), and 2amino-3,8-dimethylimidazo[4,5-f quinoxaline (MeIQx) [27-30]. The Felton laboratory subsequently identified 2- amino-1-methyl-6-phenylimidazo[4,5-b]pyridine (PhIP) in fried ground beef [31]. The amounts of HAAs increase in meats as a function of time and cooking temperature; $\mathrm{PhIP}$ and $\mathrm{A} \alpha \mathrm{C}$ levels, in particular, can form at levels up to 50 parts-per-billion (ppb) or higher in well-done cooked meat and poultry compared to other HAAs [3, 4, 25, 32-36]. Pan-fried or grilled scrapings often used for gravies also contain elevated concentrations of HAAs [37, 38]. Other structurally related genotoxic HAAs were subsequently identified in cooked meats, fish, and poultry, including linear tricyclic isomers of the angular tricyclic ring 2amino-3-methylimidazo[4,5-f]quinoxaline (IQx) and its methylated homologs $[25,39,40]$.

Since HAAs typically form at the low ppb concentrations in cooked meats, early studies employed model systems to elucidate critical precursors involved in HAA formation. Jägerstad conducted studies with model systems containing amino acids and sugars and showed that creatine or creatinine was the precursor of the imidazo moieties for AIA-type compounds [41]. Later, Murkovic identified phenylacetaldehyde as a critical precursor in PhIP formation [42]. Reactive carbonyl compounds, including acrolein, glucose, and Strecker degradation products are involved in IQ and IQx, and MeIQx formation [41-43].

Recently, Totsuka, Wakabayashi, and co-workers identified several novel HAAs, which are formed from $\beta$ carbolines and aniline or $o$-toluidine in biological systems under physiological conditions to produce 9-(4'-aminophenyl)-9H-pyrido[3,4-b]indole (aminophenylnorharman, APNH) and 9-(4'-amino-3' -methylphenyl)-9H-pyrido [3,4b] indole (aminomethylphenylnorharman, AMPNH) [44].
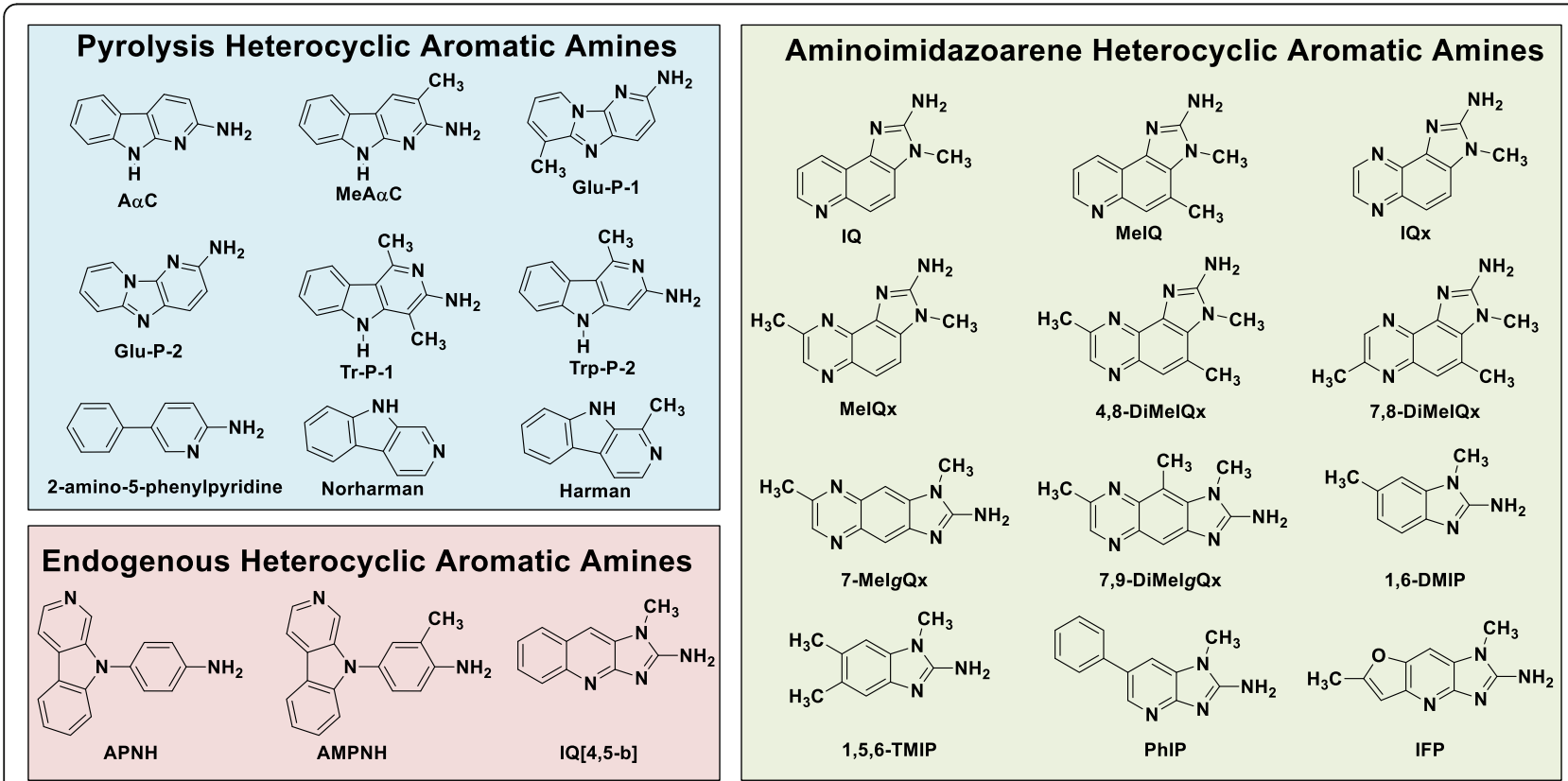

Fig. 1 Chemical structures of prevalent HAAs 
APNH and AMPNH form by the reaction of norharman with the N-hydroxylated metabolites of aniline or $o$-toluidine, resulting in potent genotoxicants [44]. APNH induces hepatic and colon tumors in Fisher-F344 (F344) rats, with high incidence. APNH is detected in the urine of smokers and nonsmokers, indicating its formation occurs endogenously [45]. A linear tricyclic ring isomer of IQ, 2-amino-1methylimidazo $[4,5-b]$ quinoline (IQ[4,5- $b]$ ), is also formed endogenously in human urine by condensation of creatinine with 2-aminobenzaldehyde [46]. Its genotoxic potential has not been assessed.

\section{Mutagenesis and carcinogenesis HAA mutagenicity in bacteria}

HAAs are potent bacterial mutagens in the Ames frameshift- Salmonella typhimurium strains TA97, TA98, and TA1538 but display weaker activity in point mutation TA100 and TA1535 strains (Table 1) [2, 5, 47]. AIAs, including IQ, MelQ, and MelQx, are more potent mutagens than the amino acid pyrolysate HAAs [2, 5, 47]. AIAs induce a CG-dinucleotide deletion in a run of -CGCGCGCG- situated about ten bases upstream from the original hisD3052 - C- deletion in the frameshift Salmonella strain TA1538 [48]. The strain selectivity and the types of mutations induced by HAAs are consistent with HAA adducts formed with guanine [49]. Some HAAs are more potent mutagens in the Ames assay compared to other carcinogens, including aflatoxin $B_{1}$ $\left(\mathrm{AFB}_{1}\right)$ and benzo[a]pyrene $(\mathrm{B}[a] \mathrm{P})$. However, these striking differences in mutagenic potency are not observed in mammalian cells. The potent mutagenicity of HAAs in the Salmonella typhimurium-based assays

Table 1 HAA mutagenicity in S. typhimurium tester strains TA98 and TA100,

\begin{tabular}{lll}
\hline HAA & Revertants/ug & \\
\cline { 2 - 3 } & TA98 & TA100 \\
\hline IQ & 433,000 & 7000 \\
MelQ & 661,000 & 30,000 \\
IQx & 75,400 & 1500 \\
MelQx & 145,000 & 14,000 \\
4,8-DiMelQx & 183,000 & 8000 \\
7,8-DiMelQx & 163,000 & 9900 \\
PhIP & 1800 & 120 \\
Trp-P-1 & 39,000 & 1700 \\
Trp-P-2 & 104,000 & 1800 \\
Glu-P-1 & 49,000 & 3200 \\
Glu-P-2 & 1900 & 1200 \\
AaC & 300 & 20 \\
MeAaC & 200 & 120 \\
\hline
\end{tabular}

${ }^{a}$ with rat liver $\mathrm{S} 9$ for metabolic activation

${ }^{\mathrm{b}}$ reproduced with permission from [2] may be attributed to the high expression of esterifying acetyltransferase enzymes, which produce the reactive $\mathrm{N}$-acetoxy-HAA intermediates that form DNA adducts [49]. For example, IQ and MeIQx are much weaker mutagens in Salmonella typhimurium TA98/1,8DNP6, an $O$-acetyltransferase deficient strain than in YG1024, an $O$-acetyltransferase competent strain [50, 51].

Mutagenicity of HAAs has been studied in Escherichia coli using lacZ, lacZ $\alpha$, and lacI genes as endpoints. HAA-induced mutations mainly occurred at GC base pairs [52-54]. For example, the MeIQx mutational spectrum in lacZ $\alpha$ gene is dominated by frameshift mutations (54\%) followed by base substitution mutations (41\%), while complex mutations represented $5 \%$ of the total [54]. Over $90 \%$ of the MeIQx-induced mutations occurred at GC base pairs and clustered in two hotspots with runs of three or five GC base pairs. The frameshift mutations were found at position 2576, while base substitutions were mainly observed at position 2532 [54].

\section{HAA mutagenicity in mammalian cells}

HAA mutagenicity has been studied in Chinese wildtype and repair-deficient hamster ovary $(\mathrm{CHO})$ cells, employing hprt and aprt loci, [55] and in Chinese hamster lung (CHL) cells at diphtheria-toxin resistance locus [56]. Trp-P-2 showed the highest mutagenic activity in CHL cells, followed by Trp-P-1, MeIQ, IQ, A $\alpha$ C, MeIQx, Glu-P-1, and Glu-P-2. Except for Trp-P-1, all the tested compounds required exogenous metabolic activation [56]. In CHO cells, IQ, MeIQ, and MeIQx induced weak cytotoxic effects, hprt mutations, and sister chromatid exchange induction. These effects did not occur in a dose-dependent fashion and only occurred at concentrations that exceeded $10 \mu \mathrm{g} / \mathrm{mL}$ for IQ and $100-$ $800 \mu \mathrm{g} / \mathrm{ml}$ for MeIQ and MeIQx [55, 57]. IQ, MeIQ, and MeIQx-induced cytotoxicity were not altered in the repair-deficient $\mathrm{CHO}$ cell line and are likely due to mechanisms other than DNA damage [55, 57]. PhIP, a much weaker bacterial mutagen than IQ, MeIQ, or MeIQx, induced potent cytotoxic effects, hprt mutations, sister chromatid exchange, and chromosomal aberrations. These effects were more pronounced in the repair-deficient than the wild-type cell line [55]. PhIP induces GC>TA transversions at the hprt locus in human lymphoblastoid cells [58], GC>TA transversions at the dhfr gene and $\mathrm{AT}>\mathrm{TA}, \mathrm{CG}>\mathrm{AT}$, and $\mathrm{GC}>\mathrm{TA}$ transversions at aprt in $\mathrm{CHO}$ cells $[59,60]$, and GC>TA transversions at the hprt locus in Chinese hamster V79 cells [61]. Frameshift mutations at guanine were also reported and influenced by the base sequence context. In XEMh1A2-MZ, a Chinese hamster cell line genetically engineered to express human cytochrome P450 1A2 (CYP1A2), PhIP induced - 1G frameshift mutation; 5'GGGA-3' to 5'-GGA-3' [61]. This mutation occurred 
in the tumor suppressor gene adenomatous polyposis coli (APC) in 50\% of PhIP-induced colon tumors in rats [62]. Collectively, these mutations are consistent with HAA-guanine adducts being the primary site of HAADNA adduct formation [49, 63, 64].

HONH-PhIP mutagenesis was investigated by wholegenome sequencing (WGS) in human TP53 knock-in (Hupki) mouse embryo fibroblasts, and mutagenicity in TP53 and the lacZ reporter gene [65]. All HONH-PhIP induced TP53 mutations occurred at G:C base pairs with CG $>$ TA transversions accounting for most of the mutations; these TP53 mutations are found in human breast and colorectal tumors cancer types associated with PhIP exposure. LacZ mutant frequency increased 25-fold at $5 \mu \mathrm{M}$ HONH-PhIP, forming the mutation-prone DNA adduct $N$-(2'-deoxyguanosin-8-yl)-PhIP (dG-C8-PhIP) at 350 adducts per $10^{8}$ nucleotides. A WGS mutational signature defined by $\mathrm{CG}>\mathrm{TA}$ transversion was present in HONH-PhIP-treated immortalized clones, which showed similarity to COSMIC SBS4, SBS18, and SBS29 mutational signatures found in human tumors [65].

\section{HAA mutations in rodents}

HAA-induced mutations of oncogenes and tumorsuppressor genes were examined in rodent tumors following long-term feeding studies [66-68]. These studies generally employed the maximum tolerable HAA doses. HAAs induce mutations in several oncogenes and tumor suppressor genes, including Apc, Ha-ras, Ki-ras, p53, and $\beta$-Catenin (Table 2). The APC mutation is responsible for familial adenomatous polyposis and also a major rate-limiting and early event in colorectal cancer development [69]. Over half of the PhIP-induced colon tumors in F344 rats harbored a GC base pair deletion in 5'-GTGGGA-3' at codon 635 of the APC gene. This mutation was detected after 1 week of feeding and increased in a dose- and time-dependent manner [62, 70]. This same deletion at 5'-GGGA-3' occurred in the lacI gene of the colon mucosa of the transgenic Big Blue ${ }^{\circ}$ mice and Big Blue rats, the lacI gene of mammary glands of female Big Blue rats, and in lacI gene of the prostate of Big Blue male rats treated with PhIP [71-74]. This GC base pair deletion at the 5'GGGA-3' sequence may be a signature mutation of PhIP.

IQ-induced mutations in the $A P C$ gene occurred in rat colon tumors but only in 2 out of 13 tumors analyzed [62]. IQ and PhIP induced mutations in $\beta$-Catenin gene with high frequency in rat colon. Interestingly, the tumors with $\beta$-Catenin mutations harbored a wild-type $A P C$, while tumors with mutated APC harbored a wildtype $\beta$-Catenin. These data demonstrate the need for only a single mutation in the $\beta$-Catenin/APC pathway for PhIP-colon carcinogenesis [75]. IQ- and PhIPinduced colon tumors did not harbor mutations in the ras genes family [2]. In contrast, Ha-ras mutations occurred in PhIP-induced mammary gland tumors of female F344 and Sprague-Dawley rats [76]. Ha-ras mutations were also detected in IQ-induced liver tumors in $\mathrm{CDF}_{1}$ mice, MeIQ-induced forestomach tumor in $\mathrm{CDF}_{1}$ mice, and IQ-, MeIQ, and MeIQx-induced Zymbal's gland of F344 rats [67, 77-79]. IQ-induced Ki-ras mutations in the lung and Zymbal's gland tumors of $\mathrm{CDF}_{1}$ mice and F344 rats, respectively [67, 80]. p53 mutations infrequently occurred in PhIP-induced mammary gland tumors in F334 rats, MeIQx-induced liver tumors in F334 rats, IQ-induced Zymbal's gland tumors in F334 rats, and MeIQ-induced forestomach tumors in $\mathrm{CDF}_{1}$ mice [2]. IQ induced $p 53$ mutations in 4 of 20 nonhuman primates hepatic tumors: 3 out of 4 mutations were identified as GC>TA transversions, while the fourth

Table 2 HAA mutagenicity in rodents ${ }^{a}$

\begin{tabular}{|c|c|c|c|c|c|c|c|c|c|c|c|c|}
\hline \multirow[t]{2}{*}{ HAA } & \multirow[t]{2}{*}{ Animal } & \multirow[t]{2}{*}{ Strain } & \multirow[t]{2}{*}{ Target organ } & \multicolumn{9}{|c|}{ Mutations } \\
\hline & & & & H-ras & Ki-ras & N-ras & p53 & APC & $\beta$-Cat & MM & Lacl & LacZ \\
\hline \multirow[t]{5}{*}{ PhIP } & Rat & F344 & Colon & $0 / 9$ & $0 / 9$ & $0 / 9$ & $0 / 9$ & $4 / 8$ & $4 / 7$ & $7 / 8$ & & \\
\hline & & Big Blue & Colon mucosa & & & & & & & & $227 / 227$ & \\
\hline & & & Mammary gland & & & & & & & & $149 / 149$ & \\
\hline & Mouse & CDF1 & Lymphoid tissue & & & & & & & & & \\
\hline & & Big Blue & Colon mucosa & & & & & & & & $115 / 115$ & $40 / 40$ \\
\hline MelOx & Rat & F344 & Zymbal gland & $2 / 6$ & & & & & & & & \\
\hline MelQ & Rat & F344 & Zymbal gland & $11 / 14$ & & & & & & & & \\
\hline \multirow[t]{4}{*}{ IQ } & Rat & F344 & Colon & $0 / 11$ & $0 / 11$ & $0 / 11$ & $0 / 11$ & $2 / 13$ & $5 / 5$ & & & \\
\hline & & & Zymbal gland & $4 / 7,5 / 9$ & $3 / 9$ & & $4 / 15$ & & & & & \\
\hline & Mouse & CDF1 & Liver & $7 / 34$ & & & & & & & & \\
\hline & & & lung & & $49 / 54$ & & & & & & & \\
\hline Glu-P-1 & Rat & F344 & Colon & $0 / 7$ & $1 / 7$ & $0 / 6$ & $0 / 7$ & & & & & \\
\hline
\end{tabular}

\footnotetext{
a reproduced with permission $[2,68]$
} 
mutation was a GC>AT transition [81] (Table 2). These data suggest that dG-HAA adducts are responsible for the induced mutations [49].

\section{HAA carcinogenicity}

HAAs are multi-site carcinogens with targeted organs including liver, lung, hematopoietic system, forestomach, and blood vessels in mice, and colon, small intestine, prostate, mammary gland, hematopoietic system, liver, Zymbal's gland, skin, clitoral gland, oral cavity, and urinary bladder in rats (Table 3) $[68,82,83]$. Some epidemiological studies report that frequent consumption of well-done cooked meat, the primary source of HAA exposure, is linked to breast, colon, and prostate cancer risk [84-89]. It is noteworthy that PhIP is the only HAA and dietary mutagen reported to induce prostate tumors in rodents $[13,90]$.

PhIP, MeIQx, and IQ cancer bioassays were also conducted in non-human primates [91]. IQ is a potent hepatocellular carcinogen at doses of 10 or $20 \mathrm{mg} / \mathrm{kg}$ in cynomolgus monkeys. The latent period was 60 months with the lowest dose and 43 months with the highest dose. Metastasis of the hepatocellular carcinomas occurred in the lungs of several animals. MeIQx was administered to cynomolgus monkeys at the same doses as for IQ for 84 months but did not induce tumors, only sporadic and non-treatment-related aberrant crypt foci in the colon, glutathione S-transferase pi-positive foci in the liver, and hyperplasia of the lymphatic tissue in the lung and gastrointestinal tract were observed. PhIP also did not induce cancer in cynomolgus monkeys employing the same doses and regimens as for IQ and MeIQx. The wide discrepancy in carcinogenicity between these structurally related HAAs may be attributed to differences in their metabolic activation. Cynomolgus monkeys lack hepatic CYP1A2, which bioactivates all three HAAs [92, 93]. However, IQ is also bioactivated by CYP3A4, CYP2C9, and CYP2C10 isoforms, which may contribute to IQ's carcinogenicity in the cynomolgus monkey [92]. The marmoset monkey, which constitutively expresses CYP1A2, may be a superior model

Table 3 HAA carcinogenicity in animals ${ }^{a}$

\begin{tabular}{|c|c|c|c|c|c|}
\hline HAA & Animal & Strain & Dose $(\mathrm{mg} / \mathrm{kg})$ & $\begin{array}{l}\text { Exposure peroid } \\
\text { (weeks) }\end{array}$ & Target organ \\
\hline \multirow[t]{5}{*}{ PhIP } & Rat & F344 & 400 & 52 & Colon, Mammary gland, Prostate, Lymphoid tissue \\
\hline & & Big Blue & 400 & 60 & Colon mucosa, Mammary gland \\
\hline & Mouse & CDF1 & 400 & 82 & Lymphoid tissue \\
\hline & & $\mathrm{C} 57 \mathrm{BL} / 6 \mathrm{~N}$ & 300 & $70-95$ & Small intestine, Lymphoid tissue \\
\hline & & Big Blue & 300 & & Colon mucosa \\
\hline \multirow[t]{2}{*}{ MelOx } & Rat & F344 & 400 & 61 & Liver, Zymbal gland, Clitoral gland, Skin \\
\hline & Mouse & CDF1 & 600 & 84 & Liver, lung, Hematopoietic system \\
\hline \multirow[t]{4}{*}{ MelQ } & Rat & F344 & 300 & 40 & Colon, Zymbal gland, Skin, Oral cavity, Mammary gland \\
\hline & Mouse & CDF1 & 400 & 91 & Liver, Forestomach \\
\hline & & $\mathrm{C} 57 \mathrm{BL} / 6$ & 300 & & Liver, Colon \\
\hline & & Big Blue & 300 & 60 & Colon mucosa \\
\hline \multirow[t]{3}{*}{ IQ } & Rat & F344 & 300 & $55-72$ & Liver, Small intestine, Colon, Zymbal gland, Clitoral gland, Skin \\
\hline & Mouse & CDF1 & 300 & 96 & Liver, Forestomach, lung \\
\hline & Monkey & cynomolgus & $10-20$ & $172-240$ & Liver \\
\hline \multirow[t]{2}{*}{ MeAaC } & Rat & F344 & 100 & 100 & Liver \\
\hline & Mouse & CDF1 & 800 & 84 & Liver, Blood vessels \\
\hline $\mathrm{AaC}$ & Mouse & CDF1 & 800 & 98 & Liver, Blood vessels \\
\hline \multirow[t]{2}{*}{ Glu-P-1 } & Rat & F344 & 500 & 64 & Liver, Small intestine, Colon, Zymbal gland, Clitoral gland \\
\hline & Mouse & CDF1 & 500 & 57 & Liver, Blood vessels \\
\hline \multirow[t]{2}{*}{ Glu-P-2 } & Rat & F344 & 500 & 104 & Liver, Small intestine, Colon, Zymbal gland, Clitoral gland \\
\hline & Mouse & CDF1 & 500 & 84 & Liver, Blood vessels \\
\hline \multirow[t]{2}{*}{ Trp-P-1 } & Rat & F344 & 150 & 52 & Liver \\
\hline & Mouse & CDF1 & 200 & 89 & Liver \\
\hline \multirow[t]{2}{*}{ Trp-P-2 } & Rat & F3444 & 100 & 112 & Liver, Bladder \\
\hline & Mouse & CDF1 & 200 & 89 & Liver \\
\hline
\end{tabular}

${ }^{\mathrm{a}}$ reproduced with permission from [2] 
to the cynomolgus monkey for carcinogenicity studies involving HAAs [93].

\section{PhIP prostate carcinogenicity and mechanistic studies in rodents}

PhIP induces prostate tumors in the F344 rat [13] and CYP1A-humanized (h-CYP1A) C57BL/6 mice but not in wild-type mice [90], signifying a critical role for human CYP1A2 in PhIP metabolism and tumorigenesis. PhIP forms DNA adducts at high levels in the prostate of Wistar and F344 rats [13, 94, 95] and induces high levels of lacI gene mutations in the prostate of the Big Blue ${ }^{\circ}$ transgenic rat $[74,96]$. The dorsolateral prostate lobe of the rodent prostate is homologous to the human peripheral prostate zone, the most common site of prostate cancer (PC) development in humans [97]. PhIP induces inflammation, glandular atrophy, high-grade prostatic intraepithelial neoplasia, and oxidative stress in the prostate of hCYP1A mice and the F344 rat [90, 96, 98, 99]; these are pathology features in common with human PC [97]. PhIP treatment increased the expression of the androgen receptor (AR), a key regulator for prostate cell proliferation, increased expression levels of Ki-67, a marker of cell proliferation, and increased expression levels of COX-2, a cyclooxygenase that catalyzes the formation of pro-inflammatory prostaglandin in the prostate of rats and h-CYP1A mice [90, 96, 99]. PhIP also decreased the levels of Nuclear Factor (erythroid-derived 2)-like 2 (Nrf2), a transcription factor of several cytoprotective proteins, E-Cadherin, an epithelial cell adhesion protein, and also decreased levels of p63, phosphatase, and tensin homolog (PTEN), key players key players in cell proliferation and apoptosis [90, 96, 99]. These features are hallmarks for human PC and serve as diagnostic criteria for this malignancy [100-103]. The mutagenic, carcinogenic, and molecular events induced by PhIP in rodent prostate strengthen the unconfirmed paradigm of PhIP playing a role in cooked red-meat related PC etiology [87]. However, the doses of PhIP used in animal studies were a million-fold or higher than the daily intake of PhIP in the human diet. Thus, studies at dietary PhIP exposure levels are warranted to understand the biological effects and potential role of PhIP in human PC.

\section{Metabolism: bioactivation and detoxication of HAAs Phase I and phase II enzymes}

The metabolism of several prevalent HAAs have been characterized in rodents, non-human primates, and humans (Fig. 2). Both phase I and II enzymes contribute to HAA metabolism.

\section{Cytochrome P450 oxidation of HAAs}

The bioactivation of HAAs occurs by $\mathrm{N}$-oxidation of the exocyclic amine groups to produce the HONH-HAAs. The liver displays the highest metabolic activity in rodents, particularly after enzyme induction with 3methylcholanthrene or polychlorinated biphenyl $[64,104]$.

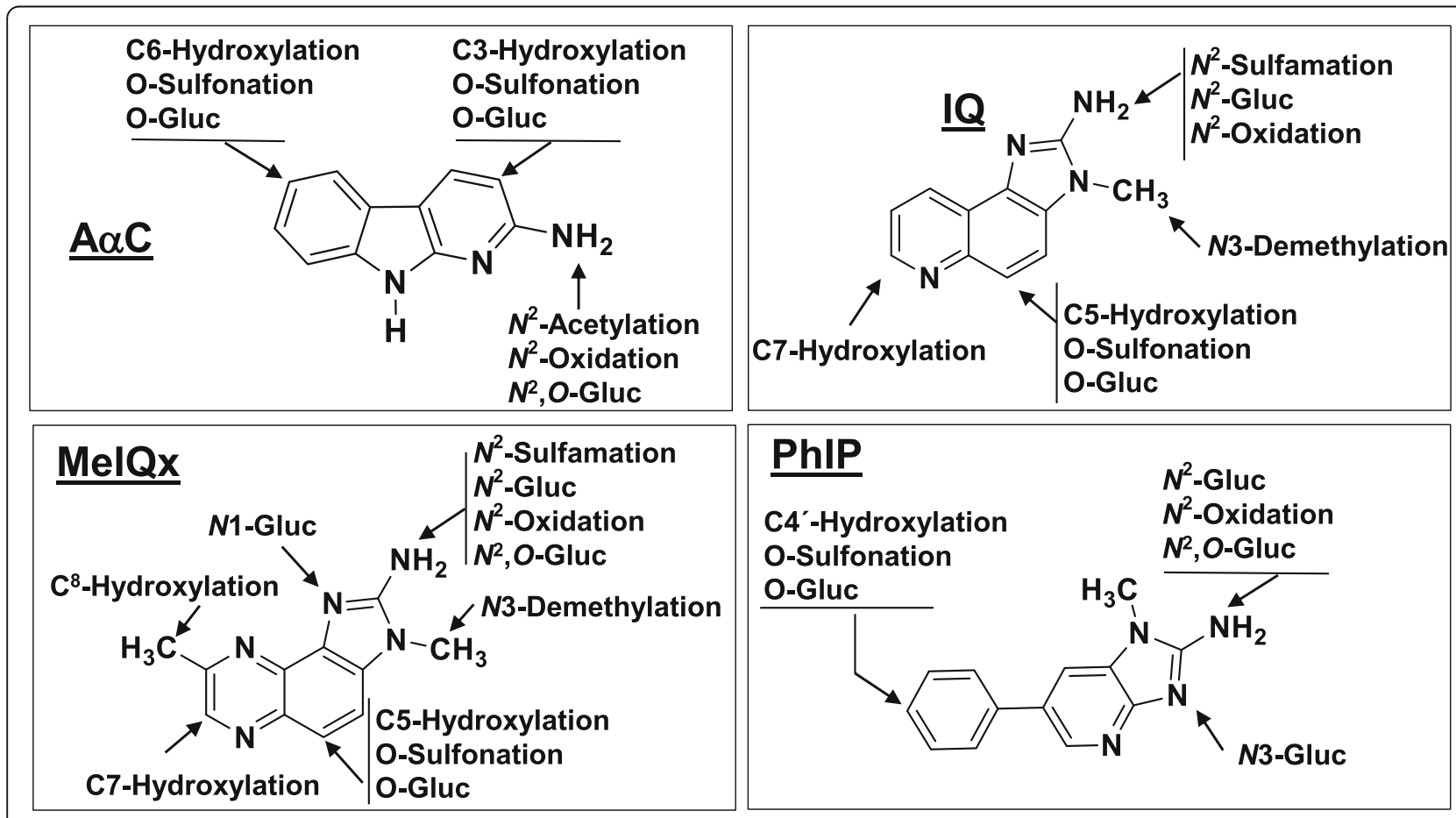

Fig. 2 Major pathways AaC, IQ, MelQx, and PhIP metabolism in experimental laboratory animals and humans 
The HONH-HAAs are genotoxic metabolites that covalently bind to DNA to form mutation-prone DNA adducts $[63,64]$. Hepatic cytochrome (CYP) CYP1A2 and extrahepatic CYP1A1 and CYP1B1 are principal CYPs that catalyze HAA N-oxidation in humans [64, 93, 105-108]. A pharmacokinetic study estimated that CYP1A2 accounts for $91 \%$ of the metabolism of MeIQx and 70\% of the PhIP metabolism in humans [105]. The major CYP1A2 pathway of PhIP metabolism occurs through N-oxidation to form the genotoxic $N$-hydroxy-2-amino-1-methyl-6-phenylimidazo[4,5-b]pyridine (HONH-PhIP) metabolite, whereas the major CYP1A2 pathway of MeIQx metabolism is through oxidation of the 8-methyl group to form the detoxicated product 2-amino-3-methylimidazo[4,5-f]quinoxaline-8-carboxylic acid (IQx-8-COOH) [49, 109].

There are critical interspecies differences in HAA metabolism by CYPs among rodents, nonhuman primates, and humans that are mainly attributed to different levels of CYP expression, differences in catalytic activities, and regioselectivities of CYPs towards HAAs (Figs. 2 and 3) [93, 107, 110-113]. CYP1A2 expression in the human liver ranges from 5 to 300 pmol per $\mathrm{mg}$ of microsomal protein, whereas CYP1A2 expression in non-induced rat liver typically ranges between 10 and $35 \mathrm{pmol} / \mathrm{mg}$ microsomal protein in various rat strains and undetected in the cynomolgus monkeys $(<1 \mathrm{pmol} /$ $\mathrm{mg}$ microsomal protein) used in carcinogenesis bioassays (Fig. 3) [2, 93, 107, 114-116]. CYP1A2 expression in human liver microsomes is highly correlated to MeIQx and PhIP N-oxidation rates (Fig. 3) [107]. Compared to human liver microsomes, rat and cynomolgus monkey liver microsomes poorly bioactivate IQ, MeIQx, and PhIP to their genotoxic $\mathrm{HONH}-\mathrm{HAA}$ intermediates because of low CYP1A2 expression but efficiently catalyze HAA ring oxidation, a detoxication pathway, whereas CYPs in human liver microsomes poorly carry out this reaction (Fig. 2) [92, 93, 107, 110-113, 117]. Human CYP1A2 catalyzes IQx-8-COOH formation, the predominant detoxicated metabolite of MeIQx formed in human hepatocytes $[109,118]$, and IQx-8-COOH is the major urinary metabolite of MeIQx in the urine of meat-eaters [119-122]. Rat CYPs do not catalyze IQx-8-COOH formation (Fig. 2). Recombinant human CYP1A2 shows catalytic efficiencies of MeIQx and PhIP N-oxidation 10-19-fold higher than rat CYP1A2 [107, 117]. In contrast, both human and rat CYP1A2 orthologs display similar catalytic efficiency in the $\mathrm{O}$-demethylation of 7methoxyresorufin (Fig. 4). These interspecies distinctions in enzyme expression and activities impact the biological effects of HAAs and must be considered when assessing the human health risk of HAAs based on experimental animal toxicity data $[107,118,123]$.

\section{Phase II metabolism of HAAs}

Phase II enzymes have a dual role in HAA metabolism, contributing to detoxication and bioactivation. Some HAAs undergo detoxication through direct conjugation of their exocyclic amine groups by phase II enzymes, including $\mathrm{N}$-acetyltransferases (NATs), sulfotransferases (SULTs), and uridine 5'-diphosphoglucuronosyltransferases (UGTs) [49]. NAT1 and NAT2 are two distinct $\mathrm{N}$-acetyltransferase isoenzymes. NAT2 is expressed primarily in the liver, whereas NAT1 is prominently expressed in extrahepatic tissues [124]. Many structurally related carcinogenic aromatic amines undergo by NATs $[125,126]$. Glu-P-I, Glu-P-2, and A $\alpha \mathrm{C}$ undergo extensive N-acetylation [127-130]; however, AIAs are poor substrates for NATs [49]. Human sulfotransferases (SULTs) belong to a superfamily of genes that are divided into two subfamilies: the phenol SULTs (SULT1) and the hydroxysteroid SULTs (SULT2). SULT1A1, $1 \mathrm{~A} 3$, and $1 \mathrm{~B} 1$ are expressed in all parts of the gastrointestinal tract, often exceeding the protein levels expressed in the liver [131-134]. In addition to sulfating
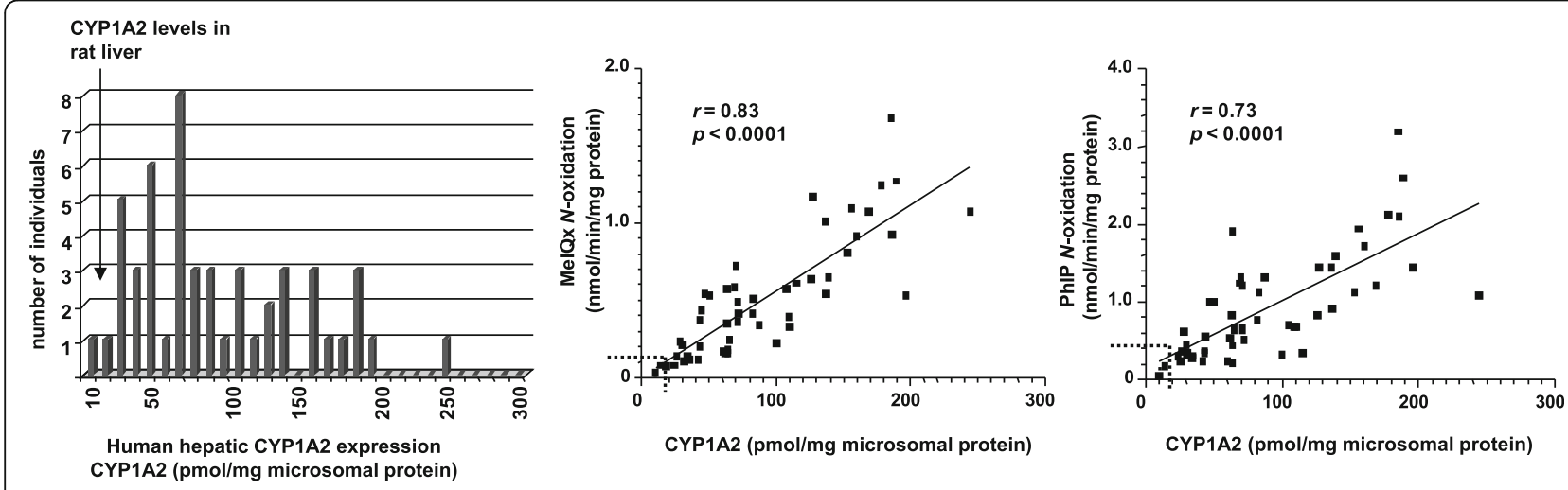

Fig. 3 Levels of CYP1A2 expression in rat and human liver microsomes correlates with CYP1A2 expression, MelQx, and PhIP N-oxidation rates. The checkered lines depicted in the regression curves show the upper levels of CYP1A2 expression and MelQx and PhIP N-oxidation rates in rat liver microsomes. Adapted with permission from [107] 

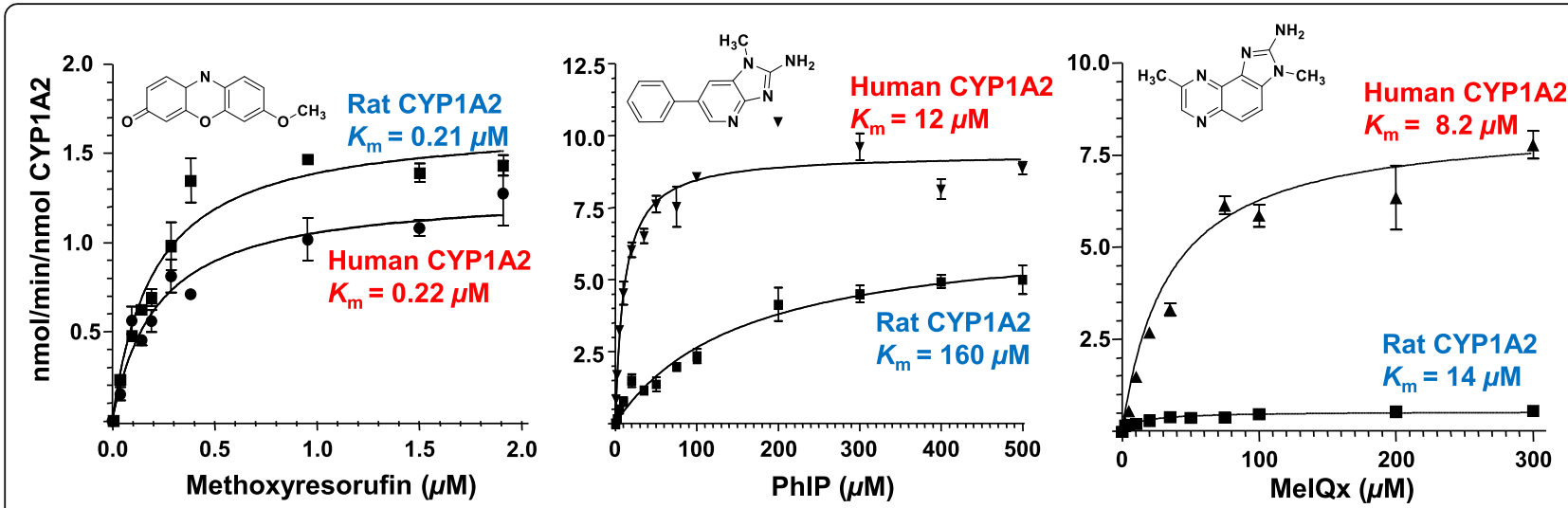

Fig. 4 Kinetic parameters of MelQx, PhIP N-oxidation, and methoxyresoruin oxidative demethylation by rat and recombinant human CYP1A2

phenolic xenobiotics, steroids, and estrogens, SULTs contribute to the detoxication and bioactivation of HAAs. IQ and MeIQx form sulfamic acid derivatives as prominent detoxication metabolites in rats and catalyzed by SULT1A1 [135-137]. The MeIQx sulfamate $N^{2}-(3,8-$ dimethylimidazo[4,5-f]quinoxalin-2-yl-sulfamic acid $\left(\mathrm{MeIQx}-\mathrm{N}^{2}-\mathrm{SO}_{3} \mathrm{H}\right)$ is detected in human urine [119]. Other HAAs do not undergo sulfamation in rodents or humans; however, sulfate conjugates of HAA ringhydroxylated metabolites occur, particularly in rodents and nonhuman primates $[49,92,138]$. The UGTs are subdivided in the $1 \mathrm{~A}, 2 \mathrm{~A}$, and $2 \mathrm{~B}$ subfamilies and expressed in liver and extrahepatic tissues, and play a major role in drug and steroid metabolism [139, 140]. UGTs catalyze $N^{2}$-glucuronide (Gluc) formation of IQ, PhIP, A $\alpha$ C, N1- and $N^{2}$-Gluc conjugates of MeIQx, and $N^{2}$ - and N3-Gluc conjugates of PhIP $[49,138,141,142]$. The UGT1A enzyme family is principally involved in the N-Gluc of PhIP [143] and most likely MeIQx in humans [109]. The Gluc conjugates of PhIP and MeIQx are excreted in meat-eaters' urine [119, 144].

NATs, SULTs, and kinases catalyze the bioactivation of HONH-HAAs through the formation of highly reactive esters to produce the penultimate species that covalently bind DNA [63, 64, 111, 145]. Most HONH-HAAs undergo bioactivation by human NAT2 [133, 146-149], although both isoforms bioactivate HONH-A $\alpha \mathrm{C}$ [128]. The $N$-acetoxy intermediates of $N$-hydroxyamino-3,8dimethylimidazo[4,5-f $]$ quinoxaline (HONH-MeIQx), $N$ hydroxy-2-amino-3-methylimidazo[4,5-f $]$ quinoline

(HONH-IQ), and $N$-hydroxyamino- $9 H$-pyrido[2,3-b]indole $(\mathrm{HONH}-\mathrm{A} \alpha \mathrm{C})$ are short-lived and cannot be isolated [150, 151]. However, $N$-acetoxy-PhIP is sufficiently stable for HPLC isolation and characterization by mass spectrometry, allowing distinction between $\mathrm{N}$-acetoxyPhIP and its hydroxamic acid isomer [152, 153]. Human SULT1A1 and SULT1A2 catalyze the binding of the $N$ - hydroxy metabolites of PhIP, $\mathrm{A} \alpha \mathrm{C}$, and $\mathrm{MeA} \alpha \mathrm{C}$ to DNA; the $\mathrm{N}$-hydroxy metabolites of MeIQx and IQ are poor substrates for both SULT isoforms [154-157].

Gluc conjugation of HONH-HAAs occurs at the exocyclic amine group to form proposed detoxication metabolites [158]. Human liver microsomes catalyze Gluc formation of $N$-hydroxy-HAAs of IQ, MeIQx, PhIP, and $\mathrm{A} \alpha \mathrm{C}[142,158-160]$. Many of these metabolites are excreted in urine of meat-eaters $[49,120,122,144,161]$. UGTs 1A1, 1A4, and 1A9 catalyze Gluc of HONH-PhIP $[158,159,162-164] . N^{2}$-( $\beta$-D-glucosiduronyl)-2-hydroxyamino-1-methyl-6-phenylimidazo[4,5-b]pyridine (PhIP$\mathrm{HON}^{2}$-Gluc) is the major HONH-PHIP Gluc conjugate formed in rat hepatocytes and with human liver microsomes [158, 162]. A second isomeric Gluc conjugate of HONH-PhIP forms, but the limited quantity of material precluded its characterization by NMR [158]. The site of Gluc conjugation was proposed to occur at the N3 imidazole atom of the oxime tautomer of HONH-PhIP (HONPhIP-N3-Gluc) (Fig. 5), based on comparison of UV spectral and biochemical properties to those of the $N^{2}$ - and N3-Gluc conjugates of PhIP [141, 158]. Our laboratory further characterized both HONH-PhIP Gluc metabolites by high-resolution accurate mass spectrometry [160]. The product ion spectra acquired in the negative ion mode clearly showed that the minor Gluc metabolite was conjugated to the oxygen atom of HONH-PhIP to produce $O$ ( $\beta$-D-glucosiduronyl)-2-hydroxyamino-PhIP (PhIP-HN ${ }^{2}$ $O$-Gluc) (Fig. 6) and not conjugated to the $N 3$ imidazole atom of the oxime as was originally proposed (Fig. 5) [158]. Recombinant UGT1A1 and UGT1A4 preferentially catalyze PhIP-HO- $N^{2}$-Gluc, while UGT1A9 produced greater amounts of PhIP-HN²-O-Gluc [164].

$\mathrm{HONH}-\mathrm{A} \alpha \mathrm{C}$, the genotoxic metabolite of $\mathrm{A} \alpha \mathrm{C}$, also forms an $O$-linked Gluc conjugate, $O$-( $\beta$-D-glucosiduronyl)2-hydroxyamino-9H-pyrido[2,3-b]indole $\quad\left(\mathrm{A} \alpha \mathrm{C}-\mathrm{HN}^{2}-\mathrm{O}-\right.$ Gluc), as the primary conjugate produced by human liver 


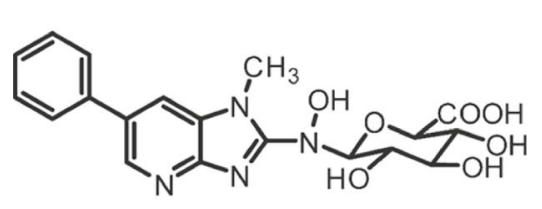

PhIP-HON²-Gluc

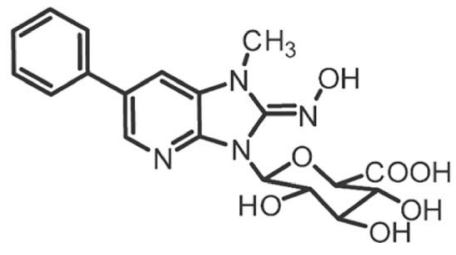

HON-PhIP-N3-Gluc

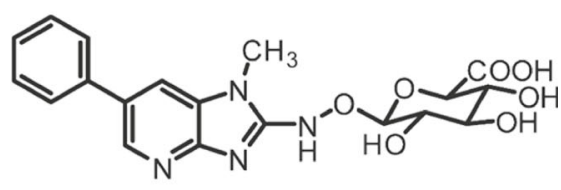

PhIP-HN²-O-Gluc

Fig. 5 Chemical structures of HONH-PhIP Gluc conjugates

microsomes and lesser amounts of $N^{2}$-( $\beta$-D-glucosiduronyl)-

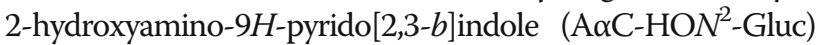
are formed [142, 160]. Recombinant UGT1A9 is the most catalytically efficient UGT isoform in producing $\mathrm{A} \alpha \mathrm{C}-\mathrm{H} N^{2}$ $\mathrm{O}-\mathrm{Gl}$ and has the lowest apparent $\mathrm{Km}(0.7 \mu \mathrm{M})$ of the UGTs assayed. Studies with human hepatocytes confirmed the preferred formation of $\mathrm{A} \alpha \mathrm{C}-\mathrm{HN}^{2}-\mathrm{O}-\mathrm{Gluc}$ over $\mathrm{A} \alpha \mathrm{C}-\mathrm{HON}^{2}$ Gluc [142].

The $\mathrm{A} \alpha \mathrm{C}-\mathrm{HN}^{2}-\mathrm{O}-\mathrm{Gl}$ conjugate is a biologically reactive metabolite that binds to DNA in vitro under physiological $\mathrm{pH}$ at $\sim 50$-fold higher levels than $\mathrm{HONH}-\mathrm{A} \alpha \mathrm{C}$; the PhIP$\mathrm{HN}^{2}$-O-Gluc binding to DNA was about 3-fold greater than for HONH-PhIP [142]. In contrast, the PhIP-HON ${ }^{2}$ Gluc and $\mathrm{A} \alpha \mathrm{C}-\mathrm{HON}^{2}$-Gluc are weakly bound to DNA [160]. Thus, UGT-mediated O-glucuronidation is a possible bioactivation mechanism for $\mathrm{HONH}-\mathrm{A} \alpha \mathrm{C}$ and HONH-PhIP. UGT-mediated Gluc conjugation of chemicals is considered a detoxication mechanism; however, UGTs contribute to the bioactivation of some NSAIDs to form acyl Gluc conjugates [165] and N-O-glucuronides of arylhydroxamic acids ( $N$-hydroxy- $N$-acetylarylamines), where the electrophilic nitrenium ion species can react with protein or DNA [166-168].

In one population-based case-control study investigating individuals who frequently ate cooked meat, subjects with genetic variations in UGT1A1 harboring functional variants with intermediate or low enzyme activity, based on genotype, were at greater risk for colon cancer than high activity genotype individuals [169]. Individuals with low UGT1A1 functional activity may be at elevated risk because they less efficiently detoxicate HAA or PAH procarcinogens ingested from cooked meats than subjects with rapid UGT1A1 activity. However, the authors reported a paradox with UGT1A9. The strongest association for colon cancer risk in meat-eaters was observed among the high/intermediate UGT1A9 genotype, indicating that either poor genotype-phenotype correlation or some other chemical(s) formed in pan-fried red meat other than HAAs was driving the association. Our biochemical data on UGT1A9 activity offers an alternative interpretation. The high/intermediate UGT1A9 genotype individuals can bioactivate HONH-HAAs, such as
$\mathrm{HONH}-\mathrm{A} \alpha \mathrm{C}$ and $\mathrm{HONH}-\mathrm{PhIP}$, to produce HAA- $\mathrm{HN}^{2}$ $O$-Gluc metabolites in the liver, followed by their elimination via the bile to the gastrointestinal tract, where ensuing binding to colonic DNA can occur [160]. Given the prominent role of UGTs in HAA metabolism, further studies are warranted to assess UGT genetic polymorphisms in the cancer susceptibility of meat-eaters.

The Glutathione S-transferases (GST) are another important class of enzymes involved in the detoxication of many endogenous electrophiles and xenobiotics, including HAAs [170]. Human GST enzymes are classified as Alpha (GSTA), Mu (GSTM), Omega (GSTO), Pi (GSTP), Theta (GSTT) and Zeta (GSTZ) [171]. Glutathione (GSH) reacts non-enzymatically or catalyzed by GST to detoxify HONH-HAAs and their reactive N-O-esters. GSH reacts with the nitroso metabolite of Glu-P-1 in vitro to form glutathione sulfinamide and sulfonamide adducts [172]. GSTs in rat liver catalyzed the formation of three GSH conjugates with the $N$-hydroxylated metabolite of Trp-P-2 (Fig. 7). One conjugate was a potent bacterial mutagen and assigned as the semimercaptal conjugate; detoxicated products were characterized as a GSH-linked sulfinamide, and a stable S-C conjugate formed at the $\mathrm{C}-4$ atom of Trp-P-2 [173]. The GSTA and GSTP class isoforms of GST inhibited DNA binding of activated HONH-PhIP metabolites in cell-free systems. An incubation mixture containing $N$-acetoxy-PhIP, GSH, and GSTA1-1 produced oxidized GSH (GSSG) and reduced PhIP. GSH conjugates were not detected, suggesting that a nucleophilic displacement mechanism was involved in the deactivation of $\mathrm{N}$ acetoxy-PhIP [174]. A short-lived GSH sulfenamide conjugate of PhIP may have formed and undergone a reaction with another GSH molecule to produce PhIP and GSSG (Fig. 7). GSTP-1 inhibited DNA binding of ATPdependent metabolite(s) of HONH-PhIP [175]. The LNCaP human prostate adenocarcinoma cell line genetically modified to express GST P-1 also diminished HONHPhIP DNA binding in intact cells $[174,175]$. GSH depletion in primary rat hepatocytes by L-buthione-sulfoximine resulted in a 15-fold increase in PhIP-DNA adducts [176], and GSH depletion in vivo in rats resulted in a 5-fold increase in hepatic PhIP-DNA adducts [177]. The GST- 


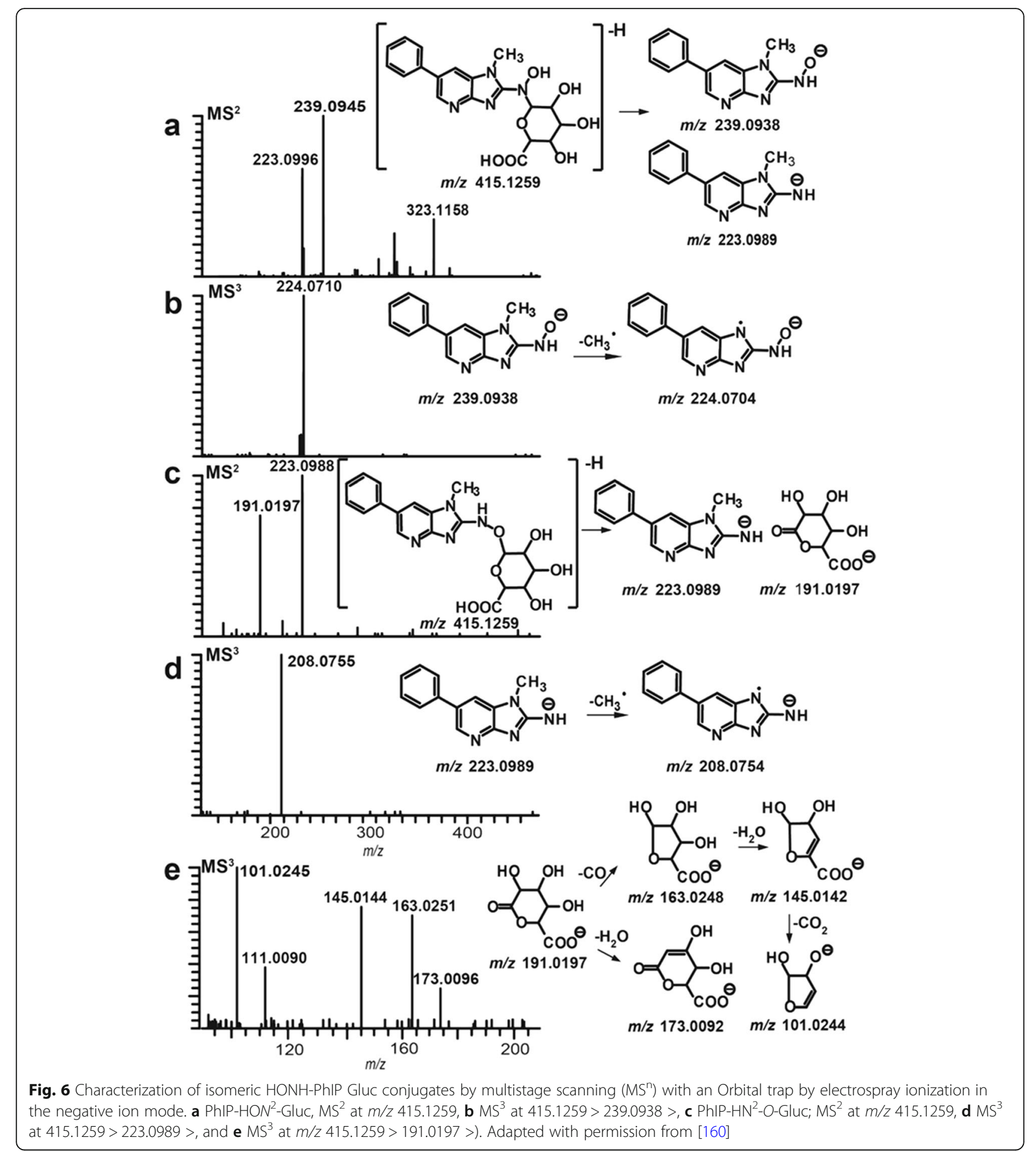

dependent detoxication pathway may be a critical determinant for the organ specificity of PhIP-carcinogenesis in rodents and possibly humans [174, 178]. Human liver cytosol contains high levels of GST A1-1 that catalyzes the GST-mediated detoxication of $\mathrm{N}$-acetoxy-PhIP; however, the colon cytosol contains about 100-fold lower levels of the GSTA1-1 and does not display GSTmediated inhibition of $\mathrm{N}$-acetoxy-PhIP binding to DNA $[174,176,179]$. The high levels of hepatic GSTA1-1 expression may explain the lower levels of PhIP-DNA adduct formation in the liver compared to that in the pancreas, prostate, or colorectal tissue of rats which 


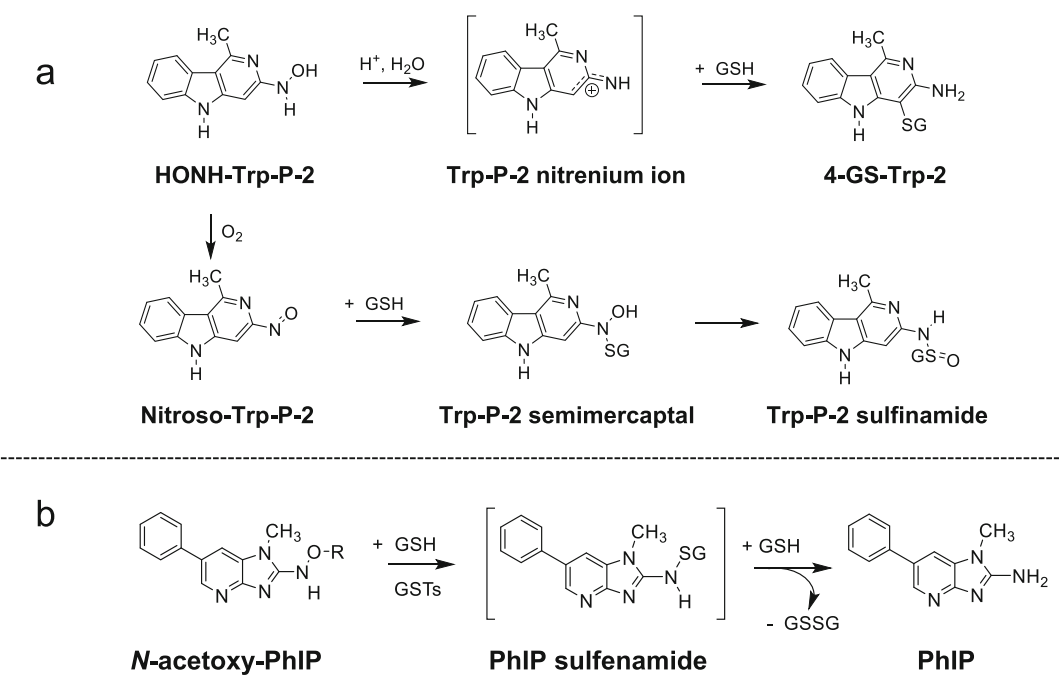

Fig. 7 Reaction pathways of a HONH-Trp-P-2 and $\mathbf{b} \mathrm{N}$-acetoxy-PhIP intermediates with GSH and GSTs
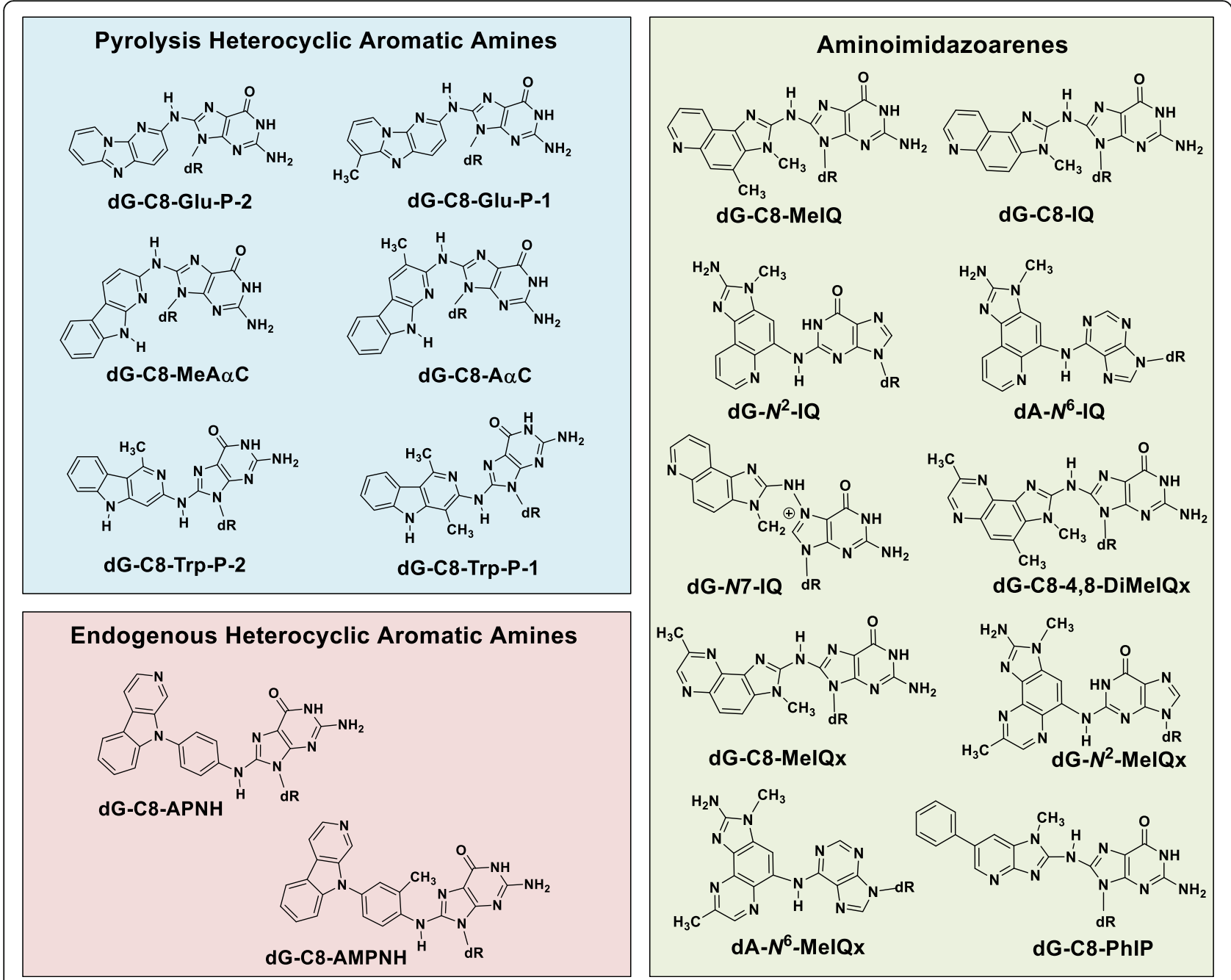

Fig. 8 Structures of HAA-DNA adducts 
lack this enzyme [177]. Thus far, HAA mercapturic acid conjugates have not been identified in the urine of experimental laboratory animals or humans.

\section{HAA macromolecule adduct formation HAA-DNA adducts}

The structures of prominent HAA-DNA adducts are shown in Fig. 8. HAA-DNA adducts were originally prepared through biomimetic reactions of the $\mathrm{HONH}-\mathrm{HAA}$ intermediates with deoxynucleosides or DNA with ketene gas, or acetic anhydride, to produce reactive $\mathrm{N}$-acetoxy intermediates. The overall yield of DNA adduct formation with deoxynucleosides or DNA by biomimetic reactions is usually several percent or lower $[49,63,152$, 180-182]. $N$-Hydroxy-HAAs bind primarily to the C8 atom of dG. Minor reaction products of HONH-IQ and HONH-MeIQx also occur at the $N^{2}$ atom of dG and the C8 and $N^{6}$ atoms of dA [180, 182, 183]. However, the C8 position of dG is only weakly nucleophilic. Studies with structurally related aromatic amines proposed that dG-C8-arylamine adducts are rearrangement products of ylide intermediates of dG-N7-arylamine hydrazine adducts (Fig. 9) [184]. dG-C8-HAA adduct formation may occur through the same mechanism. In support of this chemistry, a proposed hydrazine-linked $\mathrm{dG}$ adduct of IQ, $\quad N^{2}$-(2'-deoxyguanosin-7-yl)-IQ (dG-N7-IQ) was identified and characterized by mass spectrometry [182] (Fig. 8). Based on studies with 4-nitroquinoline 1-oxide, cationic dG-N7-arylamine adducts also can undergo depurination to produce DNA strand breaks or undergo solvolysis to produce 8-oxo-2'-deoxyguanosine (8-oxodG) $[185,186]$. These chemical mechanisms may explain dG-C8-HAA formation and HONH-HAA-mediated DNA strand breakage and 8-oxo-dG formation (Fig. 9) [187].

More recently, nonbiomimetic approaches using the Buchwald-Hartwig arylamination have been employed to synthesize multiple dG-C8-HAA adducts and 5-(2'deoxyguanosin- $N^{2}$-yl)-IQ (dG- $N^{2}$-IQ) in larger scale [188-190]. Only several studies have investigated HAADNA structure and the fidelity of polymerases during translesional synthesis. An NMR study on the solution structure of dG-C8-PhIP situated within the oligonucleotide duplex d(CCATCGCTACC):d(GGTAGCGATGG) reported the PhIP adduct induced conformational exchanges in the DNA structure, existing between the major

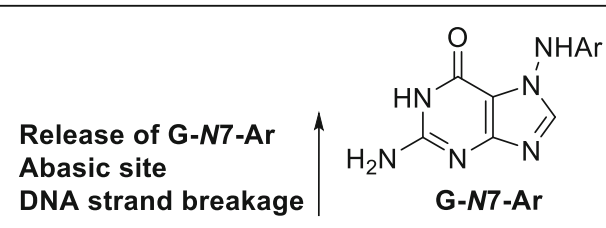

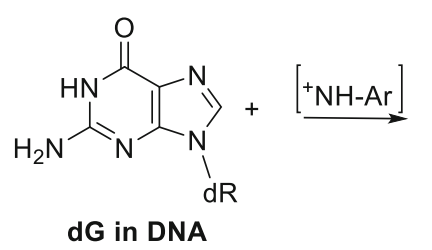<smiles></smiles>

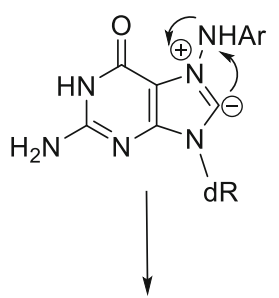

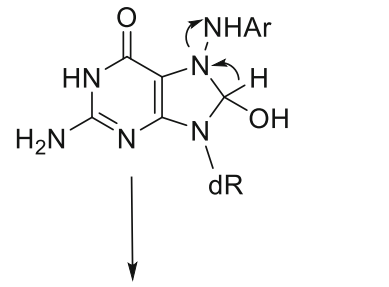<smiles>Nc1nc2c(nc(N[AlH2])n2[18O])c(=O)[nH]1</smiles><smiles>[R10]Cn1c(=O)[nH]c2c(=O)[nH]c(N)nc21</smiles>

Fig. 9 Proposed mechanism of dG-C8-Ar adduct formation, induction of abasic sites, DNA strand breakage, and 8-oxo-dG formation. Ar represents an aromatic amine or HAA 
base-displaced intercalative structure and a minor external groove-binding structure [191, 192]. Similar conformational distortions were observed for DNA adducts of aromatic amines, which impact codon base pairing and implicated in mechanisms of mutagenesis [193]. Studies on the fidelity of several human polymerases during translesional syntheses across $N$-( $2^{\prime}$-deoxyguanosin-8-yl)-PhIP (dG-C8-PhIP), N-(2'-deoxyguanosin-8-yl)-IQ (dG-C8$\mathrm{IQ})$, and 5-(2'-deoxyguanosin- $N^{2}$-yl)-IQ (dG- $\left.N^{2}-\mathrm{IQ}\right)$ adducted oligomers showed the polymerase activities, and catalytic efficiencies were dependent on both DNA adduct structures and sequence contexts [194-197].

\section{HAA-DNA adduct formation in experimental laboratory animals}

HAA-DNA adducts have been detected in multiple tissues of experimental laboratory animals, employing ${ }^{32} \mathrm{P}$-postlabeling, liquid chromatography/mass spectrometry (LC/MS), or accelerator mass spectrometry (AMS), see citations in [49, 63, 198-201]. One study on DNA adduct persistence showed that dG- $N^{2}$-IQ (Fig. 8), a minor DNA adduct formed in vitro with calf thymus DNA modified with $N$-acetoxy-IQ [180], becomes the prominent lesion in slowly dividing tissues of rats and nonhuman primates that underwent chronic treatment with IQ, indicating preferential repair of the major dG-C8-IQ adduct [202, 203]. Thus, the minor dG- $N^{2}$-IQ may have a significant role in the tumorigenic properties of IQ.

\section{HAA-DNA adduct formation in human tissues}

The putative dG-C8-MeIQx adduct was detected in the colon and kidney of individuals at levels of several adducts per $10^{9}$ nucleotides when assayed by ${ }^{32} \mathrm{P}$-postlabeling [204]. dG-C8-APNH was detected in human lung and stomach tissue by LC/MS at levels ranging from 0.6 to 14 adducts per $10^{8}$ nucleotides [44]. A gas chromatography/negative ion chemical ionization-mass spectrometry assay, following the hydrolysis of presumed dG-C8-HAA adducts formed with DNA, was employed to measure adducts in DNA of the colorectal mucosa and lymphocytes of cancer subjects; the levels of the putative dG-C8-PhIP adduct were in the range of several adducts per $10^{8}$ DNA bases $[205,206] .{ }^{32}$ P-Postlabeled lesions attributed to dG-C8-PhIP were detected in exfoliated breast epithelial cells in milk in 30 out of 64 lactating mothers [207]. The mean adduct level was 4.7 adducts $/ 10^{7}$ nucleotides. In another study, PhIPDNA adducts were detected by immunohistochemistry (IHC) in mammary tissue of $82 \%$ of the women with breast cancer $(N=106)$ and $71 \%$ of the tissue samples of the healthy control patients $(N=49)$ [208]. A very high percentage of pancreas and prostate biospecimens were also positive for PhIP-DNA adducts assayed by
IHC $[209,210]$. The detection limit of PhIP-DNA adducts by IHC is several adducts per $10^{7}$ nucleotides, implying most patients harbored PhIP-DNA adducts at relatively high levels.

The frequent detection of PhIP-DNA adducts at high levels in human tissues is alarming and implies that PhIP-DNA adduct formation occurs with far greater efficiency in humans exposed to ppb levels of dietary PhIP than in rodents given high, carcinogenic doses of PhIP (10 - $50 \mathrm{mg} / \mathrm{kg}$ body weight). However, the biomarker data obtained by ${ }^{32} \mathrm{P}$-postlabeling and $\mathrm{IHC}$ are controversial: both screening methods are non-selective and fail to provide confirmatory spectral data, and thus, the identities of the lesions are equivocal. PhIPDNA adducts measured by AMS in the breast tissue of female cancer patients who had received a dose of $\left[{ }^{14} \mathrm{C}\right] \mathrm{PhIP} \quad(20 \mu \mathrm{g}$ PhIP/70 kg body weight $)$ by oral administration before surgery ranged from 26 to 480 adducts $/ 10^{12}$ nucleotides [211], or nearly 1000 - to 10 , 000 -fold lower than the levels of adducts reported by the IHC or ${ }^{32} \mathrm{P}$-postlabeling techniques $[207,208]$. Our laboratory employed a specific and sensitive LC/ MS ion trap method to screen non-tumor-adjacent mammary tissue for DNA adducts of PhIP [212]. Only 1 of 70 biopsy samples obtained from breast cancer patients from Minneapolis harbored the dGC8-PhIP adduct. The level was three adducts per $10^{9}$ nucleotides, a level that is 100 -fold lower than the mean level of PhIP adducts reported in other cohorts monitored by IHC or ${ }^{32} \mathrm{P}$-postlabeling methods. Our laboratory also reported a much lower detection frequency and lower adduct levels of dG-C8-PhIP in human prostate specimens assayed by LC/MS than the IHC assays [213, 214].

HAA-DNA adduct levels and frequency of detection may significantly differ between cohorts and are dependent on the cohort's dietary preferences for consuming well-done cooked meats and the analytical methods employed to measure DNA adducts. The IHC assay detected PhIP-DNA adducts at high frequency, occurring at levels at or above several adducts per $10^{7} \mathrm{nu}$ cleotides in PC patients treated at the Henry Ford Health System in Detroit, MI [210, 215]. In contrast, our method employing high-resolution accurate mass spectrometry reported a significantly lower detection frequency of dG-C8-PhIP (13 out of 164 patients) in PC patients treated at the Department of Urology, University of Minnesota Medical School, Minneapolis, MN (Fig. 10) [213, 214, 216]. The dG-C8-PhIP levels ranged between 0.3 to 12 adducts per $10^{8}$ nucleotides. DNA adducts of other prevalent HAAs were not detected [214]. The large discrepancy in detection frequency and PhIP adduct levels in the prostate (and breast) obtained by $\mathrm{IHC}$ and ${ }^{32} \mathrm{P}$-postlabeling, as opposed to the precise 


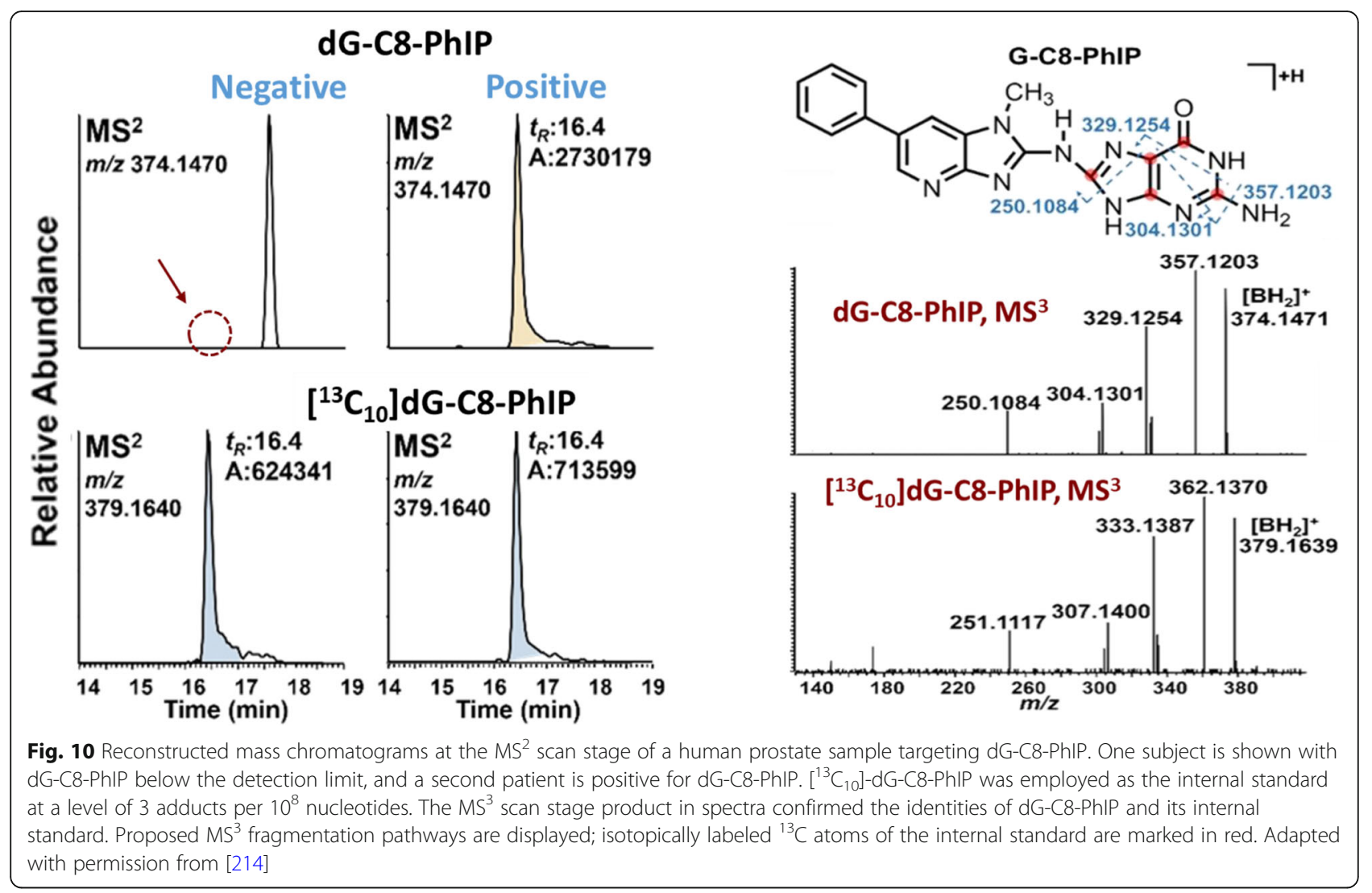

AMS or LC/MS methods, suggests that the biochemical assays are non-specific and detect a variety of lesions in addition to or other than dG-C8-PhIP. These findings call for further studies, where DNA adduct levels detected by biochemical and MS methods are compared directly for the same tissue samples. We believe that such direct comparisons will demonstrate the necessity to employ specific MS methods to measure DNA adducts in human population studies.

\section{HAA blood protein adduct formation}

Carcinogen adducts with hemoglobin $(\mathrm{Hb})$ and serum albumin (SA) have been characterized for many classes of carcinogens, including aromatic amines, HAAs, polycyclic aromatic hydrocarbons (PAHs), $\mathrm{AFB}_{1}$, and other alkylating agents [49, 217223]. The Hb lifetime is 125 days, and the half-life of SA is $20-25$ days in humans [217, 224]. Thus, the steady-state levels of stable $\mathrm{Hb}$ and $\mathrm{SA}$ carcinogen adducts may reach, respectively, about 60- and 29fold higher after chronic exposure than after a single dose. Several blood protein carcinogen adducts have served as long-lived biomarkers in human studies [49, 217-223].

\section{HAA hemoglobin adducts}

Structurally related arylamines undergo metabolism by hepatic cytochrome P450 to form the arylhydroxylamine metabolites, which undergo systemic circulation through the blood [225]. Once taken up by the erythrocytes, the arylhydroxylamines can undergo a co-oxidation reaction with oxy-hemoglobin $\left(\mathrm{HbO}_{2}\right)$ to form methemoglobin (met- $\mathrm{Hb})$ and the arylnitroso intermediates. Arylnitroso compounds can undergo redox cycling with NADPH reductase in the erythrocyte to reform the arylhydroxylamines, ultimately producing methemoglobinemia (Fig. 11). Some arylnitroso intermediates also selectively react with $\mathrm{Hb} \beta-\mathrm{Cys}^{93}$ to form $\mathrm{Hb}$ arylsulfinamide adducts. The biochemistry of arylamine metabolism has been exploited to biomonitor several AAs, including aniline (ANL), o-toluidine, 2-naphthylamine, and 4-aminophenyl (4-ABP) through their $\mathrm{Hb}$ arylsulfinamide adducts in humans [227, 228]. In contrast to aromatic amines, most HAAs studied do not efficiently bind to rodent or human $\mathrm{Hb}$ in vivo [49, $201,229,230]$. We compared the reactivity of the synthetic $N$-hydroxy metabolites of PhIP, MeIQx, A $\alpha \mathrm{C}$, ANL, and 4ABP with purified human $\mathrm{HbO}_{2}$. Phenylhydroxylamine (HONH-ANL), N-hydroxy-4-aminobiphenyl (HONH-4$\mathrm{ABP}$ ), and $\mathrm{HONH}-\mathrm{A} \alpha \mathrm{C}$ rapidly oxidized $\mathrm{HbO}_{2}$ to met- $\mathrm{Hb}$, forming arylamine and $\mathrm{A} \alpha \mathrm{C}$ sulfinamide adducts with a 


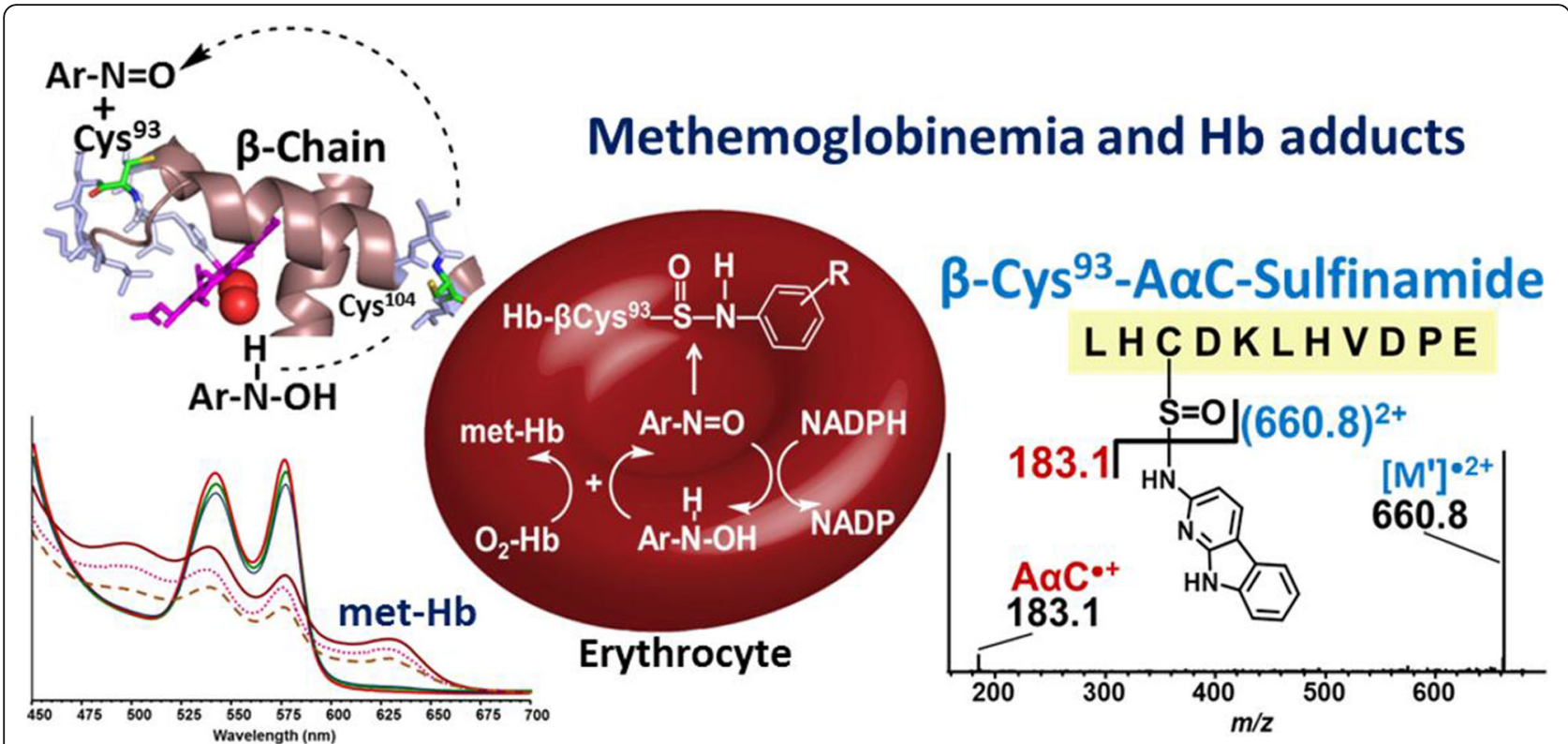

Fig. 11 Co-oxidation of $\mathrm{HbO}_{2}$ by $\mathrm{N}$-hydroxylated aromatic amines and HAAs in human RBCs and met-Hb formation. The mass spectrum of the $\mathrm{AaC}$ sulfinamide formed at the $\beta$-Cys ${ }^{93}$ of $\mathrm{Hb}$ was acquired by ion trap mass spectrometry employing electrospray ionization in the positive ion mode. The AaC-modified $\mathrm{Hb}$ was digested with $\mathrm{Glu}-\mathrm{C}$, and the peptide sequence encompassing the AaC sulfinamide adduct formed at $\mathrm{Hb} \beta$ $\mathrm{Cys}^{93}$ is reported. Adapted with permission from [226]

concomitant decrease in the free $\mathrm{Hb} \beta$-Cys ${ }^{93}$ thiol content of $\mathrm{Hb}$ [226]. In contrast, HONH-PhIP and HONH-MeIQx did not induce oxidation of $\mathrm{HbO}_{2}$, the number of titratable thiols remained unchanged from the control, and chemical modification of the $\mathrm{Hb} \beta-\mathrm{Cys}^{93}$ with either carcinogen was negligible. Like HONH-ANL and HONH-4-ABP, HONH$\mathrm{A} \alpha \mathrm{C}$ underwent co-oxidation with $\mathrm{HbO}_{2}$ in isolated human erythrocytes to produce methemoglobinemia, while HONH-PhIP and HONH-MeIQx did not (Fig. 11). Molecular modeling studies showed that the HONH-AA or
HONH-HAA substrates were too distant to interact with $\mathrm{HbO}_{2}$ and form met-Hb. The different conformational changes in flexible helical and loop regions around the heme pocket induced by the HONH-AAs or HONH-HAAs may explain the different proclivities of these chemicals to induce methemoglobinemia [226]. $\mathrm{HONH}-\mathrm{A} \alpha \mathrm{C}$ formed the $\mathrm{Hb}$ sulfinamide adduct in erythrocytes at greater levels than $\mathrm{HONH}-4$ $\mathrm{ABP}$, suggesting that the $\mathrm{A} \alpha \mathrm{C} \mathrm{Hb}$ sulfinamide may

Table $4 \mathrm{Hb}$ adducts of 4-ABP, AaC, cotinine levels, and smoking status ${ }^{\mathrm{a}}$

\begin{tabular}{|c|c|c|c|c|c|}
\hline & $\begin{array}{l}\text { 4-ABP-Hb } \\
\text { (pg/g Hb) }\end{array}$ & $\begin{array}{l}\text { AaC-Hb } \\
(\mathrm{pg} / \mathrm{g} \mathrm{Hb})\end{array}$ & $\begin{array}{l}\text { Cotinine } \\
\text { (ng/mL) }\end{array}$ & Cigarettes per day & Smoking years \\
\hline Commercial Blood & $22.9 \pm 0.2 b^{b}$ & $4.3 \pm 2.4$ & $n \cdot a^{c}$ & n.a & n.a \\
\hline R01 & $29.8 \pm 6.9$ & $5.6 \pm 0.8$ & 0.13 & 0 & 0 \\
\hline R03 & $23.8 \pm 6.9$ & $4.6 \pm 0.6$ & 0.13 & 0 & 0 \\
\hline R05 & $21.8 \pm 2.8$ & $5.6 \pm 1.1$ & 0.13 & 0 & 0 \\
\hline R02 & $189 \pm 8.5$ & $16.2 \pm 1.9$ & 164 & 30 & 42 \\
\hline R04 & $71.4 \pm 8.9$ & $16.1 \pm 1.0$ & 224 & 20 & 25 \\
\hline R06 & $125 \pm 6.8$ & $26.8 \pm 2.5$ & 228 & 21 & 33 \\
\hline R07 & $134 \pm 7.5$ & $24.5 \pm 0.8$ & 210 & 30 & 32 \\
\hline R08 & $71.3 \pm 1.6$ & $17.3 \pm 0.7$ & 86 & 25 & 30 \\
\hline R09 & $162 \pm 7.8$ & $15.5 \pm 0.9$ & 108 & 70 & 53 \\
\hline R10 & $90.4 \pm 3.7$ & $6.6 \pm 0.6$ & 55 & 25 & 30 \\
\hline
\end{tabular}

${ }^{a}$ reproduced with permission from [234]

${ }^{\mathrm{b}}$ mean \pm standard deviation

cn.a., not analyzed 
be a promising biomarker to assess $\mathrm{A} \alpha \mathrm{C}$ exposure in humans [226].

$\mathrm{A} \alpha \mathrm{C}$ is present in mainstream tobacco smoke at 25 100-fold higher amounts than 4-ABP [23, 231-233]; however, the mean level of the 4-ABP-Hb adduct is 7.4fold greater than the mean level of the $\mathrm{A} \alpha \mathrm{C}-\mathrm{Hb}$ adduct in smokers (Table 4) [234]. The higher level of 4-ABP$\mathrm{Hb}$ adduct formation is not attributed to the superior reactivity of $\mathrm{HONH}-4-\mathrm{ABP}$ with $\mathrm{HbO}_{2}$ since $\mathrm{HNOH}-\mathrm{A} \alpha \mathrm{C}$ induces more methemoglobinemia in erythrocytes in vitro and forms higher levels of the $\mathrm{Hb}$-sulfinamide than does HONH-4-ABP [226]. Higher 4-ABP Noxidation rates do not appear to explain the elevated levels of 4-ABP-Hb formation as the hepatic microsomal $\mathrm{N}$-oxidation rates of both compounds are similar [108, 235]. A $\alpha \mathrm{C}$ undergoes extensive metabolism by primary human hepatocytes to produce multiple phase I and phase II metabolites [130], whereas the pathways of metabolism of 4-ABP in human hepatocytes are incompletely characterized [236]. We postulate that the amount of $\mathrm{HONH}-4-\mathrm{ABP}$ circulating in the blood and delivered to the erythrocyte is far greater than $\mathrm{HONH}-$ $\mathrm{A} \alpha \mathrm{C}$, resulting in proportionately higher levels of 4ABP-Hb adducts [228, 237]. Neither 4-ABP nor A $\alpha C$ DNA adducts were detected in white blood cells of these smokers (limit of quantification 3 adducts per $10^{9}$ nucleotides) [234].

\section{HAA serum albumin adducts}

SA is the most abundant serum protein in humans. It is synthesized in the hepatocyte and released from the endoplasmic reticulum as a mature protein with 585 amino acids after cleavage of the signal peptide sequence [238]. Albumin is critical in maintaining the colloid osmotic pressure and transporting hormones, fatty acids, and xenobiotics, including therapeutic drugs, environmental pollutants, and carcinogens [239]. Several classes of carcinogens, including many HAAs and $\mathrm{AFB}_{1}$, react poorly with $\mathrm{Hb}[201,229,230,240]$, possibly because the reactive intermediates do not escape from the hepatocyte. However, SA carcinogen adducts can form in the hepatocyte, where metabolic activation occurs for many genotoxicants, including $\mathrm{HAAs}$ and $\mathrm{AFB}_{1},[64$, 108, 240, 241]. Thus, monitoring SA adducts of certain carcinogens may be feasible when they fail to bind to $\mathrm{Hb}$.

The $\mathrm{Cys}^{34}$ is one of 35 conserved cysteine residues in SA across species [239]. Thirty-four of these cysteines are involved in 17 disulfide bonds. The single unpaired $\mathrm{Cys}^{34}$ is present either as a free thiol or in an oxidized form as mixed disulfide linkages with low molecular weight thiols [242-244]. The SA-Cys ${ }^{34}$ resides in a crevice in a microenvironment close to three ionizable residues, $\mathrm{Asp}^{38}, \mathrm{His}^{39}$, and $\mathrm{Tyr}^{84}$, resulting in an unusually low $\mathrm{pKa}$ value of $\sim 6.5$ for the $\mathrm{Cys}^{34}$ thiol compared to $\mathrm{pKa}$ values of about 8.0-8.5 for Cys thiols in many other proteins and explain the high reactivity of SA$\mathrm{Cys}^{34}$ [245-248]. The scavenging properties of the SA$\mathrm{Cys}^{34}$ with xenobiotic electrophiles are well documented [220, 221]. N-Oxidized metabolites of MeIQx, PhIP, and IQ form sulfenamide or sulfinamide adducts at the Cys ${ }^{34}$ of rodent or human SA [230, 249-251].

The SA-Cys ${ }^{34}$ is a primary binding site of HONH$\mathrm{PhIP}$ in vitro and in vivo in humans, occurring as a sulfinamide (Fig. 12a) [253-256]. We investigated the kinetics of PhIP-SA adduct formation in volunteers on a semi-controlled meat feeding study for 4 weeks (Fig. 12b) [252]. PhIP-SA adduct levels were low during the threeweek pre-feeding phase but increased during the fourweek meat diet. Thus, PhIP-SA adduct formation proves PhIP underwent bioactivation in vivo. However, the PhIP-SA adduct declined rapidly, decreasing by $96 \%$ two weeks after completing the meat diet, signifying that the PhIP-Cys adduct is unstable and probably unsuitable for biomonitoring subjects on free-choice diets. The PhIPSA adduct levels varied over 550-fold among the subjects after four weeks of a meat diet; in contrast, the urinary Gluc metabolites of HONH-PhIP in these subjects only varied by 2 -fold $[213,257]$. Correlations were not seen between PhIP-SA adduct levels and the amount of PhIP accrued in hair $(P=0.13)$, the amounts of $\mathrm{N}$ oxidized urinary metabolites of PhIP $(P=0.66)$, or caffeine CYP1A2 activity $(P=0.55)$, a key enzyme involved in PhIP metabolism [252]. PhIP has multiple metabolic fates that can obscure the relationship between urinary HONH-PhIP-Gluc levels and PhIP-SA adducts [49]. The large intraindividual variations of CYP1A2 phenotype and inconsistent responses to CYP1A2 inducers also obscured the relationship between CYP1A2 phenotype and PhIP-SA adduct levels [257].

PhIP adducts also formed at the sole $\operatorname{Trp}^{214}$ of SA in human plasma treated in vitro with $N$-acetoxy-PhIP [255], recovered as $\mathrm{AW}^{*}[\mathrm{PhIP}]$ or $\mathrm{W}^{*}[\mathrm{PhIP}]$, respectively, in tryptic or pronase digests (Fig. 13). Another adduct was detected at His(s) following pronase digestion [255]. Trp and His adducts form at $\sim 10$-fold lower levels than PhIP-SA-Cys ${ }^{34}$, but these adducts are stable linkages and may accumulate during chronic exposure to PhIP and prove pivotal as long-term biomarkers in biomonitoring of PhIP.

\section{Biomonitoring HAAs in hair}

Stable, long-lived biomarkers are still sought to improve exposure assessment of HAAs than the currently used FFQ [258, 259]. Human hair has served as matrices for biomonitoring a wide range of chemicals, including nicotine, drugs, and narcotics, and hormones [260-262]. Our laboratory and others have shown that once PhIP is 


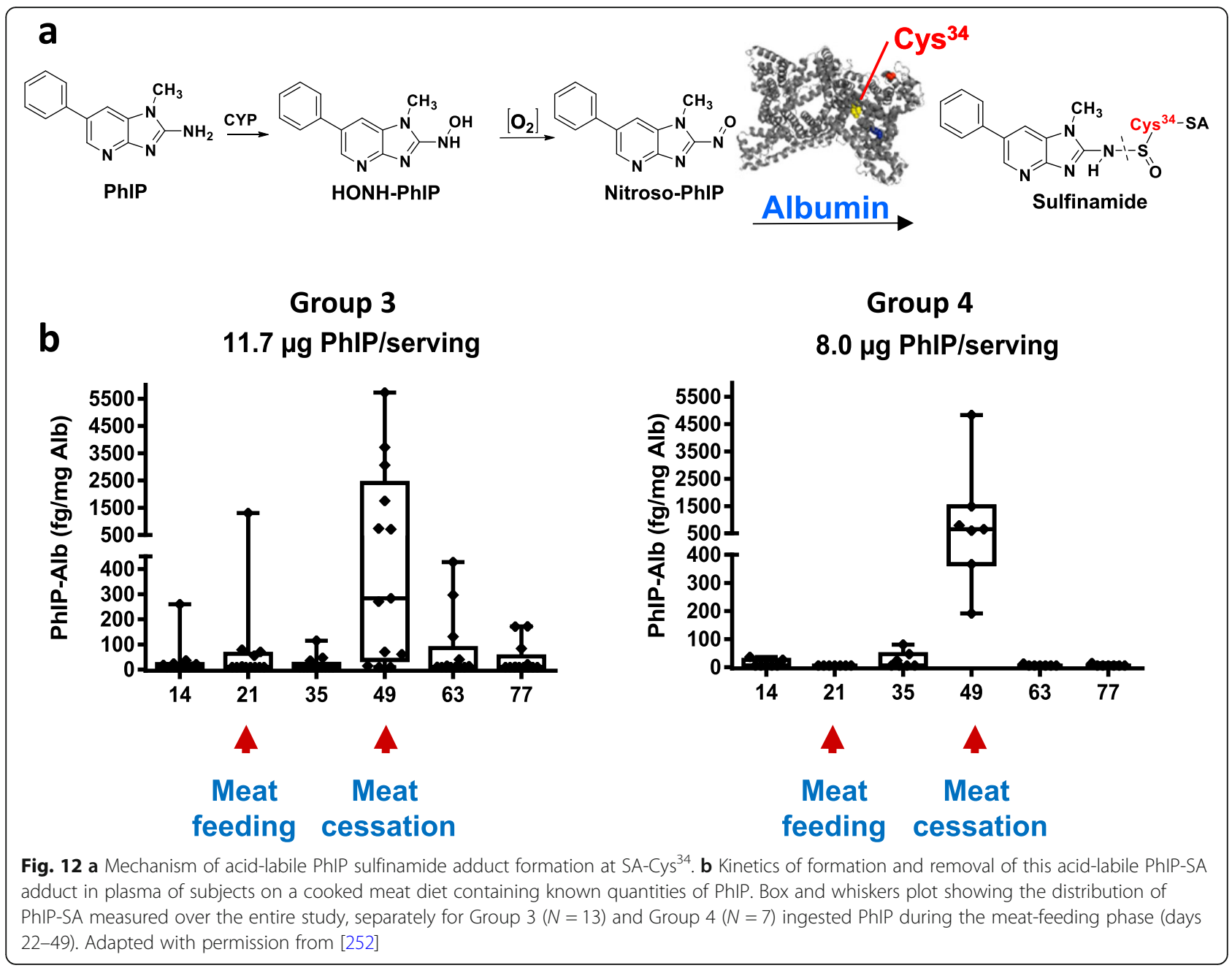

ingested, a small portion of the dose becomes entrapped in the hair follicle and incorporated into the newly grown hair shaft (Fig. 14) [259, 263, 264]. The degree of PhIP binding to hair is strongly correlated to the eumelanin content $[265,266]$. In contrast, other prevalent HAAs are sequestered in human hair at much lower levels. We established a tandem solid-phase extraction method followed by triple quadrupole mass spectrometry to quantify PhIP in hair, which requires only $25 \mathrm{mg}$ of hair [263, 267, 268]. PhIP was detected in the hair of omnivores but not vegetarians, demonstrating PhIP exposure is derived from a cooked meat diet (Fig. 14). Thereafter, we measured PhIP in the hair of nonsmokers who completed a semi-controlled diet of ground beef cooked to different doneness levels, reflecting a low or high concentration of PhIP in the range found in the American diet for 5 days a week for 1 month [268, 269]. Newly grown hair clipped from the back of the subjects' heads near the nape of the neck captured the previous 1-month exposure of PhIP. A substantial increase in PhIP hair levels occurred as a function of dose and normalizing for melanin content strengthened the correlation $(\rho=0.68, P<0.0001)$ (Fig. 15). However, CYP1A2 activity, based on the urinary caffeine metabolic ratio, had no impact on PhIP hair levels [267, 268]. The intraindividual CYP1A2 activity was highly variable over the time course of the feeding study and precluded stratification of subjects' CYP1A2 phenotype activity. PhIP hair levels may serve as a biomarker of exposure in epidemiologic studies investigating the association of cooked meat, HAAs, and cancer risk.

\section{Is PhIP a human prostate carcinogen?}

$\mathrm{PC}$ is the second most common cancer in men worldwide, with an estimated 1.1 million identified cases and 0.3 million PC-related deaths occurring by 2012 [270]. Studies of migrant populations show a significant increase in PC incidence and mortality rates in migrants from low prevalence PC regions following their relocation to a high prevalence of PC countries [271, 272]. Thus, environmental and/or dietary factors are involved in PC development. Several dietary components, 


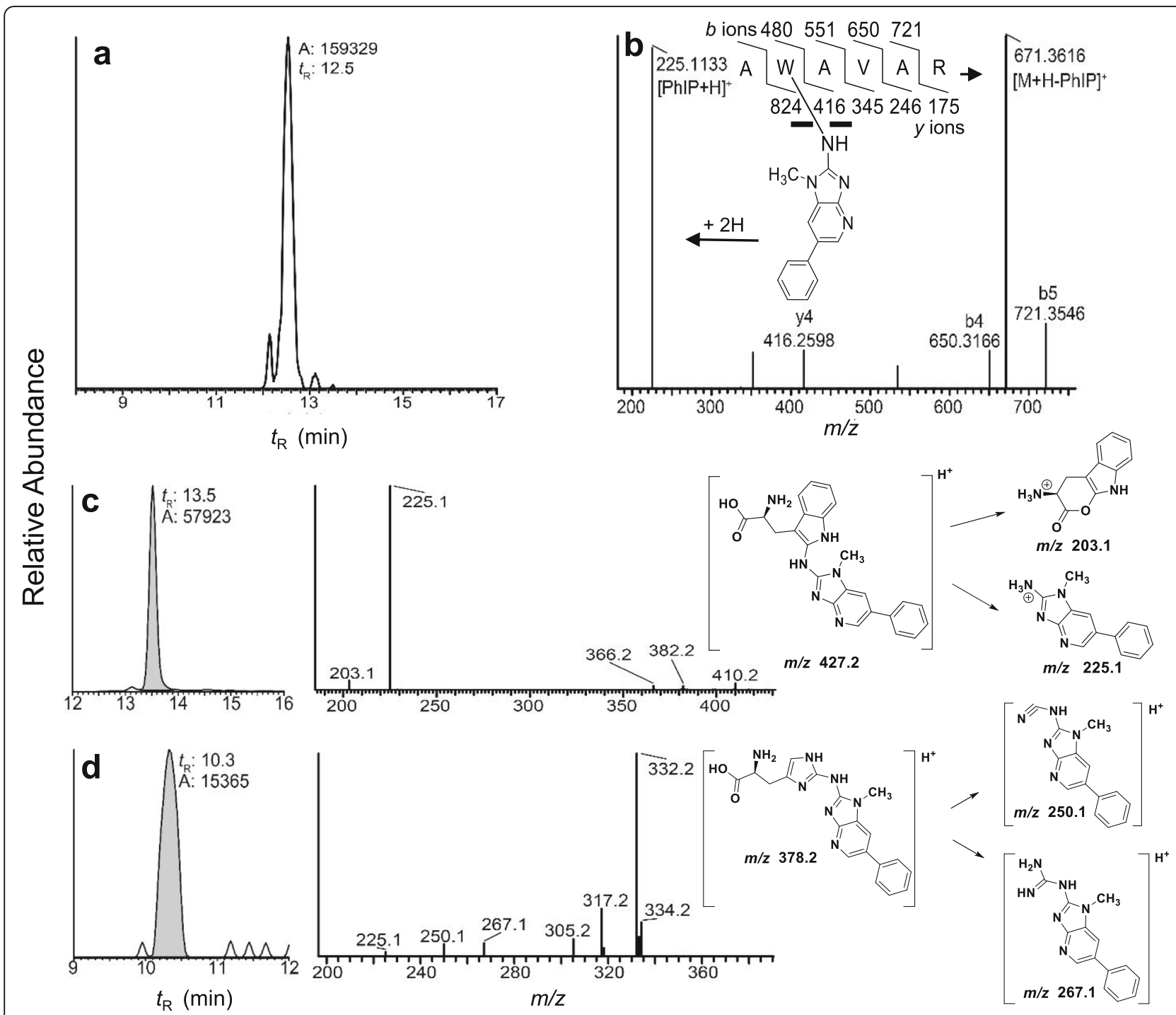

Fig. $13 \mathrm{~N}$-Acetoxy-PhIP modified human SA. Reconstructed mass chromatograms of a AW*[PhIP] AVAR $\left([M+2 H]^{2+} \mathrm{m} / \mathrm{z} 448.2385>\mathrm{m} / \mathrm{z} 225.1135\right.$, $\mathrm{m} / \mathrm{z}$ 671.3624; mass tolerance $2 \mathrm{ppm}), \mathbf{b} \mathrm{MS}^{2}$ product ion spectrum of $\left.\mathrm{AW} \mathrm{W}^{*} \mathrm{PhIP}\right] \mathrm{AVAR}\left([\mathrm{M}+2 \mathrm{H}]^{2+}\right.$, c Product ion spectrum of W*PhIP adduct following digestion with Pronase $\mathrm{E}$, and $\mathbf{d}$ Product ion ion spectrum of the $\mathrm{H}^{*} \mathrm{PhIP}$ adduct following digestion with Pronase $\mathrm{E}$ and proposed structures. The base peak at m/z 332.2 is attributed to the loss of formic acid. Adapted with permission from [255]

including high-fat, dairy products, alcohol, and red meats, are associated with PC risk [273], although the specific dietary compounds and their mechanisms of action remain undefined. Other PC risk factors include; age, family history, and ethnicity, with African-American (AA) men having a two-time higher risk than Caucasians [274].

The majority of epidemiologic studies investigating dietary consumption of well-done cooked meat in relation to various tumor sites trend to a positive association between cancer risk and well-done meat consumption $[87,88,275,276]$. Although, the data are inconsistent. A review and meta-analysis concluded that red meat intake was not linked to PC risk [277]; however, subgroup analyses revealed that frequent intake of well-done grilled or barbequed red meat was linked to aggressive PC [89, 278-281]. Thus, a health risk for PC may occur primarily by consuming well-done grilled or barbequed meats containing elevated levels of genotoxicants, including HAAs and PAHs [2, 282]. HAAs and PAHs are cancer initiators $[2,49,283,284]$, and some may serve as tumor promoters [278, 285, 286]. PhIP is the only cooked mutagen reported to induce PC in rodents [2, 13, 90]. The rodent carcinogenicity studies were conducted at doses of PhIP that are more than a million-fold higher than its daily intake in humans [2]. However, linear-dose 


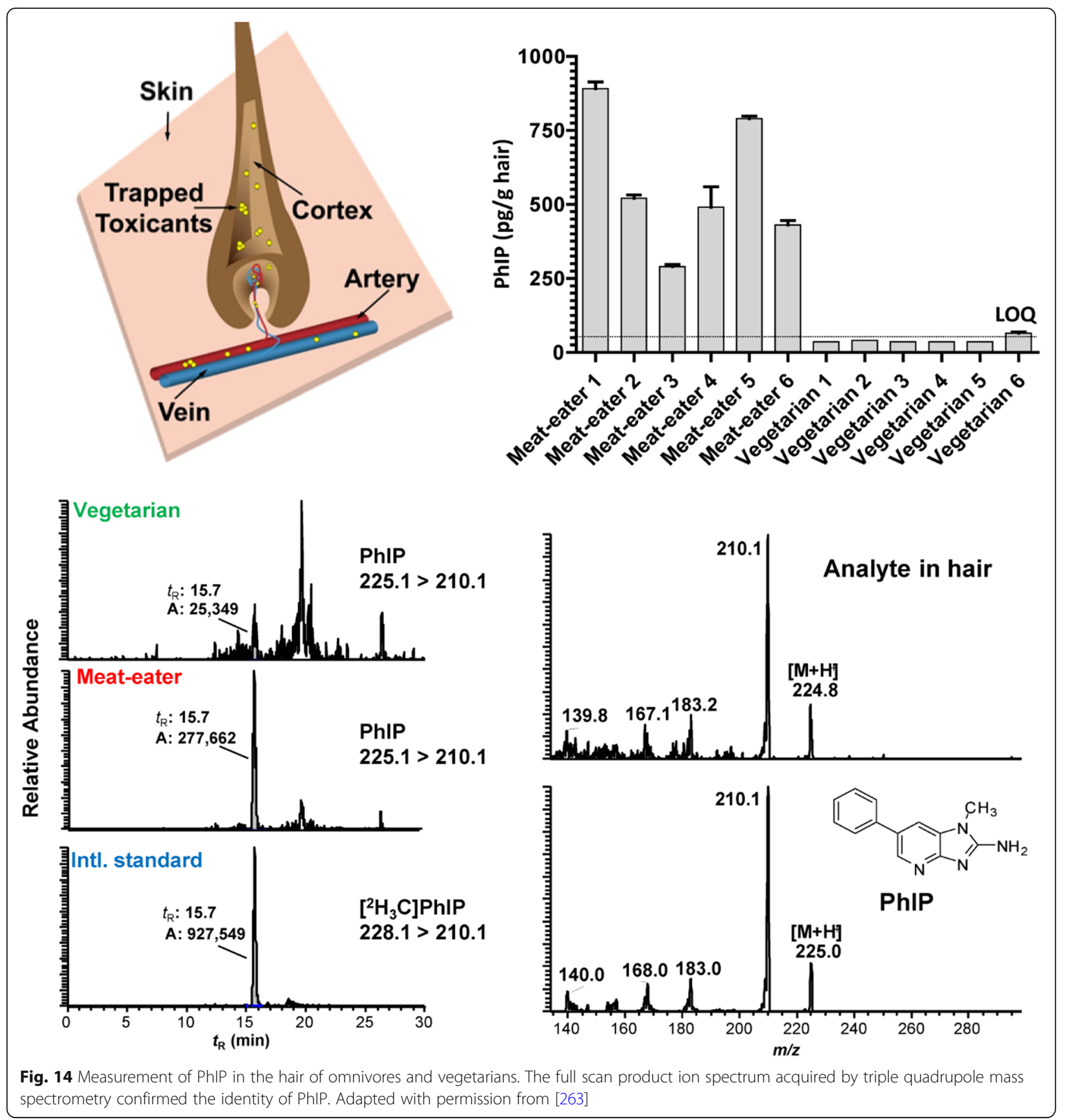

relationships exist between PhIP, MeIQx, and IQ, and DNA adduct formation in rodents down to human exposure levels, and DNA adducts of PhIP and MeIQx have been unambiguously identified in several human organs when assayed by specific AMS [201, 211, 287, 288], or LC/MS methods for dG-C8-PhIP in the prostate (Fig. 10).

The mortality rate of PC in AA men is twice as high as white men in the United States [289]. The elevated
PC risk is due to genetic factors, and exposures to hazardous chemicals in the environment and diet also may contribute to PC. AA men reportedly eat more welldone cooked meats and poultry containing PhIP than Caucasian men $[269,290]$. One study reported elevated levels of the prostate-specific antigen (PSA), a biomarker of PC risk, was associated with dietary PhIP intake in a prospective clinic-based study among AA men [289]. Does PhIP play a role in PC development, or is a 


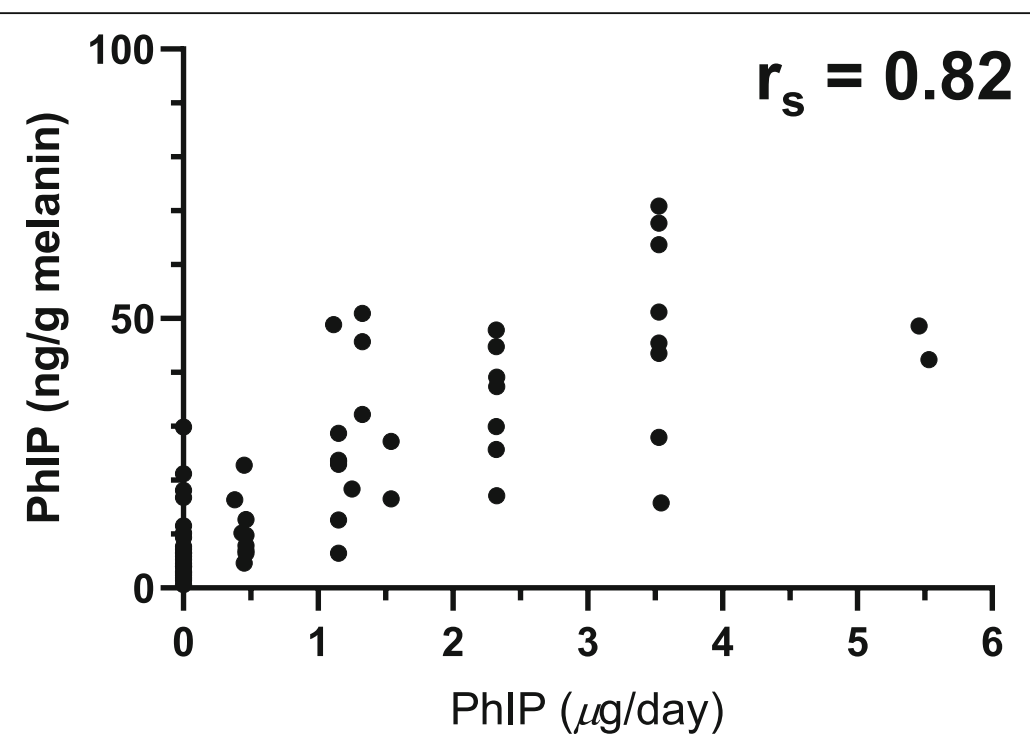

Fig. 15 Correlation of post-feeding PhIP scalp hair levels normalized for melanin in healthy volunteers with variable dietary PhIP intake 5 days a week over 4 weeks. The 0 value represents PhIP hair levels before commencing the feeding study. Adapted with permission from [268]

combination of the complex panel of chemicals present in cooked meat contributing to increased aggressive PC risk for AA men? The role of the well-done cooked meat diet in PC risk among different ethnic groups requires further investigation.

\section{PhIP genotoxicity in human prostate cells}

Our and other laboratories have studied HAA-DNA adduct formation and cytotoxicity in cancerous human prostate cell lines and primary prostate epithelial cells [175, 213, 291, 292]. We employed LNCaP cells, an androgen-sensitive prostate adenocarcinoma cell line derived from supraclavicular lymph node metastasis, for studies with HAAs. PhIP, MeIQx, and IQ did not form DNA adducts and were not toxic because the CYP1 enzymes, which bioactivate HAAs, are poorly expressed in LNCaP cells [213]. A $\alpha \mathrm{C}$ did form DNA adducts at low levels probably through bioactivation with other CYP or non-CYP oxidases expressed in LNCaP cells $[113,213]$ (Fig. 16). These data indicate that the CYP mediated Noxidation step of most HAAs likely occurs in the liver, followed by the systemic circulation of the HONHHAAs to the prostate, where further bioactivation by Phase II enzymes can occur [213]. The synthetic HONH-MeIQx, HONH-A $\alpha$ C, and HONH-IQ intermediates were not cytotoxic at a dose up to $10 \mu \mathrm{M}$, but HONH-PhIP induced a concentration- and timedependent cytotoxicity in LNCaP cells [213]. HONHPhIP underwent efficient bioactivation by NATs and SULTs, leading to DNA adduct formation at levels that were 20-fold higher than the other HONH-HAAs in LNCaP cells [213]. PhIP-DNA adducts formed in a dose-dependent manner down to levels of human exposure (Fig. 17) [213]. Similarly, HONH-PhIP formed DNA adducts at levels that were up to 100 -fold higher than those formed by HONH-MeIQx in normal prostate epithelial cells from the transition zone [291, 292]. HONHPhIP also induced unscheduled DNA synthesis and DNA single-strand breaks in primary human prostate epithelial cells at levels that were up to 100 -fold higher than HONH-MeIQx [293, 294].

dG-C8-PhIP, the sole known adduct formed with PhIP [152, 181, 295], induces CG>AT transversions followed by $\mathrm{CG}>\mathrm{TA}$ and $\mathrm{CG}>\mathrm{GC}$ transitions in rodents, transgenic target genes, and site-specific mutagenesis studies [62, 194, 296, 297]. The SBS8 mutation signature extracted from prostate adenocarcinomas reported in the Pan-Cancer Analysis of Whole Genomes (PCAWG) is of unknown etiology with transcriptional strand bias on CG>AT, suggesting mutations were induced by guanine adducts; the SBS18 mutational signature is linked to oxidative stress; SBS33 is of unknown etiology with strand bias on TA $>C G$, suggestive of thymidines adducts; and SBS37 and SBS41 are of unknown etiology [298]. Recently, a CG>AT pattern of PhIP-induced mutations characterized in human induced pluripotent stem cells share $60 \%$ similarity with the oxidative-stress-related CG $>$ AT background mutation pattern [299]. Other components in red meat, such as heme iron, can damage organs by inducing free radical formation, and lipid peroxidation products formed in cooked meat also may form DNA adducts or serve as tumor promoters [286]. Studies on the role of PhIP, other cooked meat genotoxicants and meat-related chemicals in DNA adduct formation, mutational signatures, and DNA 

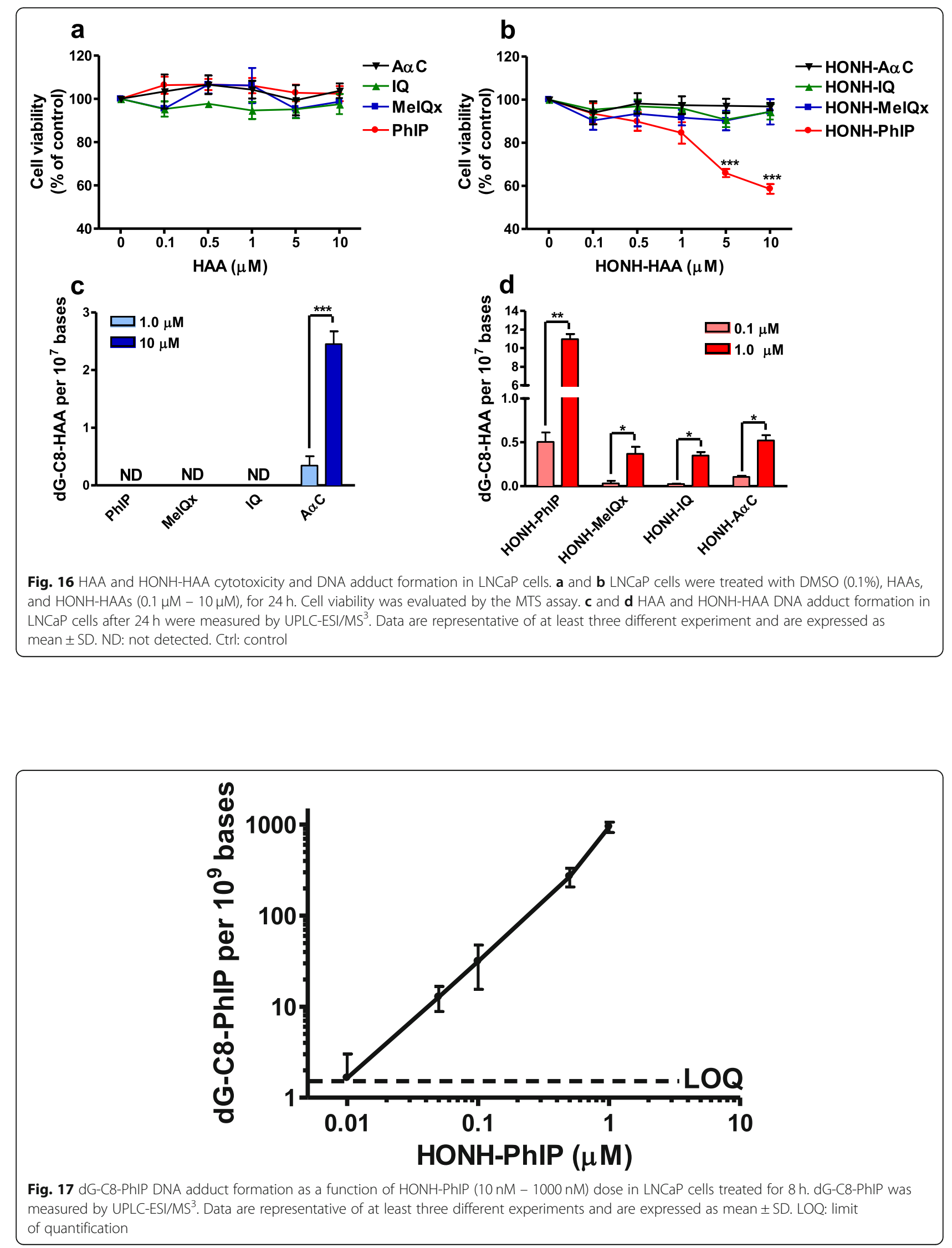
repair in human prostate epithelial cells are warranted to advance the mechanisms by which chemicals in cooked meat contribute to prostate mutagenesis.

In addition to its tumor-initiating activity, PhIP may act via non-genotoxic mechanisms, possibly through the AR, leading to cell proliferation, inflammation, and PC development [90, 97, 98, 300]. Molecular docking simulation showed that PhIP and HONH-PhIP bound to the $\mathrm{AR}$ at comparable affinities to those of the endogenous AR ligand, dihydrotestosterone (DHT), and their binding competes with DHT in the native AR binding cavity of the receptor [300]. Moreover, LNCaP treatment with PhIP or HONH-PhIP resulted in the up-regulation of the expression of both AR and PSA protein, demonstrating that both PhIP compounds activate AR [300]. In addition, PhIP at $\mathrm{nM}$ concentrations also induced proliferation, migration, and invasion in $\mathrm{PC}-3$, an $\mathrm{AR}$ negative human prostate cell line, resulting from the ERK signal transduction cascade [301]. Thus, PhIP may act through androgenic mechanisms and other signal transduction pathways to induce or promote PC at physiologically relevant concentrations.

\section{PhIP metabolomics in prostate cells}

$\mathrm{PhIP}$ induces molecular changes in AR and other proteins involved in $\mathrm{PC}$ in vivo in rodent prostate that can impact the metabolome [90]. We examined the effects of HONH-PhIP $(0,10$, up to $1000 \mathrm{nM})$ on the LNCaP metabolome, [302] employing DHT and tert-butyl hydroperoxide $(t-\mathrm{BuOOH})$ as test compounds for cell proliferation [303] and oxidative stress [304], respectively, since PhIP induces both biological events in the rodent prostate [98]. Statistical clustering of metabolite intensities produced distinct separations between the control and HONH-PhIP, DHT, and $t-\mathrm{BuOOH}$ treated cells indicating changes in the metabolic profiles

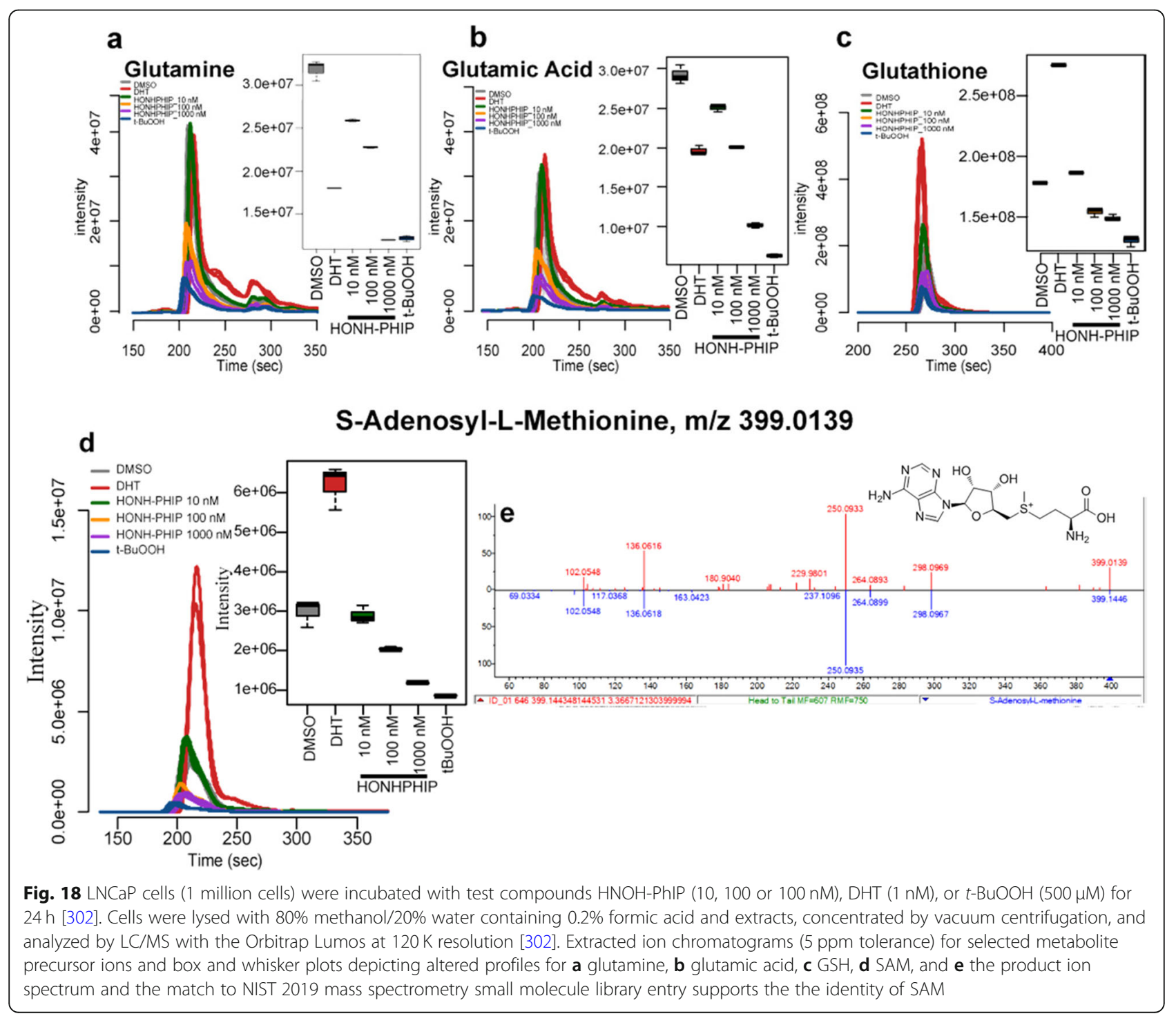


following a 24-h treatment. Decreased glutamate and glutamine levels, intermediates in GSH biosynthesis, and decreased levels of GSH were detected. GSH is the most abundant antioxidant in the cell and the major player in cytoprotection against oxidative stress, whereas amino acid biosynthesis is linked to AR activation [305]. Oxidative stress and AR activation are critical events for PC development [303, 306]. S-Adenosyl-L-methionine (SAM) levels, an intermediate in GSH biosynthesis, and a key methyl donor that modulates DNA methylation and gene expression [307], also decreased in cells treated with $\mathrm{HONH}-\mathrm{PhIP}$ and $t$-BuOOH but increased in DHTtreated cells (Fig. 18). Molecular identification followed by mummichog pathway and network analysis probed the metabolites and metabolic pathways altered by these chemical treatments [308]. The analyses were guided by preselection of significantly altered metabolites (ANOVA and Tukey HSD, $p<0.01$ ), which identified several molecules in 13 metabolic pathways that were significantly up-or down-regulated by HONH-PhIP (Fig. 19). This data implies that HOHN-PhIP can serve as a modulator of gene and protein activity, impacting the metabolome [310]. However, LNCaP cells harbors mutations, including the loss of UGT and GST expression, two Phase II enzymes involved in HAA detoxication [213, 311], and contain multiple deleterious mutations in DNA repair genes, which impact the biological effects of HONHPhIP [312]. Thus, our preliminary studies in LNCaP cells should be interpreted cautiously and may not accurately portray the metabolomic changes, DNA damage, and mutations induced by HONH-PhIP in healthy prostate cells. Mechanistic studies in normal primary prostate epithelial cells are required to advance our knowledge on the role of PhIP and its metabolites in prostate cancer biology.

\section{Conclusions}

More than 20 HAAs form in high-temperature cooked red and processed meats, poultry, fish, and some HAAs arise in combusted tobacco. HAAs are mutagenic in bacterial and mammalian cells, and they induce mutations in oncogenes and tumor suppressor genes of rodents fed HAAs as part of the diet. HAAs induce cancers in the colon, pancreas, breast, and prostate of rodents; these are common cancer sites in Western countries where meat consumption is prevalent. Thus, there is much interest in the potential role of HAAs in meat-associated cancers. The mutational signatures of PhIP show similarity to COSMIC SBS4, SBS18, and SBS29 mutational signatures found in several types of human tumors [65]. However, these signatures are not unique to PhIP, and DNA adducts of other environmental or dietary genotoxicants are also likely to contribute to these mutations. Thus, specific chemical biomarkers of PhIP and other HAAs are required for molecular epidemiology studies investigating the role of cooked meat, HAAs, and cancer risk.

PhIP is the most abundant HAA carcinogen formed in well-done cooked meats. Currently, the PhIP hair biomarker is the only long-term HAA biomarker available and serves as a surrogate for estimating total HAA exposure. Many omnivores harbor PhIP in their hair,

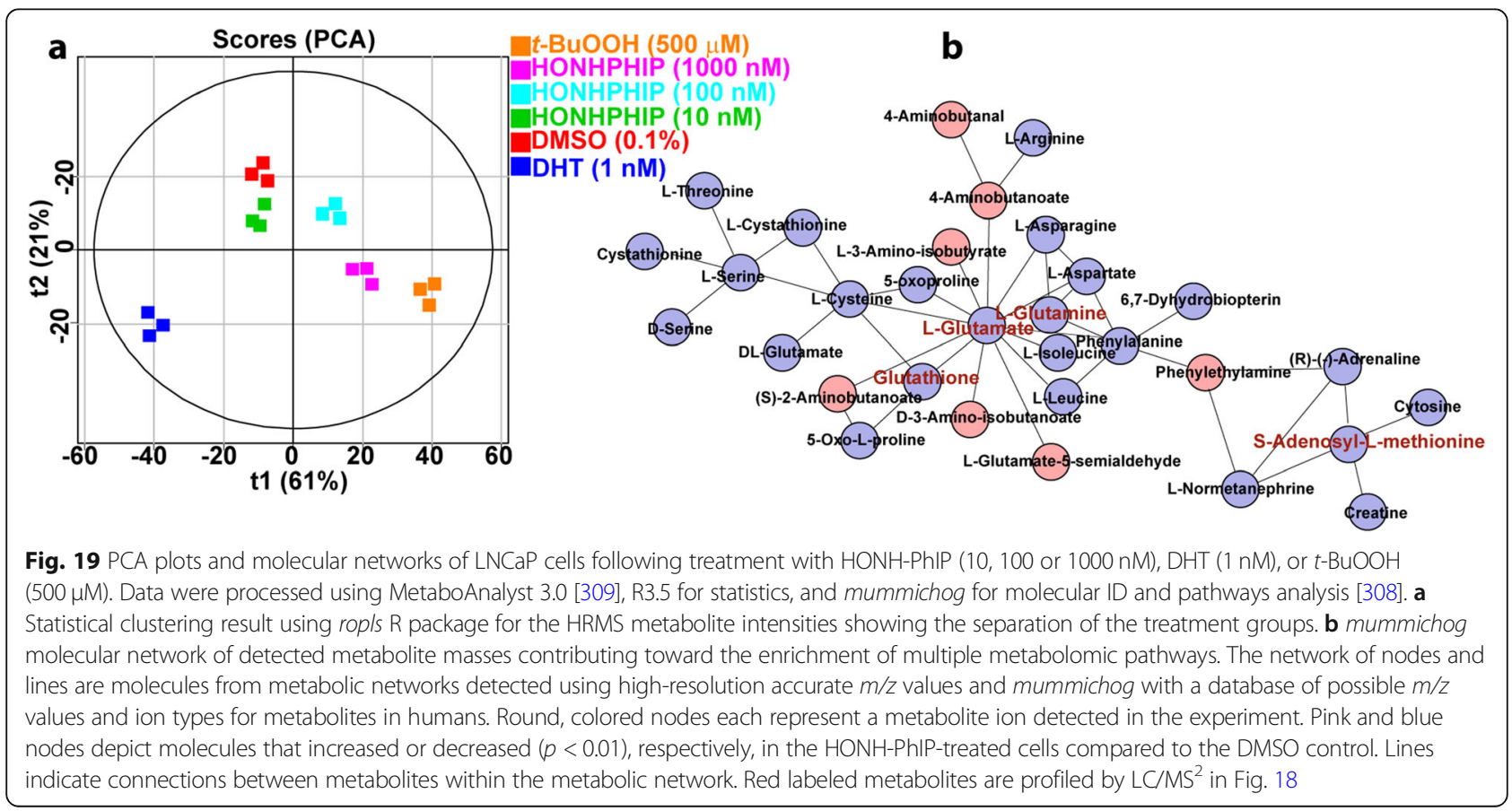


demonstrating that cooked meat consumption is prevalent, and exposure to PhIP (and other HAAs) is widespread. The PhIP hair biomarker proves that PhIP is bioavailable and undergoes systemic circulation. Biomonitoring PhIP in hair is expected to be a more reliable estimate of HAA exposure than the FFQ commonly used in epidemiology studies. However, the PhIP level in hair is a measure of exposure and biomarkers of the biologically effective dose, including HAA-DNA and HAAprotein adducts, should be implemented in epidemiology studies investigating the health risk of HAAs in cooked meats. Further development of PhIP-SA adduct biomarkers is warranted.

The large body of research shows that humans efficiently bioactivate HAAs to reactive intermediates. The major pathway of PhIP metabolism in humans occurs through CYP1A2 mediated $\mathrm{N}$-oxidation to produce the reactive intermediate $\mathrm{HONH}-\mathrm{PhIP}$, which covalently binds to protein and DNA. The primary metabolites of PhIP in the urine of omnivores are Gluc conjugates of HONH-PhIP, demonstrating the critical role of UGT enzymes in PhIP metabolism. PhIP also induces cellular signaling pathways in human prostate cells at human dietary exposure levels, resulting in increased cell proliferation and cell migration, processes linked to the promotion and progression of neoplasia. Thus, PhIP may act as a tumor-initiator and promoter in the prostate and possibly other cancer target organs. Red meat contains a complex group of chemicals. Other chemicals formed during high-temperature cooking may contribute to cancer risk by acting as tumor initiators or promoters or by modulating carcinogen metabolism enzyme expression and activity, impacting the biological effects of HAAs. Future cohort studies implementing HAA biomarkers measured by specific mass spectrometry methods, combined with genetic polymorphisms in genes encoding carcinogen metabolism and DNA repair enzymes, can advance our knowledge on the health risks of dietary HAAs in human cancer.

\footnotetext{
Abbreviations

AMS: Accelerator mass spectrometry; AP: Adenomatous polyposis coli; AIAs: Aminoimidazoarenes; AAs: Aromatic amines; AR: Androgen receptor; CYP: Cytochrome P450; DHT: Dihydrotestosterone; FFQ: Food Frequency Questionnaire; GC-NICI-MS: Gas chromatography with negative ion chemical ionization-mass spectrometry; GST: Glutathione S-transferase; HAAs: Heterocyclic aromatic amines; Hb: Hemoglobin; IHC: Immunohistochemistry; LC/MS: Liquid chromatography/mass spectrometry; met- $\mathrm{Hb}$ : Methemoglobin; $\mathrm{HbO}_{2}$ : Oxy-hemoglobin; PAH: Polycyclic aromatic hydrocarbons; ppb: Parts-per-billion; SA: Serum albumin; SULTs: Sulfotransferases; $t-\mathrm{BuOOH}$ : Tert-butyl hydroperoxide; UGTs: Uridine diphosphate-Glucuronosyltransferases; WGS: Whole-genome sequencing; ANL: Aniline; HONH-ANL: Phenylhdroxylamine; 4-ABP: 4aminobiphenyl; HONH-4-ABP: N-hydroxy-4-aminobiphenyl; IFP: 2-amino-1,6dimethylfuro[3,2-e]imidazo[4,5-b]pyridine; AAF: N-acetyl-2-aminofluorene; $\mathrm{AFB}_{1}$ : Aflatoxin $\mathrm{B}_{1}$; Trp- $\mathrm{P}^{-1}$ : 3-amino-1,4-dimethyl-5H-pyrido[4,3-b]indole; TrpP-2: 3-amino-1-methyl-5H-pyrido[4,3-b]indole; Glu-P-2: 2-aminodiprido[1,2$a, 3^{\prime}, 2^{\prime}$-d] imidazole; Glu-P-1: 2-amino-6-methyldiprido[1,2-a,3',2'-d]imidazole; APNH: 9-(4'-aminophenyl)-9H-pyrido[3,4-b]indole; AMPNH: 9-(4'-amino-3-
}

methylphenyl)-9H-pyrido[3,4-b]indole; IQx: 2-amino-3-methylimidazo[4,5fqquinoxaline; IgQx: 2-amino-3-methylimidazo[4,5-g]quinoxaline; 7-MelgQx: 2amino-3,7-dimethylimidazo[4,5-g]quinoxaline; 7,9-DiMelgQx: 2-amino-3,7,9trimethylimidazo[4,5-g]quinoxaline; MelQx: 2-amino-3,8-dimethylimidazo[4,5f]quinoxaline; HONH-MelQx: N-hydroxy-2-amino-3,8-dimethylimidazo[4,5f]quinoxaline; IQx-8-COOH: 2-amino-3-methylimidazo[4,5-f]quinoxaline-8carboxylic acid; 8- $\mathrm{CH}_{2} \mathrm{OH}-\mathrm{IQx}$ : 2-amino-8-(hydroxymethyl)-3methylimidazo[4,5-f]quinoxaline; MelQx- $N^{2}-G \mid$ : $N^{2}-(B-1-g l u c o s i d u r o n y l)-2-$ amino-3,8-dimethylimidazo[4,5-f]quinoxaline; HON-MelQx- $N^{2}-G l: N^{2}-(B-1-$ glucosiduronyl)-2-(hydroxyamino)-3,8-dimethylimidazo[4,5-f]quinoxaline; MelQx- $N^{2}-\mathrm{SO}_{3} \mathrm{H}: N^{2}$-(3,8-dimethylimidazo[4,5-f]quinoxalin-2-yl-sulfamic acid; DMIP: 2-amino-1,7-dimethylimidazo[4,5-b]pyridine; TMIP: 2-amino-1,5,6trimethylimidazo[4,5-b]pyridine; 4,8-DiMelQx: 2-amino-3,4,8trimethylimidazo[4,5-f]quinoxaline; 7,8-DiMelQx: 2-amino-3,7,8trimethylimidazo[4,5-f quinoxaline; MelQ: 2-amino-3,4-dimethylimidazo[4,5f]quinoline; IQ: 2-amino-3-methylimidazo[4,5-f]quinoline; $\mathrm{HONH}-\mathrm{IQ}: \mathrm{N}$ hydroxy-2-amino-3-methylimidazo[4,5-f quinoline; IQ[4,5-b]: 2-amino-1methylimidazo[4,5-b]quinoline; PhIP: 2-amino-1-methyl-6-phenylimidazo[4,5b]pyridine; HONH-PhIP: N-hydroxy-2-amino-1-methyl-6-phenylimidazo[4,5b]pyridine; HON-PhIP-N²-Gl: $N^{2}$-(ß-1-glucosiduronyl-2-(hydroxyamino)-1methyl-6-phenylimidazo[4,5-b]pyridine; HON-PhIP-N3-Gl: N3-(ß-1glucosiduronyl-2-(hydroxyamino)-1-methyl-6-phenylimidazo[4,5-b]pyridine; PhIP-N²-Gl: $N^{2}$-(ß-1-glucosiduronyl-2-amino-1-methyl-6-phenylimidazo[4,5b]pyridine; PhIP-N3-Gl: N3-(ß-1-glucosiduronyl-2-amino-1-methyl-6phenylimidazo[4,5-b]pyridine; MeAaC: 2-amino-3-methyl-9H-pyrido[2,3b]indole; AaC: 2-amino-9H-pyrido[2,3-b]indole; HONH-AaC: 2-hydroxyamino9H-pyrido[2,3-b]indole; dG-C8-APNH: N4'-(2'-deoxyguanosin-8-yl)-4aminophenylnorharman; dG-C8-MelQx: N-(2'-deoxyguanosin-8-yl)-MelQx; dGC8-4,8-DiMelQx: N-(2'-deoxyguanosin-8-yl)-4,8-MelQx; dG-N²-MelQx: 5-(2'deoxyguanosin- $N^{2}$-yl)-MelQx; dG-C8-IQ: N-(2'-deoxyguanosin-8-yl)-IQ; dA-N $N^{6}$ IQ: 5-(2'-deoxyadenosin- $\left.N^{6}-y \mid\right)-\mid Q ; d G-N^{2}-I Q$ : 5-(2'-deoxyguanosin- $\left.N^{2}-y \mid\right)-I Q ; d G-$ N7-IQ: N-(2'-deoxyguanosin-7-yl)-IQ; dG-C8-MelQ: N-(2'-deoxyguanosin-8-yl)MelQ; dG-C8-AaC: N-(deoxyguanosin-8-yl)-AaC; dG-C8-MeAaC: N-(2'deoxyguanosin-8-yl)-MeAaC; dG-C8-PhIP: N-(2'-deoxyguanosin-8-yl)-PhIP; 8oxo-dG: 8-oxo-2'-deoxyguanosine

\section{Acknowledgments}

This manuscript is dedicated to the memory of Dr. Takashi Sugimura, whose body of work on food mutagens has been an inspiration to the Turesky Laboratory for over 30 years. The Turesky Laboratory gratefully acknowledges the support of the Masonic Chair in Cancer Causation.

\section{Conflict of interest}

The authors have no conflict of interest to declare.

\section{Authors' contributions}

$M B, S J W$, and RJT contributed to drafting this manuscript review. RJT obtained funding to support HAA research. The author(s) read and approved the final manuscript.

Funding

R01CA122320 and the National Cancer Institute Cancer Center Support Grant CA077598 supported a portion of the research conducted in the Turesky Laboratory.

Availability of data and materials

All generated data are included in this manuscript, or were obtained from peer-reviewed articles cited in the literature.

\section{Declarations}

Ethics approval and consent to participate

Not applicable.

\section{Consent for publication}

Not applicable.

Competing interests

The authors declare that they have no competing interests. 


\section{Author details}

'Masonic Cancer Center and Department of Medicinal Chemistry, Cancer and Cardiovascular Research Building, University of Minnesota, 2231 6th Street, Minneapolis, MN 55455, USA. ${ }^{2}$ Department of Medicinal Chemistry, College of Pharmacy, University of Minnesota, Minneapolis, MN 55455, USA. ${ }^{3}$ Institute of Health Informatics, University of Minnesota, Minneapolis, MN 55455, USA.

Received: 5 May 2021 Accepted: 27 June 2021

Published online: 16 July 2021

\section{References}

1. Sugimura T, Nagao N, Kawachi T, Honda M, Yahagi T, Seino Y, et al. Mutagen-carcinogens in food, with special reference to highly mutagenic pyrolytic products in broiled foods. Cold Spring Harbor: Hiatt HH, Watson JD, Winstein JA, Cold Spring Harbor Laboratory; 1977. p. 1561-77.

2. Sugimura T, Wakabayashi K, Nakagama H, Nagao M. Heterocyclic amines: mutagens/carcinogens produced during cooking of meat and fish. Cancer Sci. 2004;95:290-9.

3. Skog K, Augustsson K, Steineck G, Stenberg M, Jagerstad M. Polar and nonpolar heterocyclic amines in cooked fish and meat products and their corresponding pan residues. Food Chem Toxicol. 1997;35:555-65.

4. Wakabayashi K, Kim IS, Kurosaka R, Yamaizumi Z, Ushiyama H, Takahashi M, et al. Identification of new mutagenic heterocyclic amines and quantification of known heterocyclic amines. Princeton: Adamson $\mathrm{RH}$, Gustafson DR, Ito N, Nagao M, Sugimura T, Wakabayashi K, Yamazoe Y, Princeton Scientific Publishing Co., Inc; 1995. p. 39-49.

5. Wakabayashi K, Nagao M, Esumi $H$, Sugimura T. Food-derived mutagens and carcinogens. Cancer Res. 1992;52:2092s-8s.

6. Felton JS, Jagerstad M, Knize MG, Skog K, Wakabayashi K. Contents in foods, beverages and tobacco. Chichester: Nagao M, Sugimura T, John Wiley \& Sons Ltd; 2000. p. 31-71.

7. Felton JS, Knize MG, Shen NH, Andresen BD, Bjeldanes LF, Hatch FT. Identification of the mutagens in cooked beef. Environ Health Perspect. 1986:67:17-24.

8. Alaejos MS, Gonzalez V, Afonso AM. Exposure to heterocyclic aromatic amines from the consumption of cooked red meat and its effect on human cancer risk: a review. Food Addit Contam Part A Chem Anal Control Expo Risk Assess. 2008;25:2-24.

9. Ohgaki H, Hasegawa H, Kato T, Suenaga M, Ubukata M, Sato S, et al. Carcinogenicity in mice and rats of heterocyclic amines in cooked foods. Environ Health Perspect. 1986;67:129-34.

10. Ohgaki H, Takayama S, Sugimura T. Carcinogenicities of heterocyclic amines in cooked food. Mutat Res. 1991;259:399-410.

11. Sugimura T. Multistep carcinogenesis: a 1992 perspective. Science. 1992;258: 603-7.

12. Ito N, Hasegawa R, Sano M, Tamano S, Esumi H, Takayma S, et al. A new colon and mammary carcinogen in cooked food, 2-amino-1-methyl-6phenylimidazo[4,5-b]pyridine (PhIP). Carcinogenesis. 1991;12:1503-6.

13. Shirai T, Sano M, Tamano S, Takahashi S, Hirose M, Futakuchi M, et al. The prostate: a target for carcinogenicity of 2-amino-1-methyl-6phenylimidazo[4,5-b]pyridine (PhIP) derived from cooked foods. Cancer Res. 1997;57:195-8.

14. Sugimura T. Mutagens, carcinogens, and tumor promoters in our daily food. Cancer. 1982:49:1970-84.

15. Sugimura T, Sato S. Mutagens-carcinogens in foods. Cancer Res. 1983;43: 2415s-21s.

16. Sugimura T. Past, present, and future of mutagens in cooked foods. Environ Health Perspect. 1986:67:5-10.

17. Sugimura T. Nutrition and dietary carcinogens. Carcinogenesis. 2000;21 387-95.

18. Ames BN, McCann J, Yamasaki E. Methods for detecting carcinogens and mutagens with the Salmonella/mammalian-microsome mutagenicity test. Mutat Res. 1975;31:347-64.

19. Sugimura T. Successful use of short-term tests for academic purposes: their use in identification of new environmental carcinogens with possible risk for humans. Mutat Res. 1988;205:33-9.

20. Yamamoto T, Tsuji K, Kosuge T, Okamoto T, Shudo K, Takeda K, et al. Isolation and structure determination of mutagenic substances in $\mathrm{L}$ glutamic acid pyrolysate. Proc Jpn Acad Ser B. 1978;54:248-50.
21. Yoshida D, Matsumoto T, Yoshimura R, Matsuzaki T. Mutagenicity of aminoa-carbolines in pyrolysis products of soybean globulin. Biochem BiophysRes Commun. 1978:83:915-20.

22. Matsumoto T, Yoshida D, Tomita H. Determination of mutagens, amino-acarbolines in grilled foods and cigarette smoke condensate. Cancer Lett. 1981:12:105-10.

23. Yoshida D, Matsumoto T. Amino-a-carbolines as mutagenic agents in cigarette smoke condensate. Cancer Lett. 1980;10:141-9.

24. Yamaizumi Z, Shiomi T, Kasai H, Nishimura S, Takahashi Y, Nagao M, et al. Detection of potent mutagens, Trp-P-1 and Trp-P-2, in broiled fish. Cancer Lett. 1980;9:75-83.

25. Ni W, McNaughton L, LeMaster DM, Sinha R, Turesky RJ. Quantitation of 13 heterocyclic aromatic amines in cooked beef, pork, and chicken by liquid chromatography-electrospray ionization/tandem mass spectrometry. J Agric Food Chem. 2008;56:68-78.

26. Yoshida D, Matsumoto T. Amino-alpha-carbolines as mutagenic agents in cigarette smoke condensate. Cancer Lett. 1980;10:141-9.

27. Kasai H, Nishimura S, Nagao M, Takahashi Y, Sugimura T. Fractionation of a mutagenic principle from broiled fish by high-pressure liquid chromatography. Cancer Lett. 1979;7:343-8.

28. Spingarn NE, Kasai H, Vuolo LL, Nishimura S, Yamaizumi Z, Sugimura T, et al. Formation of mutagens in cooked foods. III. Isolation of a potent mutagen from beef. Cancer Lett. 1980;9:177-83.

29. Kasai H, Yamaizumi K, Wakabayashi K, Nagao M, Sugimura T, Yokoyama T, et al. Structure and chemical synthesis of Me-IQ, a potent mutagen isolated from broiled fish. Chem Lett. 1980;9:1391-4.

30. Kasai H, Yamazumi Z, Shiomi T, Yokoyama S, Miyazawa T, Wakabayashi K, et al. Structure of a potent mutagen isolated from fried beef. Chem Lett. 1981:485-8.

31. Felton JS, Knize MG, Shen NH, Lewis PR, Andresen BD, Happe J, et al. The isolation and identification of a new mutagen from fried ground beef: 2amino-1-methyl-6-phenylimidazo[4,5-b]pyridine (PhIP). Carcinogenesis. 1986; 7:1081-6.

32. Skog Kl, Johansson MA, Jagerstad MI. Carcinogenic heterocyclic amines in model systems and cooked foods: a review on formation, occurrence and intake. Food Chem Toxicol. 1998;36:879-96.

33. Skog K, Steineck G, Augustsson K, Jagerstad M. Effect of cooking temperature on the formation of heterocyclic amines in fried meat products and pan residues. Carcinogenesis. 1995;16:861-7.

34. Knize MG, Dolbeare FA, Carroll KL, Moore DH, Felton JS. Effect of cooking time and temperature on the heterocyclic amine content of fried beef patties. Food Chem Toxicol. 1994;32:595-603.

35. Sinha R, Rothman N, Brown ED, Salmon CP, Knize MG, Swanson CS, et al. High concentrations of the carcinogen 2-amino-1-methyl-6phenylimidazo[4,5-b]pyridine (PhIP) occur in chicken but are dependent on the cooking method. Cancer Res. 1995;55:4516-9.

36. Yan Y, You FH, Zeng MM, Chen J, Huang JJ, Jiang J. Evaluating the effects of temperature and time on heterocyclic aromatic amine profiles in roasted pork using combined UHPLC-MS/MS and multivariate analysis. Food Res Int 2021;141:110134.

37. Gross GA, Turesky RJ, Fay LB, Stillwell WG, Skipper PL, Tannenbaum SR. Heterocyclic aromatic amine formation in grilled bacon, beef and fish and in grill scrapings. Carcinogenesis. 1993;14:2313-8.

38. Alaejos MS, Afonso AM. Factors that affect the content of heterocyclic aromatic amines in foods. Compr Rev Food Sci Food Saf. 2011;10:52-108.

39. Nukaya H, Koyota S, Jinno F, Ishida H, Wakabayashi K, Kurosaka R, et al. Structural determination of a new mutagenic heterocyclic amine, 2-amino1,7,9-trimethylimidazo[4,5-g]quinoxaline (7,9-DiMelgQx), present in beef extract. Carcinogenesis. 1994;15:1151-4.

40. Turesky RJ, Goodenough AK, Ni W, McNaughton L, LeMaster DM, Holland $\mathrm{RD}$, et al. Identification of 2-amino-1,7-dimethylimidazo[4,5-g]quinoxaline: an abundant mutagenic heterocyclic aromatic amine formed in cooked beef. Chem Res Toxicol. 2007;20:520-30.

41. Jagerstad M, Skog K, Grivas S, Olsson K. Formation of heterocyclic amines using model systems. Mutat Res. 1991;259:219-33.

42. Murkovic M. Formation of heterocyclic aromatic amines in model systems. J Chromatogr B. 2004;802:3-10.

43. Hidalgo FJ, Lavado-Tena CM, Zamora R. Identification of acrolein as the reactive carbonyl responsible for the formation of 2-amino-3,8dimethylimidazo[4,5-f]quinoxaline (MelQx). Food Chem. 2021;343:128478. 
44. Totsuka Y, Wakabayashi K. Biological significance of aminophenyl-betacarboline derivatives formed from co-mutagenic action of beta-carbolines and aniline and o-toluidine and its effect on tumorigenesis in humans: a review. Mutat Res. 2020;850-851.

45. Nishigaki R, Totsuka Y, Kataoka H, Ushiyama H, Goto S, Akasu T, et al. Detection of aminophenylnorharman, a possible endogenous mutagenic and carcinogenic compound, in human urine samples. Cancer Epidemiol Biomark Prev. 2007:16:151-6.

46. Holland RD, Gehring T, Taylor J, Lake BG, Gooderham NJ, Turesky RJ. Formation of a mutagenic heterocyclic aromatic amine from creatinine in urine of meat eaters and vegetarians. Chem Res Toxicol. 2005;18:579-90.

47. Felton JS, Knize MG. Occurrence, identification, and bacterial mutagenicity of heterocyclic amines in cooked food. Mutat Res. 1991;259:205-17.

48. Fuscoe JC, Wu R, Shen NH, Healy SK, Felton JS. Base-change analysis of revertants of the hisD3052 allele in Salmonella typhimurium. Mutat Res. 1988;201:241-51.

49. Turesky RJ, Le Marchand L. Metabolism and biomarkers of heterocyclic aromatic amines in molecular epidemiology studies: lessons learned from aromatic amines. Chem Res Toxicol. 2011;24:1169-214.

50. McCoy EC, Anders M, Rosenkranz HS. The basis of the insensitivity of Salmonella typhimurium strain TA98/1,8-DNP 6 to the mutagenic action of nitroarenes. Mutat Res. 1983;121:17-23.

51. Watanabe M, Ishidate M Jr, Nohmi T. Sensitive method for the detection of mutagenic nitroarenes and aromatic amines: new derivatives of Salmonella typhimurium tester strains possessing elevated O-acetyltransferase levels. Mutat Res. 1990:234:337-48.

52. Kosakarn P, Halliday JA, Glickman BW, Josephy PD. Mutational specificity of 2-nitro-3,4-dimethylimidazo[4,5-f]quinoline in the lacl gene of Escherichia coli. Carcinogenesis. 1993;14:511-7.

53. Watanabe M, Ohta T. Analysis of mutational specificity induced by heterocyclic amines in the lacZ gene of Escherichia coli. Carcinogenesis. 1993;14:1149-53.

54. Solomon MS, Leong Morgenthaler PM, Turesky RJ, Essigmann JM. Mutational and DNA binding specificity of the carcinogen 2-amino-3,8dimethylimidazo[4,5-f]quinoxaline. J Biol Chem. 1996;271:18368-74.

55. Thompson LH, Tucker JD, Stewart SA, Christensen ML, Salazar EP, Carrano AV, et al. Genotoxicity of compounds from cooked beef in repair-deficient CHO cells versus Salmonella mutagenicity. Mutagenesis. 1987;2:483-7.

56. Nakayasu M, Nakasato F, Sakamoto H, Terada M, Sugimura T. Mutagenic activity of heterocyclic amines in Chinese hamster lung cells with diphtheria toxin resistance as a marker. Mutat Res. 1983;118:91-102.

57. Thompson LH, Carrano AV, Salazar E, Felton JS, Hatch FT. Comparative genotoxic effects of the cooked-food-related mutagens Trp-P- 2 and IQ in bacteria and cultured mammalian cells. Mutat Res. 1983;117:243-57.

58. Morgenthaler PM, Holzhauser D. Analysis of mutations induced by 2-amino1-methyl-6-phenylimidazo[4,5-b]pyridine (PhIP) in human lymphoblastoid cells. Carcinogenesis. 1995;16:713-8.

59. Carothers AM, Yuan W, Hingerty BE, Broyde S, Grunberger D, Snyderwine EG. Mutation and repair induced by the carcinogen 2 (hydroxyamino)-1-methyl-6-phenylimidazo[4,5-b]pyridine (N-OH-PhIP) in the dihydrofolate reductase gene of Chinese hamster ovary cells and conformational modeling of the dG-C8-PhIP adduct in DNA. Chem Res Toxicol. 1994;7:209-18.

60. Wu RW, Wu EM, Thompson LH, Felton JS. Identification of aprt gene mutations induced in repair-deficient and P450-expressing $\mathrm{CHO}$ cells by the food-related mutagen/carcinogen, PhIP. Carcinogenesis. 1995;16:1207-13.

61. Yadollahi-Farsani M, Gooderham NJ, Davies DS, Boobis AR. Mutational spectra of the dietary carcinogen 2-amino-1-methyl-6-phenylimidazo[4,5-b]pyridine (PhIP) at the Chinese hamsters hprt locus. Carcinogenesis. 1996;17:617-24.

62. Kakiuchi $H$, Watanabe $M$, Ushijima T, Toyota M, Imai K, Weisburger JH, et al. Specific $5^{\prime}$-GGGA-3' --> 5'-GGA-3' mutation of the APC gene in rat colon tumors induced by 2-amino-1-methyl-6-phenylimidazo[4,5-b]pyridine. ProcNat|AcadSciUSA. 1995;92:910-4.

63. Schut HA, Snyderwine EG. DNA adducts of heterocyclic amine food mutagens: implications for mutagenesis and carcinogenesis. Carcinogenesis. 1999:20:353-68.

64. Kato R, Yamazoe Y. Metabolic activation and covalent binding to nucleic acids of carcinogenic heterocyclic amines from cooked foods and amino acid pyrolysates. Jpn J Cancer Res. 1987;78:297-311.

65. Holzl-Armstrong L, Moody S, Kucab JE, Zwart EP, Bellamri M, Luijten M, et al. Mutagenicity of 2-hydroxyamino-1-methyl-6-phenylimidazo[4,5-b]pyridine
(N-OH-PhIP) in human TP53 knock-in (Hupki) mouse embryo fibroblasts. Food Chem Toxicol. 2021;147:111855.

66. Nagao N, Wakabayashi K, Ushijima U, Toyota M, Totsuka Y, Sugimura T. Human exposure to carcinogenic heterocyclic amines and their mutational fingerprints in animals. Environ Health Perspect. 1996;104(Supplement 3): 497-501.

67. Nagao M, Ushijima T, Toyota M, Inoue R, Sugimura T. Genetic changes induced by heterocyclic amines. Mutat Res. 1997;376:161-7.

68. Nagao M, Sugimura T. Carcinogenic factors in food with relevance to colon cancer development. Mutat Res. 1993;290:43-51.

69. Fodde R. The APC gene in colorectal cancer. Eur J Cancer. 2002;38:867-71.

70. Burnouf D, Miturski R, Nagao M, Nakagama H, Nothisen M, Wagner J, et al. Early detection of 2-amino-1-methyl-6-phenylimidazo[4,5-b]pyridine (PhIP)induced mutations within the Apc gene of rat colon. Carcinogenesis. 2001; 22:329-35.

71. Okonogi H, Stuart GR, Okochi E, Ushijima T, Sugimura T, Glickman BW, et al. Effects of gender and species on spectra of mutation induced by 2-amino1-methyl-6-phenylimidazo[4,5-b]pyridine in the lacl transgene. Mutat Res. 1997;395:93-9.

72. Okonogi H, Ushijima T, Zhang XB, Heddle JA, Suzuki T, Sofuni T, et al. Agreement of mutational characteristics of heterocyclic amines in lacl of the big blue mouse with those in tumor related genes in rodents. Carcinogenesis. 1997:18:745-8.

73. Okochi E, Watanabe N, Shimada Y, Takahashi S, Wakazono K, Shirai T, et al Preferential induction of guanine deletion at $5^{\prime}-\mathrm{GGGA}-3^{\prime}$ in rat mammary glands by 2-amino-1-methyl-6-phenylimidazo[4,5-b]pyridine. Carcinogenesis. 1999:20:1933-8.

74. Stuart GR, Holcroft J, de Boer JG, Glickman BW. Prostate mutations in rats induced by the suspected human carcinogen 2-amino-1-methyl-6phenylimidazo[4,5-b]pyridine. Cancer Res. 2000;60:266-8.

75. Dashwood RH, Suzui M, Nakagama H, Sugimura T, Nagao M. High frequency of beta-catenin ( ctnnb1) mutations in the colon tumors induced by two heterocyclic amines in the F344 rat. Cancer Res. 1998;58:1127-9.

76. Ushijima T, Kakiuchi H, Makino H, Hasegawa R, Ishizaka Y, Hirai H, et al. Infrequent mutation of Ha-ras and p 53 in rat mammary carcinomas induced by 2-amino-1-methyl-6-phenylimidazo[4,5-b]pyridine. Mol Carcinog. 1994;10:38-44

77. Makino $H$, Ushijima $T$, Kakiuchi $H$, Onda $M$, Ito $N$, Sugimura $T$, et al. Absence of p53 mutations in rat colon tumors induced by 2-amino-6-methyldipyrido [1,2-a:3',2'-d] imidazole, 2-amino-3-methylimidazo[4,5-f]quinoline, or 2amino-1-methyl-6-phenylimidazo[4,5-b]pyridine. Jpn J Cancer Res Gann. 1994:85:510-4.

78. Kudo M, Ogura T, Esumi H, Sugimura T. Mutational activation of c-Ha-ras gene in squamous cell carcinomas of rat Zymbal gland induced by carcinogenic heterocyclic amines. Mol Carcinog. 1991;4:36-42.

79. Ushijima T, Makino H, Kakiuchi H, Inoue R, Sugimura T, Nagao M. Genetic alterations in HCA-induced tumors. Princess Takamatsu Symp. 1995;23:281-91.

80. Tachino N, Hayashi R, Liew C, Bailey G, Dashwood R. Evidence for ras gene mutation in 2-amino-3-methylimidazo[4,5-f]quinoline-induced colonic aberrant crypts in the rat. Mol Carcinog. 1995;12:187-92.

81. Fujimoto Y, Hampton LL, Snyderwine EG, Nagao M, Sugimura T, Adamson $\mathrm{RH}$, et al. p53 gene mutation in hepatocellular carcinoma induced by $2-$ amino-3-methylimidazo[4,5-f]quinoline in nonhuman primates. Jpn J Cancer Res. 1994;85:506-9.

82. Sugimura T. Overview of carcinogenic heterocyclic amines. Mutat Res. 1997;376: 211-9.

83. Archer $\mathrm{CL}$, Morse $\mathrm{P}$, Jones RF, Shirai $\mathrm{T}$, Haas GP, Wang CY. Carcinogenicity of the $\mathrm{N}$-hydroxy derivative of 2-amino-1-methyl-6-phenylimidazo[4,5b]pyridine, 2-amino-3, 8-dimethyl-imidazo[4,5-f]quinoxaline and 3, 2'dimethyl-4-aminobiphenyl in the rat. Cancer Lett. 2000;155:55-60.

84. Le Marchand L, Hankin JH, Pierce LM, Sinha R, Nerurkar PV, Franke AA, et al. Well-done red meat, metabolic phenotypes and colorectal cancer in Hawaii. Mutat Res. 2002;506-507:205-14.

85. Sinha R, Kulldorff M, Chow WH, Denobile J, Rothman N. Dietary intake of heterocyclic amines, meat-derived mutagenic activity, and risk of colorectal adenomas. Cancer Epidemiol Biomark Prev. 2001;10:559-62.

86. Sinha R, Rothman N. Role of well-done, grilled red meat, heterocyclic amines (HCAs) in the etiology of human cancer. Cancer Lett. 1999;143:189-94.

87. Bouvard V, Loomis D, Guyton KZ, Grosse Y, Ghissassi FE, Benbrahim-Tallaa L, et al. Carcinogenicity of consumption of red and processed meat. Lancet Oncol. 2015;16:1599-600. 
88. Zheng W, Lee SA. Well-done meat intake, heterocyclic amine exposure, and cancer risk. Nutr Cancer. 2009;61:437-46.

89. Punnen S, Hardin J, Cheng I, Klein EA, Witte JS. Impact of meat consumption, preparation, and mutagens on aggressive prostate cancer. PLoS One. 2011;6:e27711.

90. Li G, Wang H, Liu AB, Cheung C, Reuhl KR, Bosland MC, et al. Dietary carcinogen 2-amino-1-methyl-6-phenylimidazo[4,5-b]pyridine-induced prostate carcinogenesis in CYP1A-humanized mice. Cancer Prev Res (Phila). 2012;5:963-72.

91. Takayama S, Thorgeirsson UP, Adamson RH. Chemical carcinogenesis studies in nonhuman primates. Proc Jpn Acad Ser B Phys Biol Sci. 2008;84: 176-88.

92. Snyderwine EG, Turesky RJ, Turteltaub KW, Davis CD, Sadrieh N, Schut HA, et al. Metabolism of food-derived heterocyclic amines in nonhuman primates. Mutat Res. 1997;376:203-10.

93. Edwards RJ, Murray BP, Murray S, Schulz T, Neubert D, Gant TW, et al. Contribution of CYP1A1 and CYP1A2 to the activation of heterocyclic amines in monkeys and humans. Carcinogenesis. 1994;15:829-36.

94. Kim JK, McCormick MA, Gallaher CM, Gallaher DD, Trudo SP. Apiaceous vegetables and cruciferous phytochemicals reduced PhIP-DNA adducts in prostate but not in pancreas of Wistar rats. J Med Food. 2018;21:199-202.

95. Dingley KH, Ubick EA, Chiarappa-Zucca ML, Nowell S, Abel S, Ebeler SE, et al. Effect of dietary constituents with chemopreventive potential on adduct formation of a low dose of the heterocyclic amines PhIP and IQ and phase II hepatic enzymes. Nutr Cancer. 2003;46:212-21.

96. Nakai Y, Nelson WG, De Marzo AM. The dietary charred meat carcinogen 2amino-1-methyl-6-phenylimidazo[4,5-b]pyridine acts as both a tumor initiator and promoter in the rat ventral prostate. Cancer Res. 2007;67:1378-84.

97. Nakai Y, Nonomura N. Inflammation and prostate carcinogenesis. Int J Urol. 2013;20:150-60

98. Chen JX, Li G, Wang H, Liu A, Lee MJ, Reuhl K, et al. Dietary tocopherols inhibit PhIP-induced prostate carcinogenesis in CYP1A-humanized mice. Cancer Lett. 2016:371:71-8.

99. Borowsky AD, Dingley KH, Ubick E, Turteltaub KW, Cardiff RD, Devere-White R. Inflammation and atrophy precede prostatic neoplasia in a PhIP-induced rat model. Neoplasia. 2006:8:708-15.

100. Richmond PJ, Karayiannakis AJ, Nagafuchi A, Kaisary AV, Pignatelli M. Aberrant E-cadherin and alpha-catenin expression in prostate cancer: correlation with patient survival. Cancer Res. 1997;57:3189-93.

101. Signoretti S, Waltregny D, Dilks J, Isaac B, Lin D, Garraway L, et al. p63 is a prostate basal cell marker and is required for prostate development. Am J Pathol. 2000;157:1769-75.

102. Di Cristofano A, Pandolfi PP. The multiple roles of PTEN in tumor suppression. Cell. 2000;100:387-90.

103. Kim TJ, Lee YH, Koo KC. Current status and future perspectives of androgen receptor inhibition therapy for prostate cancer: a comprehensive review. Biomolecules. 2021;11.

104. Yamazoe Y, Abu-Zeid M, Manabe S, Toyama S, Kato R. Metabolic activation of a protein pyrolysate promutagen 2-amino-3,8-dimethylimidazo [4,5-f] quinoxaline by rat liver microsomes and purified cytochrome P-450. Carcinogenesis. 1988;9:105-9.

105. Boobis AR, Lynch AM, Murray S, de la Torre R, Solans A, Farr M, et al. CYP1A2-catalyzed conversion of dietary heterocyclic amines to their proximate carcinogens is their major route of metabolism in humans. Cancer Res. 1994:54:89-94

106. Crofts FG, Sutter TR, Strickland PT. Metabolism of 2-amino-1-methyl-6phenylimidazo[4,5-b]pyridine by human cytochrome P4501A1, P4501A2 and P4501B1. Carcinogenesis. 1998;19:1969-73.

107. Turesky RJ, Constable A, Richoz J, Varga N, Markovic J, Martin MV, et al. Activation of heterocyclic aromatic amines by rat and human liver microsomes and by purified rat and human cytochrome P450 1A2. Chem Res Toxicol. 1998;11:925-36.

108. Butler MA, Iwasaki M, Guengerich FP, Kadlubar FF. Human cytochrome P450 PA (P450IA2), the phenacetin $O$-deethylase, is primarily responsible for the hepatic 3-demethylation of caffeine and $\mathrm{N}$-oxidation of carcinogenic arylamines. Proc Natl Acad Sci U S A. 1989:86:7696-700.

109. Langouët S, Welti DH, Kerriguy N, Fay LB, Huynh-Ba T, Markovic J, et al. Metabolism of 2-amino-3,8-dimethylimidazo[4,5-f]quinoxaline in human hepatocytes: 2-amino-3-methylimidazo[4,5-f]quinoxaline-8-carboxylic acid is a major detoxification pathway catalyzed by cytochrome P450 1A2. Chem Res Toxicol. 2001;14:211-21.
110. Wallin H, Mikalsen A, Guengerich FP, Ingelman-Sundberg I, Solberg KE, Rossland OJ, et al. Differential rates of metabolic activation and detoxification of the food mutagen 2-amino-1-methyl-6-phenylimidazo[4,5b]pyridine by different cytochrome P450 enzymes. Carcinogenesis. 1990;11: 489-92.

111. Lin DX, Lang NP, Kadlubar FF. Species differences in the biotransformation of the food-borne carcinogen 2-amino-1-methyl-6-phenylimidazo[4,5b]pyridine by hepatic microsomes and cytosols from humans, rats, and mice. Drug Metab Dispos. 1995;23:518-24.

112. Kimura S, Kawabe M, Ward JM, Morishima H, Kadlubar FF, Hammons GJ, et al. CYP1A2 is not the primary enzyme responsible for 4-aminobiphenylinduced hepatocarcinogenesis in mice. Carcinogenesis. 1999;20:1825-30.

113. Turesky RJ, Konorev D, Fan X, Tang Y, Yao L, Ding X, et al. Effect of cytochrome $\mathrm{P} 450$ reductase deficiency on 2-amino-9H-pyrido [2,3-b] indole metabolism and DNA adduct formation in liver and extrahepatic tissues of mice. Chem Res Toxicol. 2015;28:2400-10.

114. Adamson RH. Carcinogenicity in animals and specific organs. West Sussex: Nagao M, Sugimura T, John Wiley \& Sons Ltd; 2000. p. 229-40.

115. Adamson RH, Thorgeirsson UP, Snyderwine EG, Thorgeirsson SS, Reeves J, Dalgard DW, et al. Carcinogenicity of 2-amino-3-methylimidazo[4,5flquinoline in nonhuman primates: induction of tumors in three macaques. Jpn J Cancer Res. 1990;81:10-4.

116. Belloc C, Baird S, Cosme J, Lecoeur S, Gautier JC, Challine D, et al. Human cytochrome P450 expressed in Escherichia coli: production of specific antibodies. Toxicology. 1996;106:207-19.

117. Turesky RJ, Constable A, Fay LB, Guengerich FP. Interspecies differences in metabolism of heterocyclic aromatic amines by rat and human P450 1A2. Cancer Lett. 1999:143:109-12.

118. Turesky RJ, Parisod V, Huynh-Ba T, Langouët S, Guengerich FP. Regioselective differences in C (8)- and N-oxidation of 2-amino-3,8dimethylimidazo[4,5-f]quinoxaline by human and rat liver microsomes and cytochromes P450 1A2. Chem Res Toxicol. 2001;14:901-11.

119. Turesky RJ, Garner RC, Welti DH, Richoz J, Leveson SH, Dingley KH, et al. Metabolism of the food-borne mutagen 2-amino-3,8-dimethylimidazo[4,5flquinoxaline in humans. Chem Res Toxicol. 1998;11:217-25.

120. Gu D, McNaughton L, LeMaster D, Lake BG, Gooderham NJ, Kadlubar FF, et al. A comprehensive approach to the profiling of the cooked meat carcinogens 2-amino-3,8-dimethylimidazo[4,5-f]quinoxaline, 2-amino-1methyl-6-phenylimidazo[4,5-b]pyridine, and their metabolites in human urine. Chem Res Toxicol. 2010;23:788-801.

121. Gu D, Raymundo MM, Kadlubar FF, Turesky RJ. Ultraperformance liquid chromatography-tandem mass spectrometry method for biomonitoring cooked meat carcinogens and their metabolites in human urine. Anal Chem. 2011;83:1093-101.

122. Malfatti MA, Kuhn EA, Turteltaub KW, Vickers SM, Jensen EH, Strayer $L$, et al. Disposition of the dietary mutagen 2-amino-3,8-dimethylimidazo [4,5-f] quinoxaline in healthy and pancreatic cancer compromised humans. Chem Res Toxicol. 2016;29:352-8.

123. Guengerich FP, Parikh A, Turesky RJ, Josephy PD. Inter-individual differences in the metabolism of environmental toxicants: cytochrome P450 1A2 as a prototype. Mutat Res. 1999:428:115-24.

124. Hein DW, Doll MA, Fretland AJ, Leff MA, Webb SJ, Xiao GH, et al. Molecular genetics and epidemiology of the NAT1 and NAT2 acetylation polymorphisms. Cancer Epidemiol Biomark Prev. 2000;9:29-42.

125. Hein DW. N-Acetyltransferase genetics and their role in predisposition to aromatic and heterocyclic amine-induced carcinogenesis. Toxicol Lett. 2000; 112-113:349-56.

126. Hein DW. Molecular genetics and function of NAT1 and NAT2: role in aromatic amine metabolism and carcinogenesis. Mutat Res. 2002;506-507:65-77.

127. Kanai Y, Manabe S, Wada O. In vitro and in vivo N-acetylation of carcinogenic glutamic acid pyrolysis products in humans. Carcinogenesis. 1988:9:2179-84

128. King RS, Teitel $\mathrm{CH}$, Kadlubar FF. In vitro bioactivation of N-hydroxy-2-aminoalpha-carboline. Carcinogenesis. 2000;21:1347-54.

129. Yuan ZX, Jha G, McGregor MA, King RS. Metabolites of the carcinogen 2amino-alpha-carboline formed in male Sprague-Dawley rats in vivo and in rat hepatocyte and human HepG2 cell incubates. Chem Res Toxicol. 2007; 20:497-503.

130. Bellamri M, Le Hegarat L, Turesky RJ, Langouet S. Metabolism of the tobacco carcinogen 2-amino-9H-pyrido[2,3-b]indole (AalphaC) in primary human hepatocytes. Chem Res Toxicol. 2017;30:657-68. 
131. Glatt H, Boeing H, Engelke CE, Ma L, Kuhlow A, Pabel U, et al. Human cytosolic sulphotransferases: genetics, characteristics, toxicological aspects. Mutat Res. 2001;482:27-40.

132. Teubner W, Meinl W, Florian S, Kretzschmar M, Glatt H. Identification and localization of soluble sulfotransferases in the human gastrointestinal tract. Biochem J. 2007:404:207-15.

133. Gamage N, Barnett A, Hempel N, Duggleby RG, Windmill KF, Martin JL, et al. Human sulfotransferases and their role in chemical metabolism. Toxicol Sci. 2006;90:5-22.

134. Blanchard RL, Freimuth RR, Buck J, Weinshilboum RM, Coughtrie MW. A proposed nomenclature system for the cytosolic sulfotransferase (SULT) superfamily. Pharmacogenetics. 2004;14:199-211.

135. Turesky RJ, Skipper PL, Tannenbaum SR, Coles B, Ketterer B. Sulfamate formation is a major route for detoxification of 2-amino-3-methylimidazo [4,5-f] quinoline in the rat. Carcinogenesis. 1986;7:1483-5.

136. Turesky RJ, Aeschbacher HU, Würzner HP, Skipper PL, Tannenbaum SR. Major routes of metabolism of the food-borne carcinogen 2-amino-3,8dimethylimidazo[4,5-f]quinoxaline in the rat. Carcinogenesis. 1988;9: 1043-8.

137. Ozawa S, Nagata K, Yamazoe Y, Kato R. Formation of 2-amino-3methylimidazo[4,5-f]quinoline- and 2-amino-3,8-dimethylimidazo[4,5f]quinoxaline-sulfamates by cDNA-expressed mammalian phenol sulfotransferases. Jpn J Cancer Res. 1995;86:264-9.

138. Alexander J, Heidenreich B, Reistad R, Holme JA. Metabolism of the food carcinogen 2-amino-1-methyl-6-phenylimidazo[4,5-b]pyridine (PhIP) in the rat and other rodents. New Jersey: Adamson RH, Gustafsson JA, Ito N, Nagao M, Sugimura T, Wakabayashi K, Yamazoe Y, Princeton Scientific Publishing Co., Inc; 1995. p. 59-68.

139. Guillemette C. Pharmacogenomics of human UDP-glucuronosyltransferase enzymes. Pharm J. 2003;3:136-58

140. Nagar S, Remmel RP. Uridine diphosphoglucuronosyltransferase pharmacogenetics and cancer. Oncogene. 2006;25:1659-72.

141. Styczynski PB, Blackmon RC, Groopman JD, Kensler TW. The direct glucuronidation of 2-amino-1-methyl-6-phenylimidazo[4,5-b]pyridine (PhIP) by human and rabbit liver microsomes. Chem Res Toxicol. 1993;6:846-51.

142. Tang Y, LeMaster DM, Nauwelaers G, Gu D, Langouet S, Turesky RJ. UDP-Glucuronosyltransferase-mediated metabolic activation of the tobacco carcinogen 2-amino-9H-pyrido[2,3-b]indole. J Biol Chem. 2012; 287:14960-72.

143. Malfatti MA, Felton JS. N-glucuronidation of 2-amino-1-methyl-6phenylimidazo[4,5-b]pyridine (PhIP) and N-hydroxy-PhIP by specific human UDP-glucuronosyltransferases. Carcinogenesis. 2001;22:1087-93.

144. Kulp KS, Knize MG, Fowler ND, Salmon CP, Felton JS. PhIP metabolites in human urine after consumption of well-cooked chicken. J Chromatogr B Anal Technol Biomed Life Sci. 2004;802:143-53.

145. Agus C, llett KF, Kadlubar FF, Minchin RF. Characterization of an ATPdependent pathway of activation for the heterocyclic amine carcinogen Nhydroxy-2-amino-3-methylimidazo[4,5-f]quinoline. Carcinogenesis. 2000;21: 1213-9.

146. Metry KJ, Zhao S, Neale JR, Doll MA, States JC, McGregor WG, et al. 2Amino-1-methyl-6-phenylimidazo[4,5-b]pyridine-induced DNA adducts and genotoxicity in Chinese hamster ovary $(\mathrm{CHO})$ cells expressing human CYP1A2 and rapid or slow acetylator N-acetyltransferase 2. Mol Carcinog. 2007:46:553-63

147. Bendaly J, Zhao S, Neale JR, Metry KJ, Doll MA, States JC, et al. 2-Amino-3,8dimethylimidazo-[4,5-f]quinoxaline-induced DNA adduct formation and mutagenesis in DNA repair-deficient Chinese hamster ovary cells expressing human cytochrome P4501A1 and rapid or slow acetylator $\mathrm{N}$ acetyltransferase 2. Cancer Epidemiol Biomark Prev. 2007;16:1503-9.

148. Turesky RJ, Bendaly J, Yasa I, Doll MA, Hein DW. The impact of NAT2 acetylator genotype on mutagenesis and DNA adducts from 2-amino-9Hpyrido[2,3-b]indole. Chem Res Toxicol. 2009;22:726-33.

149. Metry KJ, Neale JR, Doll MA, Howarth AL, States JC, McGregor WG, et al. Effect of rapid human $\mathrm{N}$-acetyltransferase 2 haplotype on DNA damage and mutagenesis induced by 2-amino-3-methylimidazo[4,5-f]quinoline (IQ) and 2-amino-3,8-dimethylimidazo[4,5-f]quinoxaline (MelQx). Mutat Res. 2010;684: 66-73.

150. Kazerani S, Novak M. Synthesis and characterization of the food-derived carcinogens 2-(Hydroxylamino)-alpha-carboline and 2-(Hydroxylamino)-3methyl-alpha-carboline. J Organomet Chem. 1998;63:895-7.
151. Nguyen TM, Novak M. Synthesis and decomposition of an ester derivative of the procarcinogen and promutagen, PhIP, 2-amino-1-methyl-6-phenyl$1 \mathrm{H}$-imidazo[4,5-b]pyridine: unusual nitrenium ion chemistry. J Organomet Chem. 2007;72:4698-706.

152. Frandsen $H$, Grivas $S$, Andersson R, Dragsted L, Larsen JC. Reaction of the $N^{2}$-acetoxy derivative of 2-amino-1-methyl-6-phenylimidazo[4,5-b]pyridine (PhIP) with 2'-deoxyguanosine and DNA. Synthesis and identification of $\mathrm{N}^{2}$ (2'-deoxyguanosin-8-yl)-PhIP. Carcinogenesis. 1992;13:629-35.

153. Peng L, Dasari S, Tabb DL, Turesky RJ. Mapping serum albumin adducts of the food-borne carcinogen 2-amino-1-methyl-6-phenylimidazo[4,5b]pyridine by data-dependent tandem mass spectrometry. Chem Res Toxicol. 2012;25:2179-93.

154. Nowell S, Ambrosone CB, Ozawa S, MacLeod SL, Mrackova G, Williams S, et al. Relationship of phenol sulfotransferase activity (SULT1A1) genotype to sulfotransferase phenotype in platelet cytosol. Pharmacogenetics. 2000;10: 789-97

155. Chevereau M, Glatt H, Zalko D, Cravedi JP, Audebert M. Role of human sulfotransferase $1 \mathrm{~A} 1$ and $\mathrm{N}$-acetyltransferase 2 in the metabolic activation of 16 heterocyclic amines and related heterocyclics to genotoxicants in recombinant V79 cells. Arch Toxicol. 2017;91:3175.

156. Glatt H, Pabel U, Meinl W, Frederiksen H, Frandsen H, Muckel E. Bioactivation of the heterocyclic aromatic amine 2-amino-3-methyl-9Hpyrido[2,3-b]indole (MeAalphaC) in recombinant test systems expressing human xenobiotic-metabolizing enzymes. Carcinogenesis. 2004;25:801-7.

157. Muckel E, Frandsen H, Glatt HR. Heterologous expression of human Nacetyltransferases 1 and 2 and sulfotransferase 1A1 in Salmonella typhimurium for mutagenicity testing of heterocyclic amines. Food Chem Toxicol. 2002:40:1063-8

158. Kaderlik KR, Mulder GJ, Turesky RJ, Lang NP, Teitel CH, Chiarelli MP, et al. Glucuronidation of $\mathrm{N}$-hydroxy heterocyclic amines by human and rat liver microsomes. Carcinogenesis. 1994;15:1695-701.

159. Girard H, Thibaudeau J, Court MH, Fortier LC, Villeneuve L, Caron P, et al. UGT1A1 polymorphisms are important determinants of dietary carcinogen detoxification in the liver. Hepatology. 2005;42:448-57.

160. Cai T, Yao L, Turesky RJ. Bioactivation of heterocyclic aromatic amines by UDP glucuronosyltransferases. Chem Res Toxicol. 2016;29:879-91.

161. Fede JM, Thakur AP, Gooderham NJ, Turesky RJ. Biomonitoring of 2-amino1-methyl-6-phenylimidazo[4,5-b]pyridine (PhIP) and its carcinogenic metabolites in urine. Chem Res Toxicol. 2009;22:1096-105.

162. Alexander J, Wallin H, Rossland OJ, Solberg KE, Holme JA, Becher G, et al. Formation of a glutathione conjugate and a semistable transportable glucuronide conjugate of $\mathrm{N}^{2}$-oxidized species of 2-amino-1-methyl-6phenylimidazo[4,5-b]pyridine (PhIP) in rat liver. Carcinogenesis. 1991;12: 2239-45.

163. Nowell SA, Massengill JS, Williams S, Radominska-Pandya A, Tephly TR, Cheng $Z$, et al. Glucuronidation of 2-hydroxyamino-1-methyl-6phenylimidazo[4,5-b]pyridine by human microsomal UDPglucuronosyltransferases: identification of specific UGT1A family isoforms involved. Carcinogenesis. 1999;20:1107-14.

164. Malfatti MA, Felton JS. Human UDP-glucuronosyltransferase $1 \mathrm{~A} 1$ is the primary enzyme responsible for the N-glucuronidation of N-hydroxy-PhIP in vitro. Chem Res Toxicol. 2004;17:1137-44.

165. Ritter JK. Roles of glucuronidation and UDP-glucuronosyltransferases in xenobiotic bioactivation reactions. Chem Biol Interact. 2000;129:171-93.

166. Irving CC. Glucuronide formation in the metabolism of N-substituted aryl compounds. Natl Cancer Inst Monogr. 1981;58:109-11.

167. Mulder GJ, Hinson JA, Gillette JR. Conversion of the N-Q-glucuronide and NO-sulfate conjugates of $\mathrm{N}$-hydroxyphenacetin to reactive intermediates. Biochem Pharmacol. 1978;27:1641-9.

168. Radomski JL, Hearn WL, Radomski T, Moreno H, Scott WE. Isolation of the glucuronic acid conjugate of N-hydroxy-4-aminobiphenyl from dog urine and its mutagenic activity. Cancer Res. 1977;37:1757-62.

169. Girard H, Butler LM, Villeneuve L, Millikan RC, Sinha R, Sandler RS, et al. UGT1A1 and UGT1A9 functional variants, meat intake, and colon cancer, among Caucasians and African-Americans. Mutat Res. 2008;644:56-63.

170. Hayes JD, Flanagan JU, Jowsey IR. Glutathione transferases. Annu Rev Pharmacol Toxicol. 2005:45:51-88

171. Mannervik B, Board PG, Hayes JD, Listowsky I, Pearson WR. Nomenclature for mammalian soluble glutathione transferases. Methods Enzymol. 2005; 401:1-8. 
172. Umemoto A, Grivas S, Yamaizumi Z, Sato S, Sugimura T. Non-enzymatic glutathione conjugation of 2-nitroso-6-methyldipyrido [1,2-a: 3',2'-d] imidazole (NO-Glu-P-1) in vitro: N-hydroxy-sulfonamide, a new binding form of aryInitroso compounds and thiols. Chem Biol Interact. 1988;68:57-69.

173. Saito K, Yamazoe Y, Kamataki T, Kato R. Activation and detoxication of Nhydroxy-Trp-P-2 by glutathione and glutathione transferases. Carcinogenesis. 1983;4:1551-7.

174. Lin DX, Meyer DJ, Ketterer B, Lang NP, Kadlubar FF. Effects of human and rat glutathione-S-transferase on the covalent binding of the $\mathrm{N}$-acetoxy derivatives of heterocyclic amine carcinogens in vitro: a possible mechanism of organ specificity in their carcinogensis. Cancer Res. 1994;54: 4920-6.

175. Nelson CP, Kidd LC, Sauvageot J, Isaacs WB, De Marzo AM, Groopman JD, et al. Protection against 2-hydroxyamino-1-methyl-6-phenylimidazo[4,5b]pyridine cytotoxicity and DNA adduct formation in human prostate by glutathione S-transferase P1. Cancer Res. 2001;61:103-9.

176. Kaderlik KR, Mulder GJ, Shaddock JG, Casciano DA, Teitel CH, Kadlubar FF. Effect of glutathione depletion and inhibition of glucuronidation and sulfation on 2-amino-1-methyl-6-phenylimidazo[4,5-b]pyridine (PhIP) metabolism, PhIP-DNA adduct formation and unscheduled DNA synthesis in primary rat hepatocytes. Carcinogenesis. 1994;15:1711-6.

177. Kaderlik KR, Minchin RF, Mulder GJ, Ilett KF, Daugaard-Jenson M, Teitel CH, et al. Metabolic activation pathway for the formation of DNA adducts of the carcinogen 2-amino-1-methyl-6-phenylimidazo[4,5-b]pyridine (PhIP) in rat extrahepatic tissues. Carcinogenesis. 1994;15:1703-9.

178. Coles BF, Morel F, Rauch C, Huber WW, Yang M, Teitel CH, et al. Effect of polymorphism in the human glutathione S-transferase A1 promoter on hepatic GSTA1 and GSTA2 expression. Pharmacogenetics. 2001;11:663-9.

179. Howie AF, Forrester LM, Glancey MJ, Schlager JJ, Powis G, Beckett GJ, et al. Glutathione S-transferase and glutathione peroxidase expression in normal and tumour human tissues. Carcinogenesis. 1990;11:451-8.

180. Turesky RJ, Rossi SC, Welti DH, Lay JJO, Kadlubar FF. Characterization of DNA adducts formed in vitro by reaction of $\mathrm{N}$-hydroxy-2-amino-3-methylimidazo [4,5-f] quinoline and N-hydroxy-2-amino-3,8-dimethylimidazo [4,5-f] quinoxaline at the C-8 and $\mathrm{N}^{2}$ atoms of guanine. Chem Res Toxicol. 1992;5: 479-90.

181. Lin D, Kaderlik KR, Turesky RJ, Miller DW, Lay JO Jr, Kadlubar FF. Identification of $\mathrm{N}$-(deoxyguanosin-8-yl)-2-amino-1-methyl-6phenylimidazo[4,5-b]pyridine as the major adduct formed by the foodborne carcinogen, 2-amino-1-methyl-6-phenylimidazo[4,5-b]pyridine, with DNA. Chem Res Toxicol. 1992;5:691-7.

182. Jamin EL, Arquier D, Canlet C, Rathahao E, Tulliez J, Debrauwer L. New insights in the formation of deoxynucleoside adducts with the heterocyclic aromatic amines PhIP and IQ by means of ion trap $\mathrm{MS}^{n}$ and accurate mass measurement of fragment ions. J Am Soc Mass Spectrom. 2007;18:2107-18.

183. Bessette EE, Goodenough AK, Langouet S, Yasa I, Kozekov ID, Spivack SD, et al. Screening for DNA adducts by data-dependent constant neutral losstriple stage mass spectrometry with a linear quadrupole ion trap mass spectrometer. Anal Chem. 2009;81:809-19.

184. Humphreys WG, Kadlubar FF, Guengerich FP. Mechanism of C8 alkylation of guanine residues by activated arylamines: evidence for initial adduct formation at the N7 position. Proc Natl Acad Sci U S A. 1992;89:8278-82.

185. Kohda K, Kawazoe Y, Minoura Y, Tada M. Separation and identification of N4-(guanosin-7-yl)-4-aminoquinoline 1-oxide, a novel nucleic acid adduct of carcinogen 4-nitroquinoline 1-oxide. Carcinogenesis. 1991;12:1523-5.

186. Kohda K, Tada M, Kasai H, Nishimura S, Kawazoe Y. Formation of 8hydroxyguanine residues in cellular DNA exposed to the carcinogen 4nitroquinoline 1-oxide. Biochem Biophys Res Commun. 1986;139:626-32.

187. Turesky RJ. DNA adducts of heterocyclic aromatic amines, arylazides and 4nitroquinoline 1-oxide. IARC Sci Publ. 1994;125:217-28.

188. Takamura-Enya T, Ishikawa S, Mochizuki M, Wakabayashi K. Chemical synthesis of 2'-deoxyguanosine-C8 adducts with heterocyclic amines: an application to synthesis of oligonucleotides site-specifically adducted with 2-amino-1-methyl-6-phenylimidazo[4,5-b]pyridine. Chem Res Toxicol. 2006 19:770-8.

189. Stover JS, Rizzo CJ. Synthesis of the $N^{2}$-deoxyguanosine adduct of the potent dietary mutagen IQ. Org Lett. 2004;6:4985-8.

190. Wang Z, Rizzo CJ. Synthesis of the C8-deoxyguanosine adduct of the food mutagen IQ. Org Lett. 2001;3:565-8.

191. Brown K, Guenther EA, Dingley KH, Cosman M, Harvey CA, Shields SJ, et al. Synthesis and spectroscopic characterization of site-specific 2-amino-1- methyl-6-phenylimidazo[4,5-b]pyridine oligodeoxyribonucleotide adducts. Nucleic Acids Res. 2001;29:1951-9.

192. Brown K, Hingerty BE, Guenther EA, Krishnan W, Broyde S, Turteltaub KW, et al. Solution structure of the 2-amino-1-methyl-6-phenylimidazo[4,5b]pyridine C8-deoxyguanosine adduct in duplex DNA. Proc Natl Acad Sci U S A. 2001;98:8507-12.

193. Patel DJ, Mao B, Gu Z, Hingerty BE, Gorin A, Basu AK, et al. Nuclear magnetic resonance solution structures of covalent aromatic amine-DNA adducts and their mutagenic relevance. Chem Res Toxicol. 1998;11:391-407.

194. Shibutani S, Fernandes A, Suzuki N, Zhou L, Johnson F, Grollman AP. Mutagenesis of the $\mathrm{N}$-(deoxyguanosin-8-yl)-2-amino-1-methyl-6phenylimidazo[4,5-b]pyridine DNA adduct in mammalian cells. Sequence context effects. J Biol Chem. 1999;274:27433-8.

195. Choi JY, Stover JS, Angel KC, Chowdhury G, Rizzo CJ, Guengerich FP. Biochemical basis of genotoxicity of heterocyclic arylamine food mutagens: human DNA polymerase eta selectively produces a two-base deletion in copying the N 2 -guanyl adduct of 2-amino-3-methylimidazo [4,5-f] quinoline but not the C8 adduct at the Narl G3 site. J Biol Chem. 2006;281: 25297-306.

196. Stover JS, Chowdhury G, Zang H, Guengerich FP, Rizzo CJ. Translesion synthesis past the C8- and N 2 -deoxyguanosine adducts of the dietary mutagen 2-amino-3-methylimidazo[4,5-f]quinoline in the Narl recognition sequence by prokaryotic DNA polymerases. Chem Res Toxicol. 2006;19: 1506-17.

197. Wang F, Elmquist CE, Stover JS, Rizzo CJ, Stone MP. DNA sequence modulates the conformation of the food mutagen 2-amino-3methylimidazo[4,5-f]quinoline in the recognition sequence of the Narl restriction enzyme. Biochemistry. 2007;46:8498-516.

198. Turteltaub KW, Vogel JS, Frantz CE, Shen N. Fate and distribution of 2amino-1-methyl-6-phenylimidazo[4,5-b]pyridine in mice at a human dietary equivalent dose. Cancer Res. 1992;52:4682-7.

199. Turteltaub KW, Dingley KH. Application of accelerated mass spectrometry (AMS) in DNA adduct quantification and identification. Toxicol Lett. 1998; 102-103:435-9.

200. Turteltaub KW, Dingley KH, Curtis KD, Malfatti MA, Turesky RJ, Garner RC, et al. Macromolecular adduct formation and metabolism of heterocyclic amines in humans and rodents at low doses. Cancer Lett. 1999;143:149-55.

201. Dingley KH, Curtis KD, Nowell S, Felton JS, Lang NP, Turteltaub KW. DNA and protein adduct formation in the colon and blood of humans after exposure to a dietary-relevant dose of 2-amino-1-methyl-6phenylimidazo[4,5-b]pyridine. Cancer Epidemiol Biomark Prev. 1999:8:50712.

202. Turesky RJ, Markovic J, Aeschlimann JM. Formation and differential removal of C-8 and N 2 -guanine adducts of the food carcinogen 2-amino-3methylimidazo [4,5- $\mathrm{f}$ ]quinoline in the liver, kidney, and colorectum of the rat. Chem Res Toxicol. 1996;9:397-402.

203. Snyderwine EG, Welti DH, Fay LB, Wurzner HP, Turesky RJ. Metabolism of the food mutagen 2-amino-3-methylimidazo [4,5-f] quinoline in nonhuman primates undergoing carcinogen bioassay. Chem Res Toxicol. 1992;5:843-51.

204. Totsuka Y, Fukutome K, Takahashi M, Takahashi S, Tada A, Sugimura T, et al. Presence of $\mathrm{N}^{2}$-(deoxyguanosin-8-yl)-2-amino-3,8-dimethylimidazo [4,5-f] quinoxaline (dG-C8-MelQx) in human tissues. Carcinogenesis. 1996;17:1029-34.

205. Friesen MD, Kaderlik K, Lin D, Garren L, Bartsch H, Lang NP, et al. Analysis of DNA adducts of 2-amino-1-methyl-6-phenylimidazo[4,5-b]pyridine in rat and human tissues by alkaline hydrolysis and gas chromatography/electron capture mass spectrometry: validation by comparison with ${ }^{32} \mathrm{P}$-postlabeling. Chem Res Toxicol. 1994;7:733-9.

206. Magagnotti C, Pastorelli R, Pozzi S, Andreoni B, Fanelli R, Airoldi L. Genetic polymorphisms and modulation of 2-amino-1-methyl-6-phenylimidazo[4,5b]pyridine (PhIP)-DNA adducts in human lymphocytes. Int J Cancer. 2003; 107:878-84

207. Gorlewska-Roberts K, Green B, Fares M, Ambrosone CB, Kadlubar FF. Carcinogen-DNA adducts in human breast epithelial cells. Environ Mol Mutagen. 2002;39:184-92.

208. Zhu J, Chang P, Bondy ML, Sahin AA, Singletary SE, Takahashi S, et al. Detection of 2-amino-1-methyl-6-phenylimidazo[4,5-b]pyridine-DNA adducts in normal breast tissues and risk of breast cancer. Cancer Epidemiol Biomark Prev. 2003;12:830-7.

209. Zhu J, Rashid A, Cleary K, Abbruzzese JL, Friess H, Takahashi S, et al. Detection of 2-amino-1-methyl-6-phenylimidazo[4,5-b]pyridine (PhIP)-DNA adducts in human pancreatic tissues. Biomarkers. 2006;11:319-28. 
210. Tang D, Liu JJ, Rundle A, Neslund-Dudas C, Savera AT, Bock CH, et al. Grilled meat consumption and PhIP-DNA adducts in prostate carcinogenesis. Cancer Epidemiol Biomark Prev. 2007;16:803-8.

211. Lightfoot TJ, Coxhead JM, Cupid BC, Nicholson S, Garner RC. Analysis of DNA adducts by accelerator mass spectrometry in human breast tissue after administration of 2-amino-1-methyl-6-phenylimidazo[4,5-b]pyridine and benzo [a]pyrene. Mutat Res. 2000;472:119-27.

212. Gu D, Turesky RJ, Tao Y, Langouet SA, Nauwelaers GC, Yuan JM, et al. DNA adducts of 2-amino-1-methyl-6-phenylimidazo[4,5-b]pyridine and 4aminobiphenyl are infrequently detected in human mammary tissue by liquid chromatography/tandem mass spectrometry. Carcinogenesis. 2012;33:124-30.

213. Bellamri M, Xiao S, Murugan P, Weight CJ, Turesky RJ. Metabolic activation of the cooked meat carcinogen 2-amino-1-methyl-6-phenylimidazo[4,5b]pyridine in human prostate. Toxicol Sci. 2018;163:543-56.

214. Xiao S, Guo J, Yun BH, Villalta PW, Krishna S, Tejpaul R, et al. Biomonitoring DNA adducts of cooked meat carcinogens in human prostate by nano liquid chromatography-high resolution tandem mass spectrometry: identification of 2-amino-1-methyl-6-phenylimidazo[4,5-b]pyridine DNA adduct. Anal Chem. 2016;88:12508-15.

215. Tang D, Liu JJ, Bock CH, Neslund-Dudas C, Rundle A, Savera AT, et al. Racial differences in clinical and pathological associations with PhIP-DNA adducts in prostate. Int J Cancer. 2007;121:1319-24.

216. Yun BH, Xiao S, Yao L, Krishnamachari S, Rosenquist TA, Dickman KG, et al. A rapid throughput method to extract DNA from formalin-fixed paraffinembedded tissues for biomonitoring carcinogenic DNA adducts. Chem Res Toxicol. 2017;30:2130-9.

217. Skipper PL, Tannenbaum SR. Protein adducts in the molecular dosimetry of chemical carcinogens. Carcinogenesis. 1990;11:507-18.

218. Tannenbaum SR, Skipper PL, Wishnok JS, Stillwell WG, Day BW, Taghizadeh K. Characterization of various classes of protein adducts. Environ Health Perspect. 1993;99:51-5.

219. Scholl PF, Turner PC, Sutcliffe AE, Sylla A, Diallo MS, Friesen MD, et al. Quantitative comparison of aflatoxin B1 serum albumin adducts in humans by isotope dilution mass spectrometry and ELISA. Cancer Epidemiol Biomark Prev. 2006;15:823-6.

220. Sabbioni G, Turesky RJ. Biomonitoring human albumin adducts: the past, the present, and the future. Chem Res Toxicol. 2017;30:332-66.

221. Rappaport SM, Li H, Grigoryan H, Funk WE, Williams ER. Adductomics: characterizing exposures to reactive electrophiles. Toxicol Lett. 2012;213: 83-90.

222. Sabbioni G. Hemoglobin adducts and urinary metabolites of arylamines and nitroarenes. Chem Res Toxicol. 2017;30:1733-66.

223. Carlsson H, Tornqvist M. Strategy for identifying unknown hemoglobin adducts using adductome LC-MS/MS data: identification of adducts corresponding to acrylic acid, glyoxal, methylglyoxal, and 1-octen-3-one. Food Chem Toxicol. 2016;92:94-103.

224. Tornqvist M, Fred C, Haglund J, Helleberg H, Paulsson B, Rydberg P. Protein adducts: quantitative and qualitative aspects of their formation, analysis and applications. J Chromatogr B Anal Technol Biomed Life Sci. 2002;778:279-308.

225. Beland FA, Kadlubar FF. Metabolic activation and DNA adducts of aromatic amines and nitroaromatic hydrocarbons. Heidelberg: Cooper CS, Grover PL, Springer-Verlag; 1990. p. 267-325.

226. Pathak KV, Chiu TL, Amin EA, Turesky RJ. Methemoglobin formation and characterization of hemoglobin adducts of carcinogenic aromatic amines and heterocyclic aromatic amines. Chem Res Toxicol. 2016;29:255-69.

227. Ringe D, Turesky RJ, Skipper PL, Tannenbaum SR. Structure of the single stable hemoglobin adduct formed by 4-aminobiphenyl in vivo. Chem Res Toxicol. 1988;1:22-4.

228. Bryant MS, Vineis P, Skipper PL, Tannenbaum SR. Hemoglobin adducts of aromatic amines: associations with smoking status and type of tobacco. Proc Natl Acad Sci U S A. 1988:85:9788-91.

229. Dingley KH, Freeman SP, Nelson DO, Garner RC, Turteltaub KW. Covalent binding of 2-amino-3,8-dimethylimidazo[4,5-f]quinoxaline to albumin and hemoglobin at environmentally relevant doses. Comparison of human subjects and F344 rats. Drug Metab Dispos. 1998;26:825-8.

230. Turesky RJ, Skipper PL, Tannenbaum SR. Binding of 2-amino-3-methylimidazo $[4,5-f]$ quinoline to hemoglobin and albumin in vivo in the rat. Identification of an adduct suitable for dosimetry. Carcinogenesis. 1987;8:1537-42.

231. Zhang L, Ashley DL, Watson CH. Quantitative analysis of six heterocyclic aromatic amines in mainstream cigarette smoke condensate using isotope dilution liquid chromatography-electrospray ionization tandem mass spectrometry. Nicotine Tob Res. 2011;13:120-6.

232. Patrianakos C, Hoffmann D. Chemical studies on tobacco smoke LXIV. On the analysis of aromatic amines in cigarette smoke. J Anal Toxicol. 1979;3: $150-4$.

233. Zha Q, Qian NX, Moldoveanu SC. Analysis of polycyclic aromatic hydrocarbons in the particulate phase of cigarette smoke using a gas chromatographic-high-resolution mass spectrometric technique. J Chromatogr Sci. 2002;40:403-8.

234. Cai T, Bellamri M, Ming X, Koh WP, Yu MC, Turesky RJ. Quantification of hemoglobin and white blood cell DNA adducts of the tobacco carcinogens 2-amino-9H-pyrido[2,3-b]indole and 4-aminobiphenyl formed in humans by nanoflow liquid chromatography/ion trap multistage mass spectrometry. Chem Res Toxicol. 2017;30:1333-43.

235. Raza H, King RS, Squires RB, Guengerich FP, Miller DW, Freeman JP, et al. Metabolism of 2-amino-alpha-carboline. A food-borne heterocyclic amine mutagen and carcinogen by human and rodent liver microsomes and by human cytochrome P4501A2. Drug MetabDispos. 1996;24:395-400.

236. Nauwelaers G, Bessette EE, Gu D, Tang Y, Rageul J, Fessard V, et al. DNA adduct formation of 4-aminobiphenyl and heterocyclic aromatic amines in human hepatocytes. Chem Res Toxicol. 2011;24:913-25.

237. Bryant MS, Skipper PL, Tannenbaum SR, Maclure M. Hemoglobin adducts of 4-aminobiphenyl in smokers and nonsmokers. Cancer Res. 1987;47:602-8.

238. Peters T Jr. Serum albumin. Adv Protein Chem. 1985;37:161-245.

239. Peters T Jr. All about albumin. Biochemistry, genetics, and medical applications. San Diego: Academic Press; 1996.

240. Sabbioni G, Skipper PL, Buchi G, Tannenbaum SR. Isolation and characterization of the major serum albumin adduct formed by aflatoxin B1 in vivo in rats. Carcinogenesis. 1987;8:819-24.

241. Wild CP, Hudson GJ, Sabbioni G, Chapot B, Hall AJ, Wogan GN, et al. Dietary intake of aflatoxins and the level of albumin-bound aflatoxin in peripheral blood in The Gambia, West Africa. Cancer Epidemiol Biomark Prev. 1992;1: 229-34.

242. Beck JL, Ambahera S, Yong SR, Sheil MM, de JJ, Ralph SF. Direct observation of covalent adducts with Cys34 of human serum albumin using mass spectrometry. Anal Biochem. 2004;325:326-36.

243. Grigoryan H, Edmands WM, Lu SS, Yano Y, Regazzoni L, lavarone AT, et al. An adductomics pipeline for untargeted analysis of modifications to Cys34 of human serum albumin. Anal Chem. 2016.

244. Grigoryan H, Li H, lavarone AT, Williams ER, Rappaport SM. Cys34 adducts of reactive oxygen species in human serum albumin. Chem Res Toxicol. 2012; 25:1633-42

245. Carter DC, Ho JX. Structure of serum albumin. Adv Protein Chem. 1994;45: 153-203.

246. Stewart AJ, Blindauer CA, Berezenko S, Sleep D, Tooth D, Sadler PJ. Role of Tyr84 in controlling the reactivity of Cys34 of human albumin. FEBS J. 2005; 272:353-62.

247. Christodoulou J, Sadler PJ. 1H NMR of albumin in human blood plasma: drug binding and redox reactions at Cys34. FEBS Lett. 1995;376:1-5.

248. Aldini G, Regazzoni L, Orioli M, Rimoldi I, Facino RM, Carini M. A tandem MS precursor-ion scan approach to identify variable covalent modification of albumin Cys34: a new tool for studying vascular carbonylation. J Mass Spectrom. 2008:43:1470-81.

249. Chepanoske CL, Brown K, Turteltaub KW, Dingley KH. Characterization of a peptide adduct formed by $\mathrm{N}$-acetoxy-2-amino-1-methyl-6phenylimidazo[4,5-b]pyridine (PhIP), a reactive intermediate of the food carcinogen PhIP. Food Chem Toxicol. 2004;42:1367-72.

250. Reistad R, Frandsen $H$, Grivas S, Alexander J. In vitro formation and degradation of 2-amino-1-methyl-6-phenylimidazo[4,5-b]pyridine (PhIP) protein adducts. Carcinogenesis. 1994;15:2547-52.

251. Magagnotti C, Orsi F, Bagnati R, Celli N, Rotilio D, Fanelli R, et al. Effect of diet on serum albumin and hemoglobin adducts of 2-amino-1-methyl-6phenylimidazo[4,5-b]pyridine (PhIP) in humans. Int J Cancer. 2000;88:1-6.

252. Bellamri M, Wang Y, Yonemori K, White KK, Wilkens LR, Le Marchand L, et al. Biomonitoring an albumin adduct of the cooked meat carcinogen 2-amino1-methyl-6-phenylimidazo[4,5-b]pyridine in humans. Carcinogenesis. 2018; 39:1455-62.

253. Wang Y, Villalta PW, Peng L, Dingley K, Malfatti MA, Turteltaub KW, et al. Mass spectrometric characterization of an acid-labile adduct formed with 2amino-1-methyl-6-phenylimidazo[4,5-b]pyridine and albumin in humans. Chem Res Toxicol. 2017;30:705-14. 
254. Sheng J, Wang Y, Turesky RJ, Kluetzman K, Zhang QY, Ding X. Novel transgenic mouse model for studying human serum albumin as a biomarker of carcinogenic exposure. Chem Res Toxicol. 2016;29:797-809.

255. Wang Y, Peng L, Bellamri M, Langouet S, Turesky RJ. Mass spectrometric characterization of human serum albumin adducts formed with $\mathrm{N}$-oxidized metabolites of 2-amino-1-methylphenylimidazo[4,5-b]pyridine in human plasma and hepatocytes. Chem Res Toxicol. 2015;28:1045-59.

256. Peng L, Turesky RJ. Optimizing proteolytic digestion conditions for the analysis of serum albumin adducts of 2-amino-1-methyl-6phenylimidazo[4,5-b]pyridine, a potential human carcinogen formed in cooked meat. J Proteome. 2014;103:267-78.

257. Turesky RJ, White KK, Wilkens LR, Le Marchand L. Caffeine cytochrome P450 1A2 metabolic phenotype does not predict the metabolism of heterocyclic aromatic amines in humans. Chem Res Toxicol. 2015;28:1603-15.

258. Sinha R, Cross A, Curtin J, Zimmerman T, McNutt S, Risch A, et al. Development of a food frequency questionnaire module and databases for compounds in cooked and processed meats. Mol Nutr Food Res. 2005:49: 648-55.

259. Iwasaki M, Mukai $T$, Takachi $R$, Ishihara J, Totsuka $Y$, Tsugane S. Validity of a self-administered food frequency questionnaire in the estimation of heterocyclic aromatic amines. Cancer Causes Control. 2014;25:1015-28.

260. Appenzeller BM, Tsatsakis AM. Hair analysis for biomonitoring of environmental and occupational exposure to organic pollutants: state of the art, critical review and future needs. Toxicol Lett. 2012;210:119-40.

261. Vincenti M, Salomone A, Gerace E, Pirro V. Application of mass spectrometry to hair analysis for forensic toxicological investigations. Mass Spectrom Rev. 2013:32:312-32.

262. Strano-Rossi S, Castrignano E, Anzillotti L, Odoardi S, De-Giorgio F, Bermejo $A$, et al. Screening for exogenous androgen anabolic steroids in human hair by liquid chromatography/orbitrap-high resolution mass spectrometry. Anal Chim Acta. 2013;793:61-71.

263. Bessette EE, Yasa I, Dunbar D, Wilkens LR, Marchand LL, Turesky RJ. Biomonitoring of carcinogenic heterocyclic aromatic amines in hair: a validation study. Chem Res Toxicol. 2009;22:1454-63.

264. Alexander J, Reistad R, Hegstad S, Frandsen H, Ingebrigtsen K, Paulsen JE, et al. Biomarkers of exposure to heterocyclic amines: approaches to improve the exposure assessment. Food Chem Toxicol. 2002;40:1131-7.

265. Hegstad S, Reistad R, Haug LS, Alexander J. Eumelanin is a major determinant for 2-amino-1-methyl-6-phenylimidazo[4,5-b]pyridine (PhIP) incorporation into hair of mice. Pharmacol Toxicol. 2002;90:333-7.

266. Gu D, Neuman ZL, Modiano JF, Turesky RJ. Biomonitoring the cooked meat carcinogen 2-amino-1-methyl-6-phenylimidazo[4,5-b]pyridine in canine fur. J Agric Food Chem. 2012;60:9371-5.

267. Turesky RJ, Liu L, Gu D, Yonemori KM, White KK, Wilkens LR, et al. Biomonitoring the cooked meat carcinogen 2-amino-1-methyl-6phenylimidazo[4,5-b]pyridine in hair: impact of exposure, hair pigmentation, and cytochrome P450 1A2 phenotype. Cancer Epidemiol Biomark Prev. 2013;22:356-64.

268. Le Marchand L, Yonemori K, White KK, Franke AA, Wilkens LR, Turesky RJ. Dose validation of PhIP hair level as a biomarker of heterocyclic aromatic amines exposure: a feeding study. Carcinogenesis. 2016;37:685-91.

269. Keating GA, Bogen KT. Estimates of heterocyclic amine intake in the US population. J Chromatogr B Anal Technol Biomed Life Sci. 2004:802:127-33.

270. Torre LA, Siegel RL, Ward EM, Jemal A. Global cancer incidence and mortality rates and trends--an update. Cancer Epidemiol Biomark Prev. 2016; 25:16-27.

271. Gann PH. Risk factors for prostate cancer. Rev Urol. 2002;4(Suppl 5):S3-S10.

272. Wilkens LR, Kolonel LN. Migrant studies. New York: Schottenfeld D, Fraumeni JF, Jr., Oxford University Press; 2006. p. 189-201.

273. Perdana NR, Mochtar CA, Umbas R, Hamid AR. The risk factors of prostate cancer and its prevention: a literature review. Acta Med Indones. 2016;48:228-38.

274. Bostwick DG, Burke HB, Djakiew D, Euling S, Ho SM, Landolph J, et al. Human prostate cancer risk factors. Cancer. 2004;101:2371-490.

275. Knize MG, Felton JS. Formation and human risk of carcinogenic heterocyclic amines formed from natural precursors in meat. Nutr Rev. 2005;63:158-65.

276. Cross AJ, Leitzmann MF, Gail MH, Hollenbeck AR, Schatzkin A, Sinha R. A prospective study of red and processed meat intake in relation to cancer risk. PLoSMed. 2007:4:e325.

277. Alexander DD, Morimoto LM, Mink PJ, Cushing CA. A review and metaanalysis of red and processed meat consumption and breast cancer. Nutr Res Rev. 2010;23:349-65.
278. Cross AJ, Peters U, Kirsh VA, Andriole GL, Reding D, Hayes RB, et al. A prospective study of meat and meat mutagens and prostate cancer risk Cancer Res. 2005;65:11779-84.

279. Joshi AD, Corral R, Catsburg C, Lewinger JP, Koo J, John EM, et al. Red meat and poultry, cooking practices, genetic susceptibility and risk of prostate cancer: results from a multiethnic case-control study. Carcinogenesis. 2012; 33:2108-18.

280. Koutros S, Cross AJ, Sandler DP, Hoppin JA, Ma X, Zheng T, et al. Meat and meat mutagens and risk of prostate cancer in the agricultural health study. Cancer Epidemiol Biomark Prev. 2008;17:80-7.

281. Rohrmann S, Nimptsch K, Sinha R, Willett WC, Giovannucci EL, Platz EA, et al. Intake of meat mutagens and risk of prostate cancer in a cohort of $U$. S. health professionals. Cancer Epidemiol Biomark Prev. 2015;24:1557-63.

282. Phillips DH. Polycyclic aromatic hydrocarbons in the diet. Mutat Res. 1999; 443:139-47.

283. Poirier MC. Chemical-induced DNA damage and human cancer risk. Discov Med. 2012;14:283-8.

284. Pratt MM, John K, MacLean AB, Afework S, Phillips DH, Poirier MC. Polycyclic aromatic hydrocarbon (PAH) exposure and DNA adduct semi-quantitation in archived human tissues. Int J Environ Res Public Health. 2011;8:2675-91.

285. Koutros S, Berndt SI, Sinha R, Ma X, Chatterjee N, Alavanja MC, et al. Xenobiotic metabolizing gene variants, dietary heterocyclic amine intake, and risk of prostate cancer. Cancer Res. 2009;69:1877-84.

286. Sinha R, Park Y, Graubard Bl, Leitzmann MF, Hollenbeck A, Schatzkin A, et al. Meat and meat-related compounds and risk of prostate cancer in a large prospective cohort study in the United States. Am J Epidemiol. 2009;170: 1165-77.

287. Turteltaub KW, Felton JS, Gledhill BL, Vogel JS, Southon JR, Caffee MW, et al. Accelerator mass spectrometry in biomedical dosimetry: relationship between low-level exposure and covalent binding of heterocyclic amine carcinogens to DNA. Proc Natl Acad Sci U S A. 1990;87:5288-92.

288. Turteltaub KW, Mauthe RJ, Dingley KH, Vogel JS, Frantz CE, Garner RC, et al. MelQx-DNA adduct formation in rodent and human tissues at low doses. Mutat Res. 1997;376:243-52.

289. Bogen KT, Keating GA, Chan JM, Paine LJ, Simms EL, Nelson DO, et al. Highly elevated PSA and dietary PhIP intake in a prospective clinic-based study among African Americans. Prostate Cancer Prostatic Dis. 2007;10:261-9.

290. Bogen KT, Keating GA. U.S. dietary exposures to heterocyclic amines. JExpoAnalEnvironEpidemiol. 2001;11:155-68.

291. Wang CY, Debiec-Rychter M, Schut HA, Morse P, Jones RF, Archer C, et al. $\mathrm{N}$-Acetyltransferase expression and DNA binding of $\mathrm{N}$-hydroxyheterocyclic amines in human prostate epithelium. Carcinogenesis. 1999;20:1591-5.

292. Williams JA, Martin FL, Muir GH, Hewer A, Grover PL, Phillips DH. Metabolic activation of carcinogens and expression of various cytochromes P450 in human prostate tissue. Carcinogenesis. 2000;21:1683-9.

293. Kooiman GG, Martin FL, Williams JA, Grover PL, Phillips DH, Muir GH. The influence of dietary and environmental factors on prostate cancer risk. Prostate Cancer Prostatic Dis. 2000;3:256-8.

294. Martin FL, Cole KJ, Muir GH, Kooiman GG, Williams JA, Sherwood RA, et al. Primary cultures of prostate cells and their ability to activate carcinogens. Prostate Cancer Prostatic Dis. 2002;5:96-104

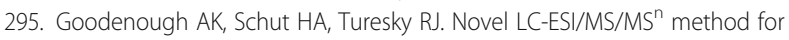
the characterization and quantification of 2'-deoxyguanosine adducts of the dietary carcinogen 2-amino-1-methyl-6-phenylimidazo[4,5-b]pyridine by 2-D linear quadrupole ion trap mass spectrometry. Chem Res Toxicol. 2007;20: 263-76

296. Nagao M. Mutagenicity. Chichester: Nagao M, Sugimura T, John Wiley \& Sons Ltd; 2000. p. 163-95.

297. Stuart GR, Thorleifson E, Okochi E, de Boer JG, Ushijima T, Nagao M, et al. Interpretation of mutational spectra from different genes: analyses of PhIPinduced mutational specificity in the lacl and cll transgenes from colon of big blue rats. Mutat Res. 2000;452:101-21.

298. Alexandrov LB, Kim J, Haradhvala NJ, Huang MN, Tian Ng AW, Wu Y, et al. The repertoire of mutational signatures in human cancer. Nature. 2020;578:94-101.

299. Kucab JE, Zou X, Morganella S, Joel M, Nanda AS, Nagy E, et al. A compendium of mutational signatures of environmental agents. Cell. 2019; 177:821-36 e16.

300. Glass-Holmes M, Aguilar BJ, Gragg RD, Darling-Reed S, Goodman CB. Characterization of 2-amino-1-methyl-6-phenylimidazo[4,5-b]pyridine at androgen receptor: mechanistic support for its role in prostate cancer. Am J Cancer Res. 2015;5:191-200. 
301. Creton SK, Zhu H, Gooderham NJ. The cooked meat carcinogen 2-amino-1methyl-6-phenylimidazo[4,5-b]pyridine activates the extracellular signal regulated kinase mitogen-activated protein kinase pathway. Cancer Res. 2007;67:11455-62.

302. Bellamri M, Brown C, Murugan P, Weight CJ, Turesky RJ. Biological effects of the cooked meat carcinogen PhIP in human prostate cancer American Chemical Society Fall National Meeting, 2019, San Diego, CA. https:/www.a cs.org/content/dam/acsorg/meetings/national-meetings/fall-2019/fall_2019_ national_meeting_draft-technical-program.pdf.

303. Tan MH, Li J, Xu HE, Melcher K, Yong EL. Androgen receptor: structure, role in prostate cancer and drug discovery. Acta Pharmacol Sin. 2015;36:3-23.

304. Nieminen AL, Byrne AM, Herman B, Lemasters JJ. Mitochondrial permeability transition in hepatocytes induced by t-BuOOH: NAD(P) H and reactive oxygen species. Am J Phys. 1997;272:C1286-94.

305. Asantewaa G, Harris IS. Glutathione and its precursors in cancer. Curr Opin Biotechnol. 2021;68:292-9.

306. Paschos A, Pandya R, Duivenvoorden WC, Pinthus JH. Oxidative stress in prostate cancer: changing research concepts towards a novel paradigm for prevention and therapeutics. Prostate Cancer Prostatic Dis. 2013;16:217-25.

307. Pfeifer GP. Defining driver DNA methylation changes in human cancer. Int J Mol Sci. 2018;19(4):1166. https://doi.org/10.3390/ijms19041166.

308. Li S, Park Y, Duraisingham S, Strobel FH, Khan N, Soltow QA, et al. Predicting network activity from high throughput metabolomics. PLoS Comput Biol. 2013;9:e1003123.

309. Xia J, Wishart DS. Using metaboAnalyst 3.0 for comprehensive metabolomics data analysis. Curr Protoc Bioinformatics. 2016:55:14 10 1-14 1091.

310. Rinschen MM, Ivanisevic J, Giera M, Siuzdak G. Identification of bioactive metabolites using activity metabolomics. Nat Rev Mol Cell Biol. 2019;20: 353-67.

311. Dubey V, Owusu-Apenten R. Curcumin restores glutathione-S-transferase activity for LNCaP prostate cancer cells. Pure Appl Chem. 2014;2:61-72.

312. Jividen K, Kedzierska KZ, Yang CS, Szlachta K, Ratan A, Paschal BM. Genomic analysis of DNA repair genes and androgen signaling in prostate cancer. BMC Cancer. 2018;18:960.

\section{Publisher's Note}

Springer Nature remains neutral with regard to jurisdictional claims in published maps and institutional affiliations.

Ready to submit your research? Choose BMC and benefit from:

- fast, convenient online submission

- thorough peer review by experienced researchers in your field

- rapid publication on acceptance

- support for research data, including large and complex data types

- gold Open Access which fosters wider collaboration and increased citations

- maximum visibility for your research: over $100 \mathrm{M}$ website views per year

At BMC, research is always in progress.

Learn more biomedcentral.com/submissions 